\title{
23. APTIAN TO CENOMANIAN DINOFLAGELLATE CYSTS FROM THE MAZAGAN PLATEAU, NORTHWEST AFRICA (SITES 545 AND 547, DEEP SEA DRILLING PROJECT LEG 79) ${ }^{1}$
}

\author{
Raimond Below, Institut für Paläontologie, Universität Bonn²
}

\begin{abstract}
Eighty-eight samples of Aptian to lower Cenomanian sediments of Sites 545 and 547, DSDP Leg 79, from the Mazagan Plateau area (offshore Northwest Africa) were analyzed for palynomorphs. The very rich dinoflagellate cyst assemblages make it possible to narrow shipboard age determinations and to correlate Sites 545 and 547. The distribution of 174 dinoflagellate cyst taxa is tabulated in this study and the biostratigraphic value of selected dinoflagellate cysts is discussed. Additional taxonomic remarks are made about some species. The new dinoflagellate cyst species Aptea almohadensis, Occisucysta hinzii, O. mazaganensis, and the subspecies Maghrebinia perforata (Clarke and Verdier, 1967) Below, 1981 ssp. mirabilis are described.
\end{abstract}

\section{INTRODUCTION}

Sites 544 to 547 were drilled in the Mazagan Plateau area of the Moroccan Atlantic continental slope during DSDP Leg 79. Of these, Sites 545 and 547 were chosen for biostratigraphic analysis of mid-Cretaceous dinoflagellate cyst assemblages.

Site 545, at the northwestern foot of the Mazagan Plateau slope, consists of $701 \mathrm{~m}$ of Jurassic to Quaternary sediment. For this palynological study, $278 \mathrm{~m}$ of green, carbonaceous claystone with a few meters of dolomitized chalk at the base are of interest. The age was determined by shipboard scientists as early late Aptian to middle or late Cenomanian. These strata rest unconformably on Jurassic carbonates and are separated by a further unconformity from the overlying Neogene chalks.

Site $547,14 \mathrm{~km}$ north-northeast of Site 545 , is situated on the northeastern slope of a basement horst. Holes 547A and 547B penetrate a total of $1030 \mathrm{~m}$ of Jurassic to Quaternary sediment. The samples for this study were taken from a 351-m-thick section of Albian to Cenomanian carbonaceous clay- and mudstones. This interval is separated from the underlying Jurassic limestones by a major hiatus, and from overlying debris flows, reworked during the Late Cretaceous and Paleocene, by an unconformity.

A total of 88 samples were prepared using common palynological techniques. In addition to various palynomorphs such as pollen and spores, acritarchs, scolecodonts, phycomycetes, "micro-foraminifers", wood fragments, and cuticula, all samples yielded rich dinoflagellate cyst assemblages, with many individuals and often very high species diversity. Preservation of the cysts is very good, except for a few reworked specimens.

Analysis of these dinoflagellate cyst assemblages has made possible the detailed determination of sediment ages, subdivision of the mid-Cretaceous sequence, and

\footnotetext{
${ }^{1}$ Hinz, K., Winterer, E. L., et al., Init. Repts. DSDP, 79: Washington (U.S. Govt. Printing Office).

2 Address: Institut für Palãontologie, Rheinische Friedrich-Wilhelms Universität Bonn, Nussallee 8, D-5300 Bonn, Federal Republic of Germany.
}

correlation of Site 547 with Site 545 . The results will be discussed in the biostratigraphic section of this chapter. Another section deals with dinoflagellate cyst taxonomy; it includes short remarks about selected species and descriptions of four new taxa.

\section{BIOSTRATIGRAPHY}

Because reliable, detailed, and universally valid dinoflagellate cyst zones for the mid-Cretaceous Period are not yet formalized, age determination is based on comparison with dinoflagellate cyst assemblages known from the neighboring, stratigraphically well-dated sections of Site 370 (Williams, 1978) and Moroccan onshore sections (Below, 1981; Below, 1982a, 1982b).

Site $545\left(33^{\circ} 39.86^{\prime} \mathbf{N}\right.$; $9^{\circ} 21.88^{\prime} \mathrm{W}$; water depth $3142 \mathrm{~m}$ )

A total of $278 \mathrm{~m}$ of mid-Cretaceous sediment was drilled, extending from Core 56 to Core 27. The basal 10 $\mathrm{m}$ consist of yellow grey dolomitic chalks resting immediately upon the Jurassic/mid-Cretaceous unconformity. These strata were dated as early late Aptian by shipboard paleontologists (shore-based study). The series continues with a monotonous interval of carbonaceous claystones with a few layers of clay pebbles in Cores 40 , 35 , and 34 . Within this sequence, the following shipboard age determinations were proposed, using foraminifers and nannofossils: Core 56, early Aptian (?late Barremian); Cores 55 to 44, late Aptian; Cores 44 to 37, late Albian, with problematic existence of early Albian equivalents; Cores 36 to 34, early(?) Cenomanian; Cores 34 to 33, middle(?) Cenomanian; Cores 33 to 27, late Cenomanian. These ages have subsequently been further refined with shore-based study (see chapters by Leckie and Wiegand, this volume). The mid-Cretaceous/Neogene unconformity is located within Core 27.

\section{Analysis}

From Hole 545, 39 samples were collected: 3 in $11 \mathrm{~m}$ of the ?Barremian-Aptian sequence; 18 in $110 \mathrm{~m}$ of upper Aptian sediments; 12 in $70 \mathrm{~m}$ of the upper Albian interval, and 6 in $87 \mathrm{~m}$ of Cenomanian age. The distri- 


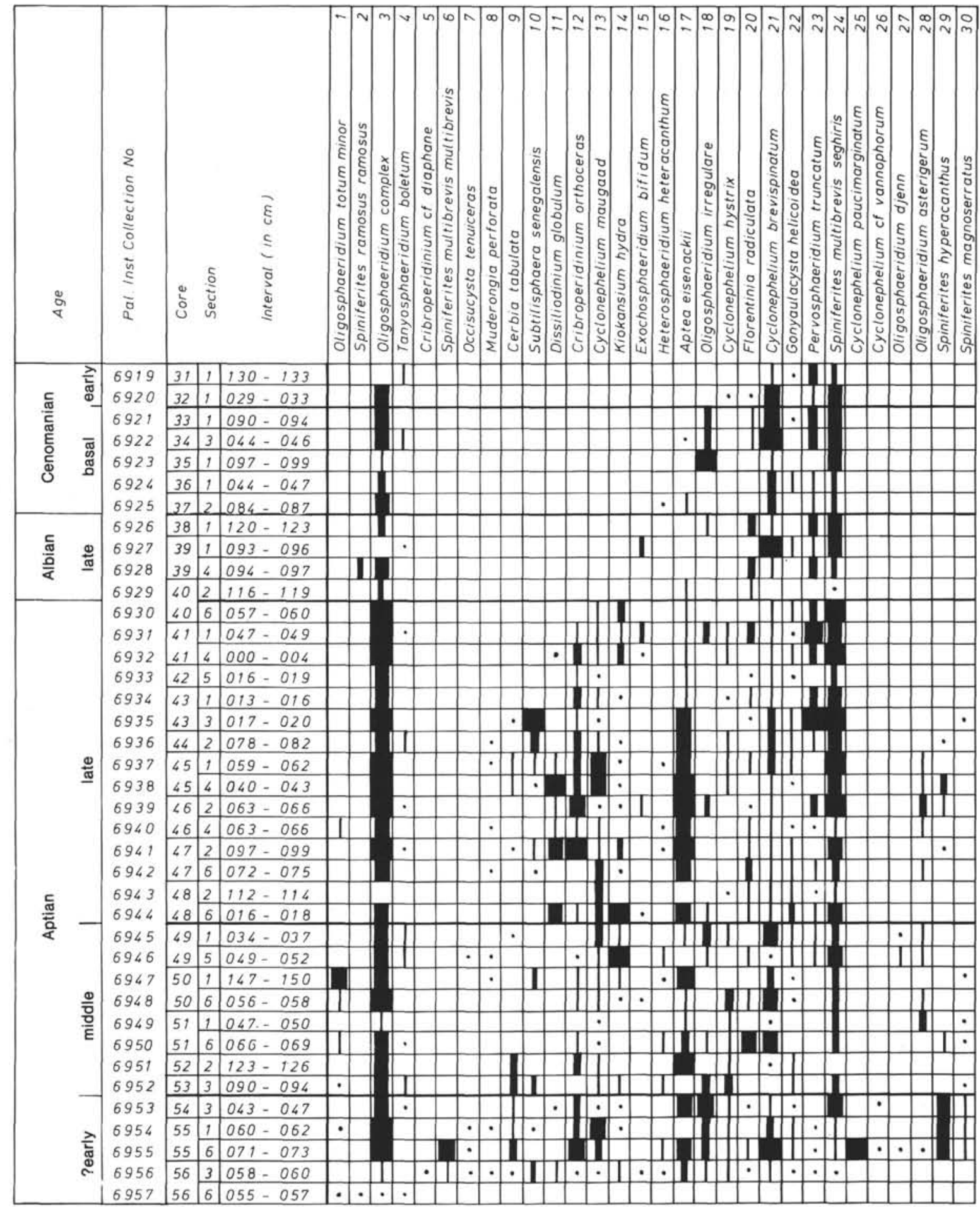

Figure 1. Distribution of dinoflagellate cysts in the mid-Cretaceous of Hole 545.

bution of the 160 taxa recorded within these samples is shown in Figure 1.

Many species are present throughout the whole Aptian to Cenomanian sequence. There are also a number of longer-ranging dinoflagellate cysts. Many of these taxa dominate in most assemblages, having more than 100 specimens: for example, Cyclonephelium brevispinatum, Florentinia radiculata, F. mantellii, Gonyaulacysta heli- coidea, Odontochitina operculata, Oligosphaeridium complex, O. irregulare, Spiniferites ancoriferus ssp. ancoriferus. Other species show maximum frequency in limited intervals, which can be of stratigraphic value: Aptea eisenackii, Pervosphaeridium truncatum, and Trichodinium castanea. Some species, in contrast, are found to dominate only during a very short stratigraphic interval: Aptea almohadensis, Chlamydophorella discreta, Cri- 


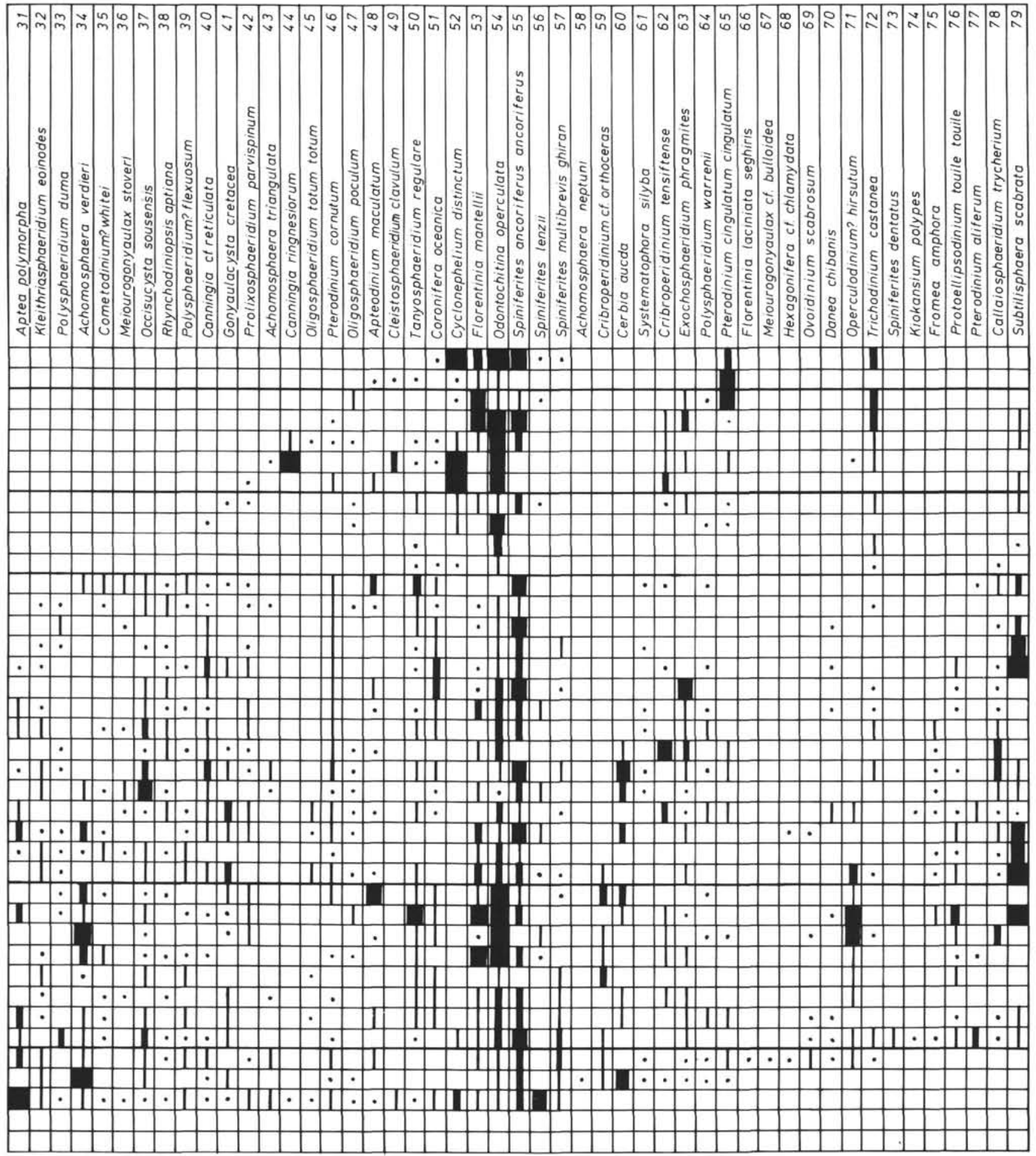

Figure 1. (Continued).

broperidinium orthoceras, Cyclonephelium maugaad, Kiokansium corollum, K. hydra, Systematophora cretacea. Litosphaeridium siphoniphorum. The distribution of other short-ranging cyst species tends gradually to increase or decrease over their stratigraphic interval: Maghrebinia perforata ssp. mirabilis, Oligosphaeridium verrucosum, Oodnadattia alata, Subtilisphaera deformans.
Most of the remaining species are short ranging to very short ranging and have variable frequency. There are only a few samples where there is no base or top range for at least one or more taxa. This allows a very detailed sequencing of Site 545 . However, such a division, based on local dinoflagellate cyst ranges, has no universal validity. Many such local guide-fossils are absent in equivalent time periods in neighboring sections, 


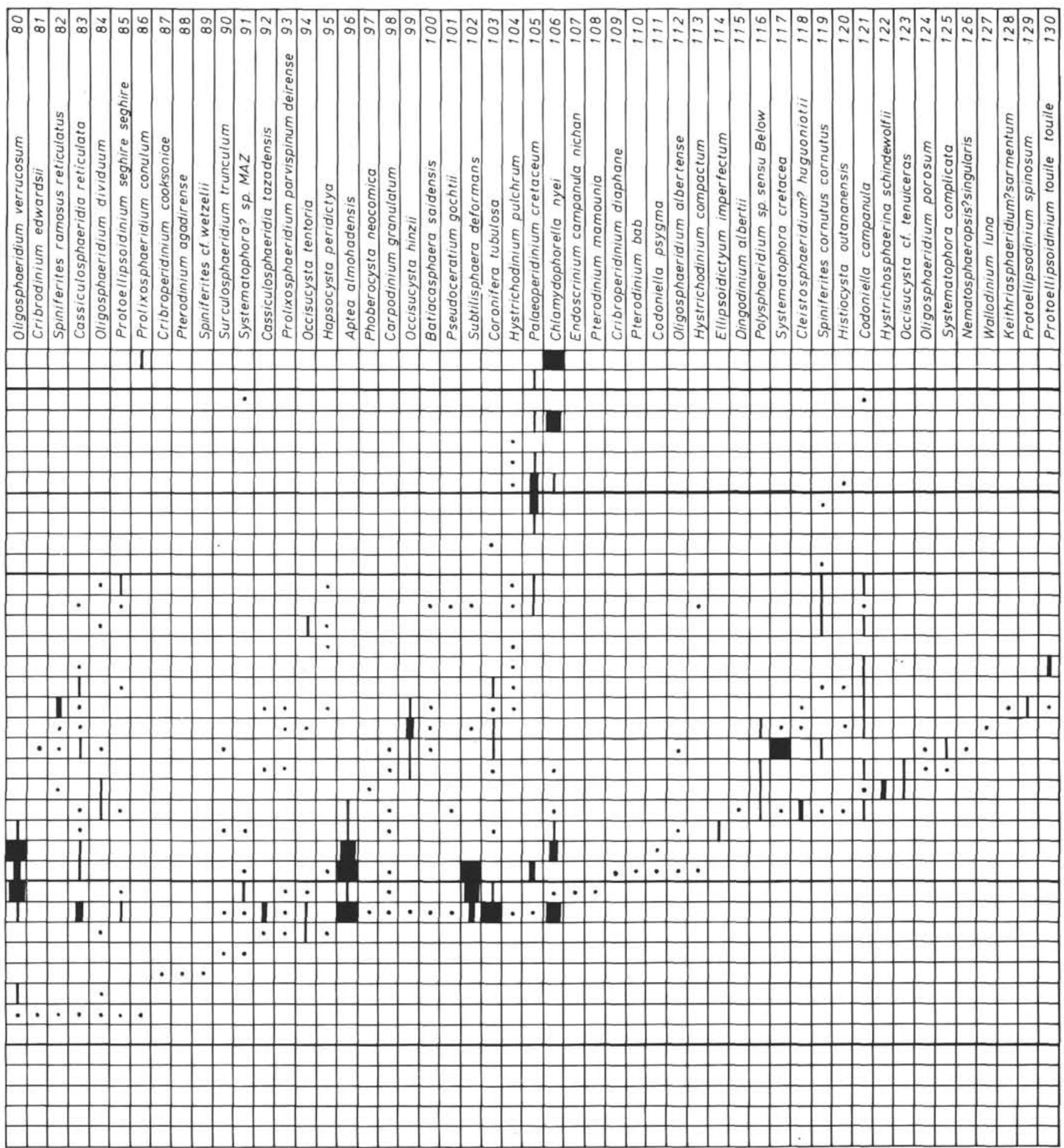

Figure 1. (Continued).

for example, Site 547 (this chapter), Site 370 (Williams, 1978), and onshore sections (Below, 1981; Below, 1982a, 1982b). Only selected samples were examined, although, in contrast to various published studies of dinoflagellate cyst assemblages, they were taken at very short intervals. Nevertheless, it is probable that many occurrences of "short-ranging" species in strata between sample points were by chance not found. Only continuous trench sampling would document all faunal horizons.
With this in mind, this chapter discusses only selected cysts, not all 160 taxa occurring at Site 545. For more detailed information about other species, the reader is referred to the dinoflagellate cyst distribution chart, Figures 1 and 2 .

The few individuals from a poor dinoflagellate cyst assemblage in Sample 545-56-6, 55-57 cm give little evidence for age determination. The four species, Oligosphaeridium complex, O. totum ssp. minor, Spiniferites 


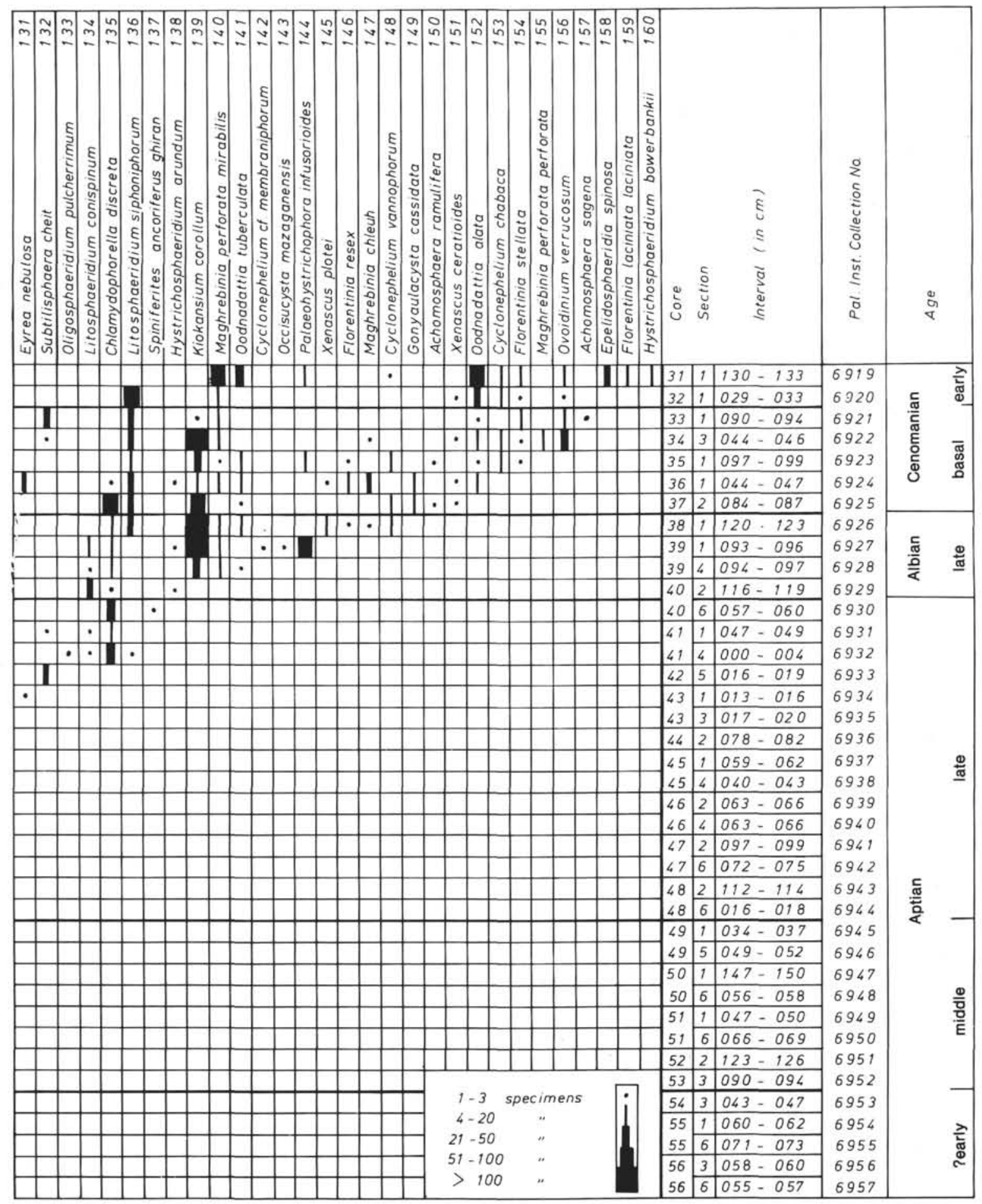

Figure 1. (Continued).

ramosus ssp. ramosus, and Tanyosphaeridium boletum, are all long-ranging taxa, known from Lower and Upper Cretaceous sediments. This sample and Sample 545-56-3, $58-60 \mathrm{~cm}$ were taken from a sequence of crushed and faulted green claystone, dated as (?Barremian) Aptian by the shipboard party (subsequently dated as early late Aptian by foraminifers; Leckie, this volume). Because of the stratigraphically insignificant dinoflagellate cyst association this age determination can neither be veri- fied nor rejected for Sample 545-56-6, 55-57 cm. However, an Aptian-even an early Aptian age-can be proposed for Sample 545-56-3, 58-60 cm, because characteristic dinoflagellate cyst populations found in middle Aptian sediments of Moroccan onshore sections do not occur below Core 53. The population of Sample 545-56$3,58-60 \mathrm{~cm}$ comprises 21 species, of which three are of stratigraphic interest: Aptea eisenackii (peak), Occisucysta tenuiceras, and Cerbia tabulata. Both of the form- 

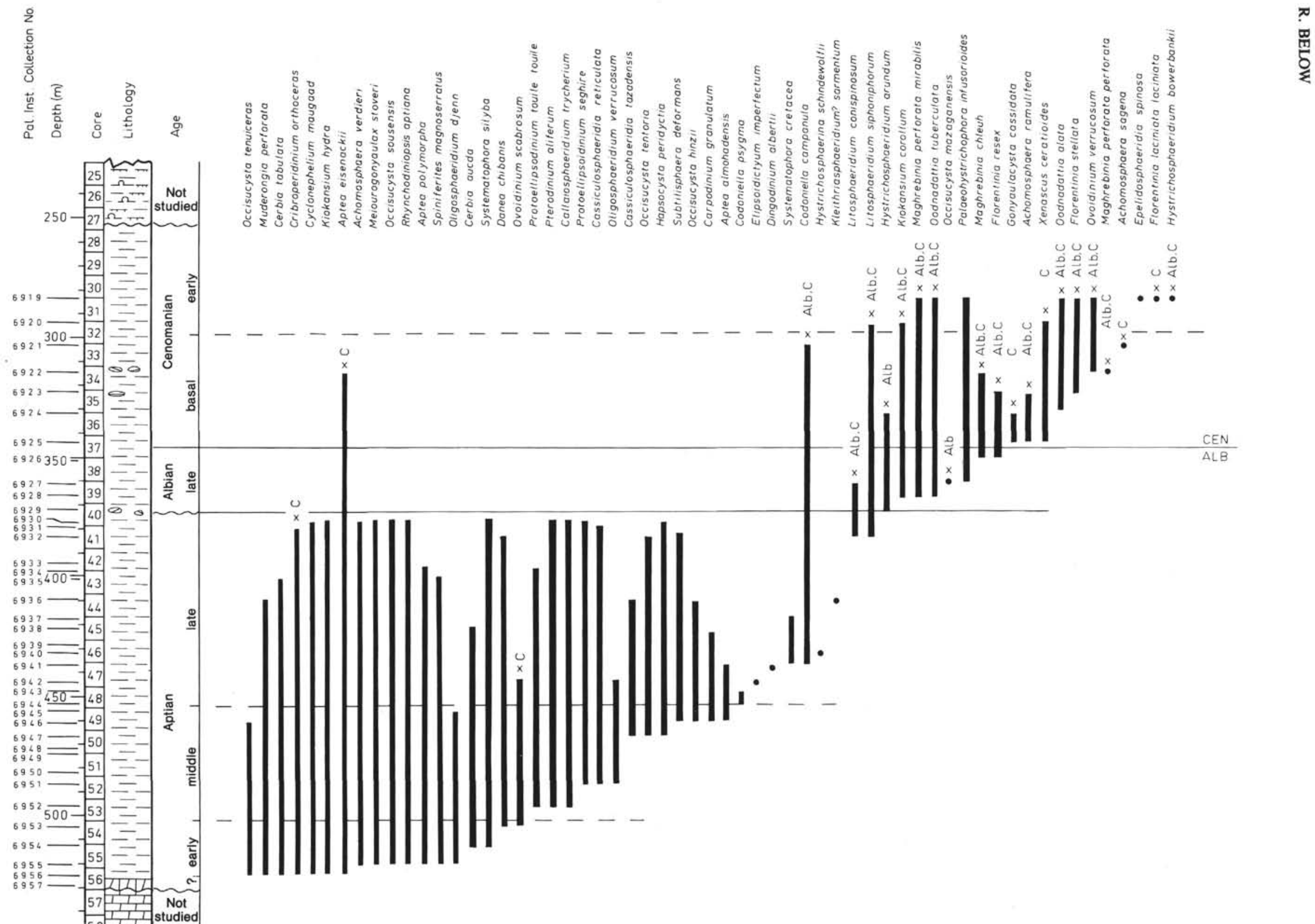

Figure 2. Stratigraphic ranges of selected dinoflagellate cysts in Hole 545, between Cores 30 and 56. X = dinoflagellate cyst taxa also present in the Albian (Alb) and/or Cenomanian (C) of Holes 547A and 547B. 
er are limited to the Aptian of the onshore Ida ou Tanane section (Below, 1981), whereas Cerbia tabulata shows equal frequency in the Barremian and Aptian of this onshore locality. Species with base ranges in this sample and maxima during the Aptian are Cribroperidinium orthoceras, Cyclonephelium maugaad, and Kiokansium hydra. The base range of Florentinia radiculata corresponds to its first occurrence in the Aptian of Site 370 (Williams, 1978).

Sample 545-55-6, 71-73 cm yielded a very rich population, both in species diversity and number of individuals. Of $\mathbf{4 8}$ dinoflagellate species, 38 have their site-specific base ranges in this sample. Sample 545-55-6, 71-73 $\mathrm{cm}$ contains dinoflagellate cysts that are regarded as typical of Aptian and/or younger sediments, such as Achomosphaera verdieri, Aptea eisenackii, A. polymorpha, $C$. maugaad, F. radiculata, O. sousensis, O. tenuiceras, and Prolixosphaeridium parvispinum. Most of these species are very abundant in this sample and thus clearly correspond to their known peak in the Aptian. Williams (1978) has demonstrated that the characteristic $P$. parvispinum (as $P$. granulosum) has its base range within Aptian sediments at Site 370. Cribroperidinium orthoceras, $K$. hydra, and Rhynchodiniopsis aptiana, which also occur in Sample 545-55-6, 71-73 cm, are typical of both Barremian and Aptian ages.

Danea chibanis, in Sample 545-54-3, 43-47 cm, is well known in the middle Aptian of Moroccan onshore sections (Below, 1981). Protoellipsodinium touile ssp. touile in Sample 545-53-3, 90-94 cm and P. seghire ssp. seghire in Sample 545-52-2, 123-126 cm strengthen the impression that these are all middle Aptian dinoflagellate cyst populations. This last sample also yields the first appearance of the morphologically very characteristic and short-ranging Oligosphaeridium verrucosum.

Only a few species are introduced as new components in the dinoflagellate cyst associations in the interval between Samples 545-51-6, 66-69 cm and 545-50-1, 147$150 \mathrm{~cm}$. Of these, Hapsocysta peridyctia and Systematophora sp. MAZ may in the future prove to be of stratigraphic value for middle Aptian time. In this sample interval, low species diversity is correlated with the absence of dominant species with high numbers of specimens.

This is obviously different in Sample 545-49-5, 49-52 $\mathrm{cm}$, which shows high species diversity and great numbers of dinoflagellate cyst individuals. Eleven species occur in this sample for the first time. Of these, Aptea almohadensis, Chlamydophorella nyei, Coronifera tubulosa, and Subtilisphaera deformans immediately become dominant species, but only for a short period. It is in this sample that Cassiculosphaeridia tazadensis has its greatest frequency; this is a significant dinoflagellate cyst from the middle Aptian in the Ida ou Tanane onshore section (Below, 1981). Morphologically characteristic species with base ranges are Carpodinium granulatum and Occisucysta hinzii.

Many species are new in the dinoflagellate cyst assemblages between Samples 545-48-6, 16-18 cm and 54544-2, 78-82 cm. Some of these are unknown in the Moroccan lower and middle Aptian: Codoniella campanu- la, C. psygma, Kleithriasphaeridium? sarmentum, $\mathrm{Ne}$ matosphaeropsis? singularis, and $O$. cf. tenuiceras. Since they are associated with dinoflagellate cyst populations in which typical Aptian species dominate, it is possible that they may indicate a late Aptian age for this stratigraphic interval. This is supported by the many Hystrichosphaerina schindewolfii specimens in Sample 545-46$4,63-66 \mathrm{~cm}$. Their presence makes it possible to connect this sample with the Systematophora schindewolfii Zone of the late Aptian (Williams, 1975, 1978). Other species, such as Ellipsoidictyum imperfectum, Oligosphaeridium indicum, and $S$. cretacea, which have base ranges in the sequence between Samples 545-47-6, 72-75 cm and 545-46-2, 63-66 cm, do not occur in the Moroccan material before the Albian. Some species typical for the Barremian-Aptian have their top ranges within the interval between Samples 545-46-2, 63-66 cm and 545-414, 0-4 cm: Cassiculosphaeridia tazadensis, Cerbia aucda, C. tabulata, Occisucysta tentoria, and Spiniferites magnoserratus. Species of the genus Cerbia seem to be good guide fossils, for they never extend above the Aptian/Albian boundary (Williams, pers. comm., 1981). Nevertheless, stratigraphically reliable species indicate that the Aptian extends as high as Sample 545-40-6, 57-60 $\mathrm{cm}$. Species having their top range within this sample and the somewhat older Sample 545-41-1, 47-49 cm are Cassiculosphaeridia reticulata, Cribroperidinium orthoceras, Cyclonephelium maugaad, K. eoinodes, Meiourogonyaulax stoveri, $O$. sousensis, Protoellipsodinium seghire ssp. seghire, Pterodinium aliferum, and Rhynchodiniopsis aptiana.

Several thin beds of claystone conglomerates have been recorded within Core 40 . Shipboard scientists proposed a very minor hiatus. Changes in the composition of dinoflagellate cyst populations demonstrate it to be a major hiatus. Sample 545-40-6, 57-60 cm, $80 \mathrm{~cm}$ below the first pebble conglomerate, is of Aptian age, whereas Sample 545-40-2, 116-119 cm yields dinoflagellate cysts typical for the very late Albian. Most species which have base ranges from Sample 545-40-2, 116-119 cm to Sample 545-31-1, 130-133 cm characterize the Albian/Cenomanian boundary. No dinoflagellates significant for the lower or middle Albian from onshore sections were recognized. Cyclonephelium chabaca, Litosphaeridium siphoniphorum, Maghrebinia chleuh, M. perforata ssp. mirabilis, $M$. perforata ssp. perforata, and Palaeohystrichophora infusorioides occur within the Ida ou Tanane onshore section in the highest Vraconian and are known to range into the Cenomanian (Below, 1981).

There are problems in determining the exact position of the Albian/Cenomanian boundary at Site 545 (see also discussion of Site 547, later). Sample 545-39-1, 93-96 $\mathrm{cm}$ contains the species $P$. infusorioides, the base range of which, according to Williams (1978), marks the beginning of the Cenomanian at Site 370. This is in agreement with the work of Clarke and Verdier (1967), who erected the Hystrichosphaeridium siphoniphorum Zone of Cenomanian to ?Turonian age with three subzones. The base of this zone and its basal subzone, respectively, are marked by the first appearance of $P$. infusorioides. Palynologically, this can be taken as the base of the Ce- 
nomanian (Clarke and Verdier, 1967). Nevertheless, Florentinia berran, F. resex, Maghrebinia chleuh, M. perforata ssp. perforata, and Oodnadattia alata, well known in upper Albian onshore sections (Below, 1981; Below, $1982 \mathrm{~b}$ ), occur within Site 545 with base ranges that are younger than the first appearance of $P$. infusorioides. A comparison of dinoflagellate cyst assemblages from welldated onshore sections with those from Site 545 seems to indicate that Xenascus ceratioides is, at least regionally, a more reliable marker for the beginning of the Cenomanian; therefore, it is used here to establish the Albian/Cenomanian boundary between Samples 545-38-1, $120-123 \mathrm{~cm}$ and $545-37-2,84-87 \mathrm{~cm}$.

According to Williams (1978), the abundant Epelidosphaeridia spinosa in Sample 545-30-1, 130-133 cm demonstrate that this stratum is not younger than earliest Cenomanian. The sequence between the first occurrence of E. spinosa and Sample 545-37-2, 84-87 cm, which contains the base range of $X$. ceratioides, would, therefore, be of basal Cenomanian age (Williams's term). This conclusion would be supported by the presence of Kiokansium corollum, whose range, according to Williams (1978, as Cleistosphaeridium polypes ssp. A), should not extend over the basal/early Cenomanian boundary.

\section{Site 547 (Holes 547A and 547B) $\left(33^{\circ} 46.84^{\prime} \mathrm{N}\right.$;} $09^{\circ} 20.98$ ' W; water depth $3938 \mathrm{~m}$ )

A total of $351 \mathrm{~m}$ of mid-Cretaceous sediment were cored in Hole 547A between Cores 39 and 73 and in the reentry Hole 547B between Cores 1 and 7 .
The sequence between Cores 547B-6 and 547A-39 consists of grayish green claystone and mudstone with common, intraformational flat-pebble mudstone conglomerate layers. It was dated by shipboard paleontologists as ranging from the late Albian to middle Cenomanian. It rests with a hiatus on Upper Jurassic to Lower Cretaceous nodular limestone and terminal claystone. The top of the mid-Cretaceous section is marked by an unconformity upon which Upper Cretaceous and Lower Tertiary strata were recorded.

Within the sequence studied here, age determinations proposed in the shipboard report using nannofossils were: $547 \mathrm{~A}-39-1,140 \mathrm{~cm}$ to $547 \mathrm{~A}-40, \mathrm{CC}$, middle and late $\mathrm{Al}-$ bian to middle Turonian; $545 \mathrm{~A}-41, \mathrm{CC}$ to $545 \mathrm{~A}-62, \mathrm{CC}$, early Cenomanian to early Turonian; $547 \mathrm{~A}-63, \mathrm{CC}$ through 547B-6-1, $107 \mathrm{~cm}$, late Albian. Ages using foraminifers were: Cores $547 \mathrm{~A}-39$ to $547 \mathrm{~A}-46$, late Cenomanian; $547 \mathrm{~A}-47$ to $547 \mathrm{~A}-62$, early Cenomanian; $547 \mathrm{~A}-63$ through 547B6-1, $107 \mathrm{~cm}$, late Albian. Redeposition within the section masks clearly defined boundaries.

\section{Analysis, Hole 547B}

Thirteen core samples were collected from a 48-m upper Albian interval in Hole 547B (with high sample density, e.g., 10 samples from $9.5 \mathrm{~m}$ of Core 5). Ninety taxa were recorded in Hole 547B; their distribution is shown in Figures 3 and 5.

All 10 samples of Core 547B-5 yielded rich dinoflagellate cyst populations. Dominant species are Cyclonephelium brevispinatum, Litosphaeridium conispinum, Odontochitina operculata, Oligosphaeridium complex,

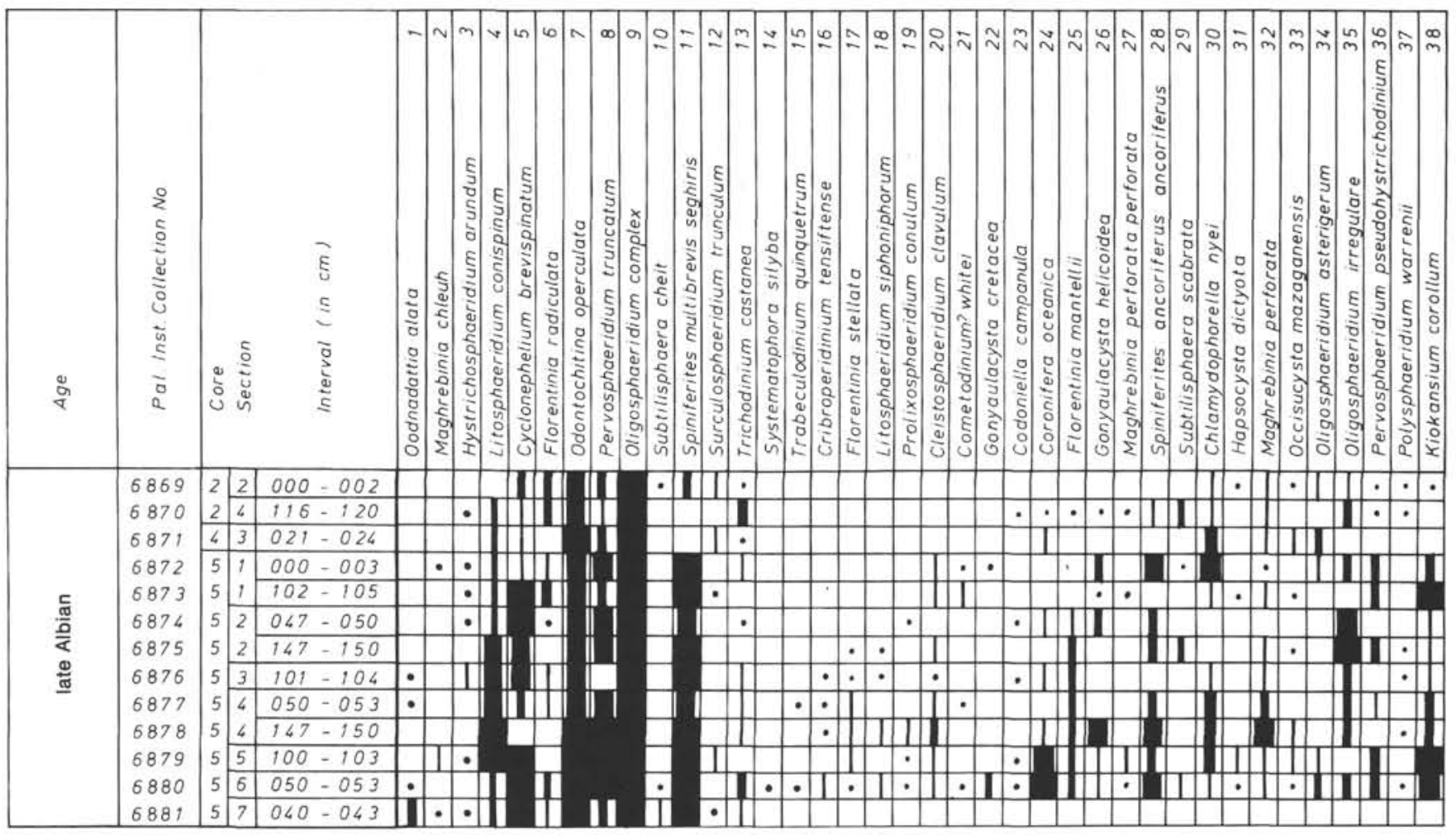

Figure 3. Distribution of dinoflagellate cysts in the late Albian of Hole 547B. 
Pervosphaeridium truncatum, and Spiniferites multibrevis ssp. seghiris. Important components are Chlamydophorella nyei, Coronifera oceanica, Exochosphaeridium phragmites, Florentinia mantellii, Gonyaulacysta helicoidea, Kiokansium corollum, Maghrebinia perforata ssp. mirabilis, $O$. irregulare, $P$. pseudohystrichodinium, $S$. ancoriferus ssp. ancoriferus, and $S$. cf. wetzelii. In comparison with dinoflagellate cysts from biostratigraphically well dated onshore sections, the association $L$. siphoniphorum, M. chleuh, M. perforata ssp. mirabilis, and $M$. perforata ssp. perforata characterize earliest Cenomanian and/or late Albian. This is supported by the presence of $F$. berran and $F$. resex in the somewhat younger Core 547B-2. However, the late Albian age is more probable and is proposed here, because Xenascus ceratioides, with a base range at the beginning of the Cenomanian (see later discussion) is absent in Hole 547B. It appears for the first time in Core 547A-69.

It is difficult to correlate Core 547B-5 with the sequence of Hole 547A. Theoretically, such correlation should be easy by comparing the distinctive base ranges of the species named earlier in Hole 545 with their base ranges in the continuous strata of Hole $547 \mathrm{~A}$, which are clear. However, these species all make their first appearance within the deepest sample in Hole 547B, Sample 547B-5-7, 40-43 cm. This first record does not of course imply that the sample is their biostratigraphic base range.

Some characteristic Aptian taxa are recorded in Hole 547B samples: Callaiosphaeridium trycherium, Cassiculosphaeridia reticulata, Muderongia perforata, Occisucysta sousensis, and Systematophora silyba. These are almost all single specimens, a fact that indicates reworking of older sediments.

\section{Analysis, Hole 547A}

Eleven core samples were collected from an $85-\mathrm{m}$ upper Albian interval in Hole 547A, and 25 samples from a 236-m Cenomanian section. An additional sample, 547A-21-4, 110-113 cm, from a conglomerate layer within Eocene sediment, was analyzed for palynomorphs. In Hole 547A 91 taxa were recorded; their distribution is shown in Figures 4 and 5.

Cores 547A-72 and 547A-73 overlap with Cores 547B-1 to $547 \mathrm{~B}-3$, and the dominant species in the dinoflagellate cyst assemblages of both core intervals correspond. The dinoflagellate cyst populations of nearly all samples collected from Hole 547A are characteristic of the Albian/Cenomanian boundary section (see earlier discussion). If one assumes that the base range of Xenascus ceratioides begins with the Cenomanian, then the interval from Samples $547 \mathrm{~A}-73-1,148-150 \mathrm{~cm}$ to $547 \mathrm{~A}$ $70-2,70-93 \mathrm{~cm}$, where $X$. ceratioides is absent, can be dated as Albian, whereas the first record of this species in Sample 547A-69-2, 108-110 cm implies that the sample is Cenomanian.

The section from Sample 547A-69-2, 108-110 cm to Sample 547A-44-2, 0-2 cm belongs to the Cenomanian Cleistosphaeridium polypes Assemblage Zone of Williams (1975), erected on the basis of dinoflagellate cyst material from Scotian shelf sections. Besides other species listed by Williams, Kiokansium corollum $(=C$. polypes sp. A sensu Williams, 1978) does not range into

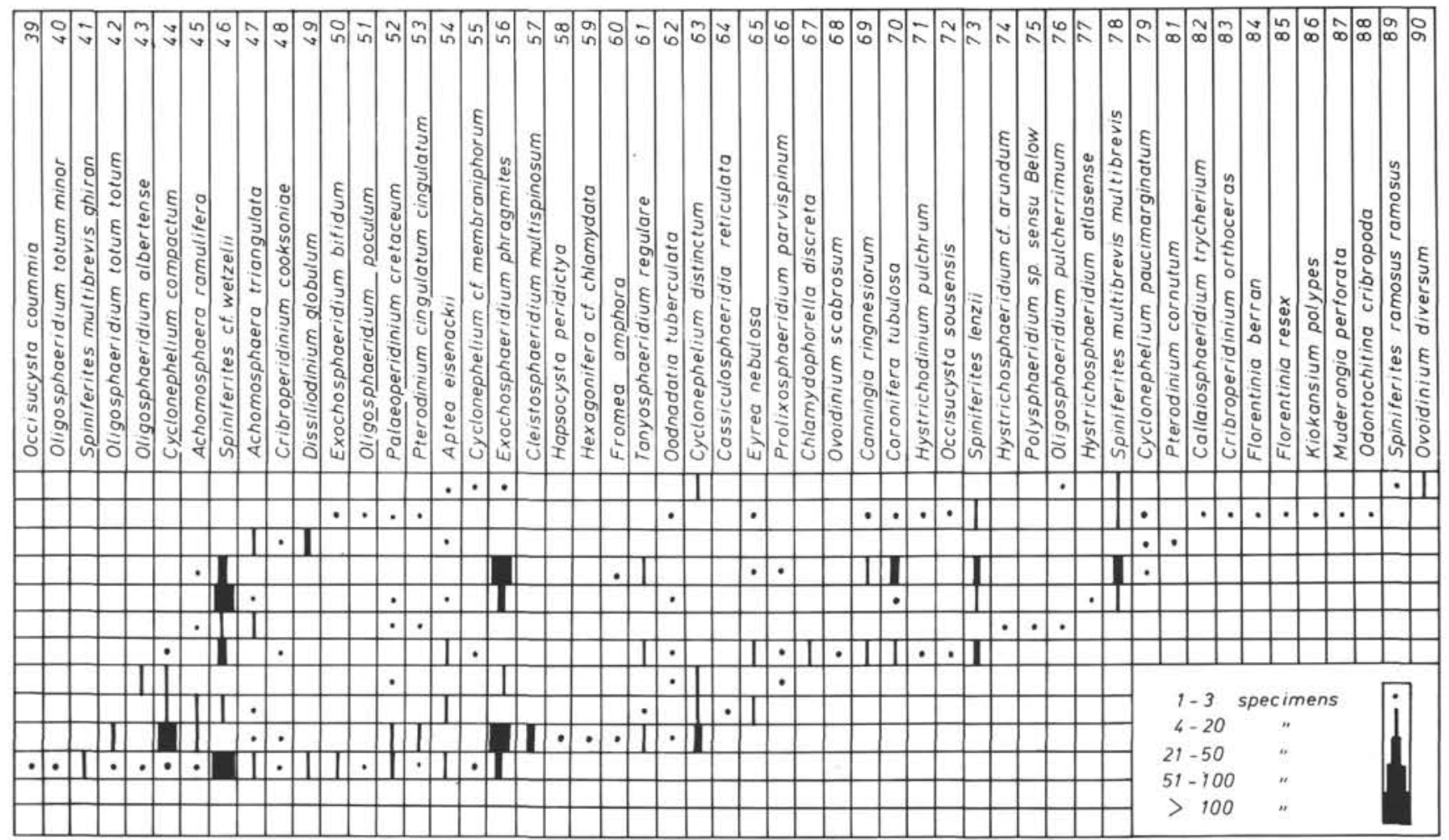

Figure 3. (Continued). 


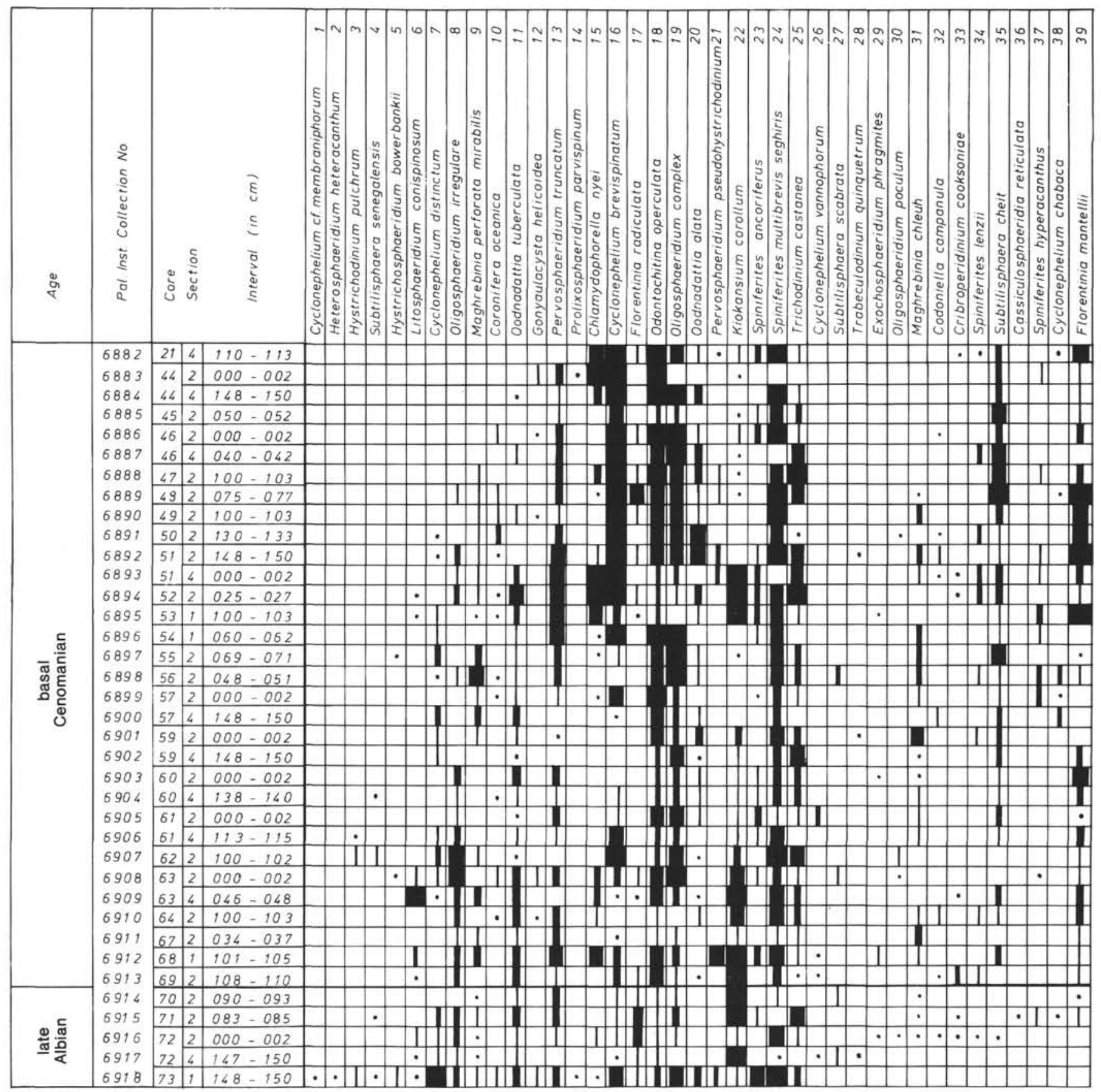

Figure 4. Distribution of dinoflagellate cysts in the Albian/Cenomanian of Hole 547A.

the Turonian. Therefore samples up to $547 \mathrm{~A}-44-2,0-2$ $\mathrm{cm}$ all with $K$. corollum, are certainly no younger than Cenomanian. According to Williams's study of dinoflaglellate cysts from Site 370 (Williams, 1978), K. corollum does not even extend into the early Cenomanian and is restricted to the base of the Cenomanian. However, detailed comparison between the data of Williams and those elaborated for Site 547 must be made very critically. Some of Williams key taxa with time-diagnostic base and top ranges, not occurring together within one population at Site 370 , are associated in a single sample from Hole 547A (examples are Florentinia radiculata and $F$. stellata, or $K$. corollum and $X$. cerati- oides). If we accept that the latest occurrence of $K$. corollum is at the base of the Cenomanian, the whole sequence from Sample 547A-69-2, 108-110 cm to Sample 547A-44-2, 0-2 cm must be dated as earliest Cenomanian. This proposal is perhaps strengthened by the absence of Epelidosphaeridia spinosa, which begins, according to Williams (1978), in the early Cenomanian, and which was used earlier in this chapter to establish the basal/early Cenomanian boundary in Hole 545 . There are similar difficulties in making comparisons with the zonation of Clarke and Verdier (1967). Their data show, for example, that Dinopterygium perforata (= Maghrebinia perforata ssp. perforata), with a top 


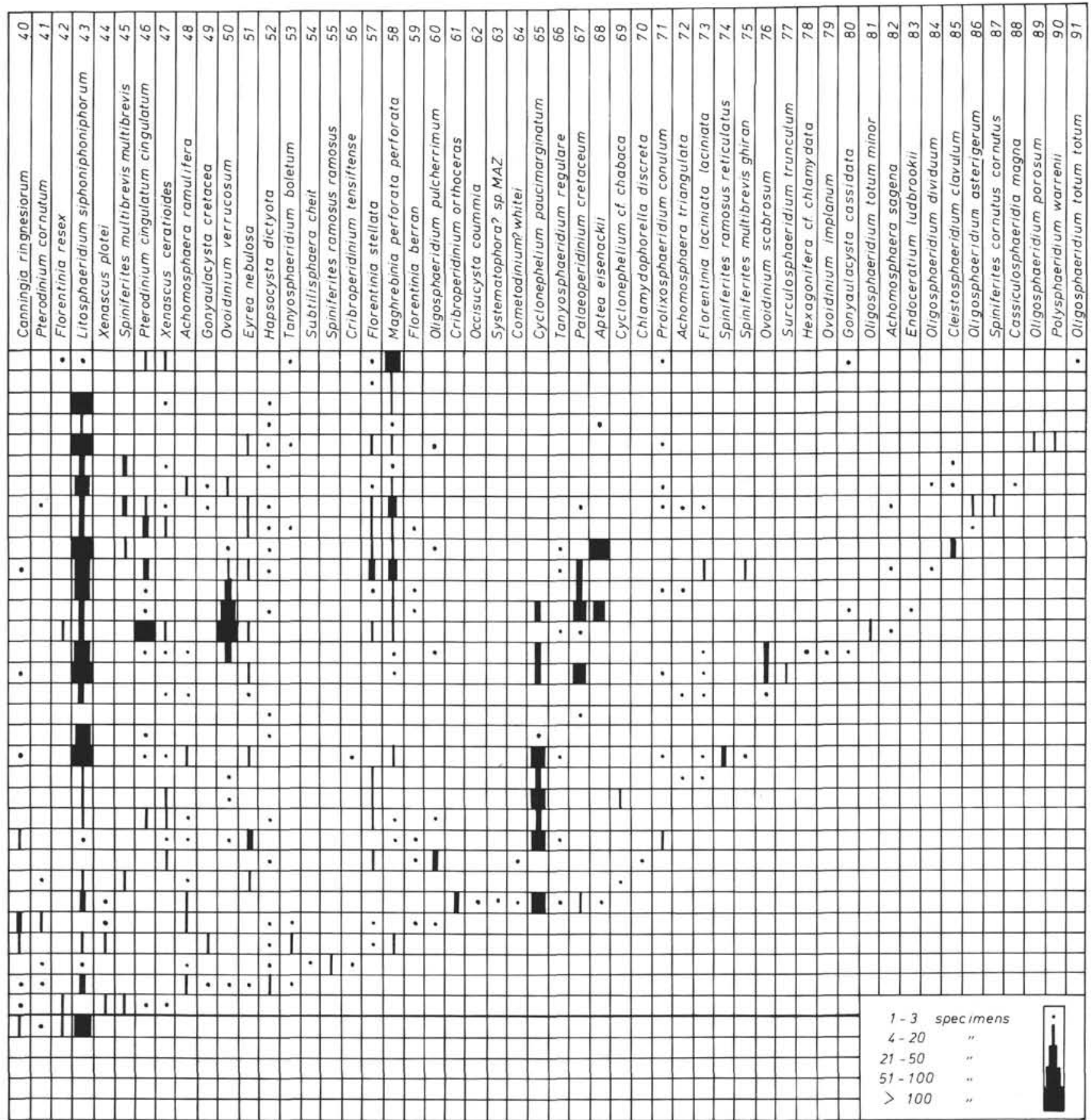

Figure 4. (Continued).

range at the upper limit of the $D$. perforata Subzone, and $X$. ceratioides, the base range of which marks the beginning of the superjacent Palaeoperidinium spinosum Subzone, are never found together. However, these fossils are found in association in many populations over a long interval in Hole 547A. It is, therefore, only possible to correlate this section, from 547A-69-2, 108$110 \mathrm{~cm}$ to $547 \mathrm{~A}-44-2,0-2 \mathrm{~cm}$ with the Hystrichosphaeridium siphoniphorum Zone of Clarke and Verdier (1967), which comprises these two subzones. Nevertheless, a more detailed local correlation of Holes 547A and 547B is possible with some characteristic short-ranging dinoflagellate cyst species, as is demonstrated in the range chart of selected dinoflagellate cyst taxa (Fig. 5).

The unit from 225 to $269 \mathrm{~m}$ of Hole 547A consists of conglomerate beds containing clasts reworked from older formations and resedimented during the Eocene. One of these clasts, Sample 547A-21-4, 110-113 cm, was analyzed for palynomorphs. The assemblage of $F$. resex, $F$. stellata, K. corollum, Litosphaeridium siphoniphorum, Maghrebinia perforata ssp. perforata, Oodnadattia ala$t a$, and $X$. ceratioides is comparable to the dinoflagel- 
R. BELOW
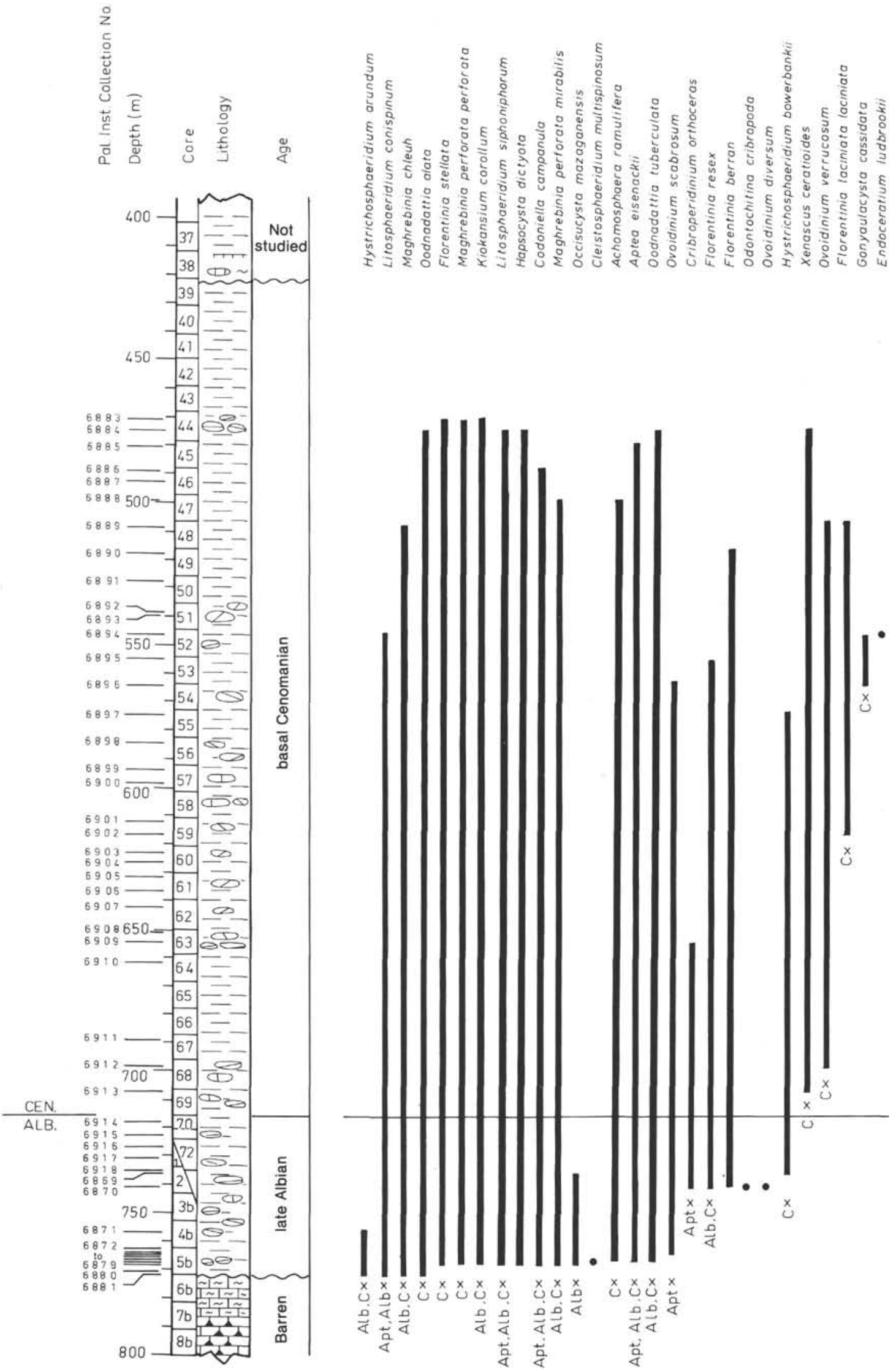

Figure 5. Stratigraphic ranges of selected dinoflagellate cysts in Hole 547A, between Cores 37 and 73 and Hole 547B, between Cores 1 and 5. X = dinoflagellate cyst taxa also present in the Aptian (Apt), Albian (Alb), and Cenomanian (C) of Hole 545 . 
late cyst populations found in the interval from Sample $547 \mathrm{~A}-69-2,108-110 \mathrm{~cm}$ to $547 \mathrm{~A}-44-2,0-2 \mathrm{~cm}$, and the clast is therefore dated as earliest Cenomanian.

\section{CONCLUSIONS}

To summarize the results of this biostratigraphic chapter, age determinations based on dinoflagellate cyst analysis are, for Holes 547,547A, and 547B:

$545-32-1,29-33 \mathrm{~cm}$ to $545-31-1,130-133 \mathrm{~cm}$ : early Cenomanian 545-37-2, 84-87 cm to 545-33-1, 90-94 cm: earliest Cenomanian $545-40-2,116-119 \mathrm{~cm}$ to $545-38-1,120-123 \mathrm{~cm}$ : late Albian $545-48-6,16-18 \mathrm{~cm}$ to $545-40-6,57-60 \mathrm{~cm}$ : late Aptian 545-53-3, 90-94 cm to 545-49-1, 34-37 cm: middle Aptian 545-56-6, 55-57 cm to 545-54-3, 43-47 cm: early (?) Aptian

547A-69-2, 108-110 cm to 547A-44-2, 0-2 cm: earliest Cenomanian

$547 \mathrm{~A}-73-1,148-150 \mathrm{~cm}$ to $547 \mathrm{~A}-70-2,90-93 \mathrm{~cm}$ : late Albian

547B-5-7, 40-43 cm to 547B-2-2, 0-2 cm: late Albian

Sites 545 and 547 are correlated by comparing the Albian/Cenomanian boundary, marked by the base range of $X$. ceratioides at the beginning of the Cenomanian. Core 545-37 is comparable to Core 547A-69, since both cores include this boundary.

\section{ADDENDUM}

At the postcruise meeting for Leg 79 it was decided that 18 additional samples of Hole 547B should be analyzed for dinoflagellate cysts. These samples are:

547B-6-2, 6-7 cm; 547B-6-3, 57-58 cm; 547B-6-4, 76-77 cm; 547B$7-4,54-56 \mathrm{~cm} ; 547 \mathrm{~B}-7-3,124-126 \mathrm{~cm}$; 547B-7-3, 94-96 cm; 547B-7-2, $133-135 \mathrm{~cm}$; 547B-7-1, 42-43 cm; 547B-8-3, 26-27 cm; 547B-8-2, $118-$ $120 \mathrm{~cm}$; 547B-8-1, 89-91 cm; 547B-10-4, 50-51 cm; 547B-10-3, 9-10 cm; 547B-10-2, 125-126 cm; 547B-11-4, 80-81 cm; 547B-11-3, 3-4 cm; $547 \mathrm{~B}-11-2,138-139 \mathrm{~cm} ; 547 \mathrm{~B}-11-1,139-140 \mathrm{~cm}$. The samples were taken from limestones with clay interbeds located immediately below the section studied in this chapter and dated by shipboard paleontologists as Early Cretaceous to Middle Jurassic. All these samples were palynologically barren.

\section{TAXONOMY}

This section is divided into two parts. The first lists names of al dinoflagellate cyst taxa encountered during this study, arranged in alphabetical order of genus names, with references to plate and figure numbers where applicable; numbers in parentheses refer to the position of the species in the distribution charts for Holes 545, 547B, and 547A (Fig. 1, 3, and 4, respectively). A zero indicates that the species is absent from that particular hole. Species marked with an asterisk are discussed in more detail in the second part, which provides morphologic descriptions or systematic classifications.

Illustrated specimens are housed in the micropaleontological collection of the Institut für Paläontologie, Rheinische Friedrich-Wilhelms Universität Bonn, Germany.

\section{Dinoflagellate Cyst Taxa}

Achomosphaera neptuni (Eisenack, 1958) Davey and Williams, 1966. (58-0-0)

Achomosphaera ramulifera (Deflandre, 1937) Evitt, 1963; Plate 1, Fig. 1. (150-45-48)

Achomosphaera sagena Davey and Williams, 1966; Plate 1, Fig 2. (157-0-82)

Achomosphaera triangulata (Gerlach, 1961) Davey and Williams, 1969; Plate 1, Fig. 3. (43-47-72)

Achomosphaera verdieri Below (1982); Plate 1, Fig. 4. (34-0-0)

Aptea almohadensis n. sp.; Plate 1, Figs. 5, 6, 7. (96-0-0)

Aptea eisenackii (Davey, 1969) Davey and Verdier, 1974; Plate 1, Fig 8, 9. (17-54-68)

Aptea polymorpha Eisenack, 1958; Plate 1, Fig. 10, (31-0-0)
Apteodinium maculatum Eisenack and Cookson, 1960; Plate 1, Fig. 11. (48-0-0)

Batiacasphaera saidensis Below, 1981; Plate 1, Fig. 12. (100-0-0)

Callaiosphaeridium trycherium Duxbury, 1980. (78-82-0)

Canningia reticulata Cookson and Eisenack, 1960. (40-0-0)

Canningia ringnesiorum Manum and Cookson, 1964. (44-69-40)

Carpodinium granulatum Cookson and Eisenack, 1962; Plate 1, Figs. 13, 14. $(98-0-0)$

Cassiculosphaeridia magna Davey, 1974. (0-0-88)

Cassiculosphaeridia reticulata Davey, 1969; Plate 2, Fig. 2. (83-64-36)

Cassiculosphaeridia tazad ensis Below, 1981. (92-0-0)

Cerbia aucda Below, 1981. (60-0-0)

Cerbia tabulata (Davey and Verdier, 1974) Below, 1981; Plate 2, Fig. 2. (9-0-0)

Chlamydophorella discreta Clarke and Verdier, 1967. (135-67-70)

Chlamydophorella nyei Cookson and Eisenack, 1958. (106-30-15)

Cleistosphaeridium clavulum (Davey, 1969) Below (1982); Plate 2, Fig. 3. (49-20-85)

Cleistosphaeridium? huguoniotii (Valensi, 1955) Davey, 1978. (118-00)

Cleistosphaeridium multispinosum (Singh, 1964) Brideaux, 1971; Plate 2, Fig. 4. (0-57-0)

Codoniella campanula (Cookson and Eisenack, 1960) Downie and Sarjeant, 1965, emend. Davey, 1979; Plate 2, Fig. 5. (121-23-32)

Codoniella psygma Davey, 1979; Plate 2, Figs. 6, 7. (111-0-0)

Cometodinium? whitei (Deflandre and Courteville, 1939) Stover and Evitt, 1978; Plate 2, Fig. 8. (35-21-64)

Coronifera oceanica Cookson and Eisenack, 1958; Plate 2, Fig. 9. (51-24-10)

Coronifera tubulosa Cookson and Eisenack, 1974; Plate 2, Fig. 10. (103-70-0)

Cribroperidinium cooksoniae Norvick, 1976. (87-48-33)

Cribroperidinium diaphane (Cookson and Eisenack, 1958) Stover and Evitt, 1978. (109-0-0)

Cribroperidinium cf. diaphane (Cookson and Eisenack, 1958) Stover and Evitt, 1978. (5-0-0)

Cribroperidinium edwardsii (Cookson and Eisenack, 1958) Davey, 1969. (81-0-0)

Cribroperidinium orthoceras Eisenack, 1958; Plate 2, Fig. 11. (12-8361)

Cribroperidinium cf. orthoceras Eisenack, 1958 sensu Below, 1981. (59-0-0)

Cribroperidinium tensiftense Below, 1981. (62-16-56)

Cyclonephelium brevispinatum (Millioud, 1969) Yun, 1981; Plate 2, Fig. 12. (21-5-16)

Cyclonephelium chabaca Below, 1981; Plate 2, Fig. 13. (153-0-38)

Cyclonephelium cf. chabaca Below, 1981. (0-0-69)

Cyclonephelium compactum Deflandre and Cookson, 1955; Plate 2, Fig. 14; Plate 3, Fig. 1. (0-44-0)

Cyclonephelium distinctum Deflandre and Cookson, 1955; Plate 3, Figs. 2, 3. (52-63-7)

Cyclonephelium hystrix (Eisenack, 1958) Davey, 1978; Plate 3, Fig. 4. (19-0-0)

Cyclonephelium maugaad Below, 1981; Plate 3, Fig. 5. (13-0-0)

Cyclonephelium cf. membraniphorum Cookson and Eisenack, 1962; Plate 3, Fig. 6. (142-55-1)

Cyclonephelium paucimarginatum Cookson and Eisenack, 1962; Plate 3, Fig. 7. (25-79-65)

Cyclonephelium vannophorum Davey, 1969. (148-0-26)

Cyclonephelium cf. vannophorum Davey, 1969. (26-0-0)

Danea chibanis Below, 1981. (70-0-0)

Dingodinium albertii Sarjeant, 1966; Plate 3, Fig. 8. (115-0-0)

Dissiliodinium globulum Drugg, 1978; Plate 3, Figs. 9, 10, 11. (1149-0)*

Ellipsoidictyum imperfectum (Brideaux and McIntyre, 1975) Lentin and Williams, 1977; Plate 3, Fig. 12. (114-0-0)

Endoceratium ludbrookii (Cookson and Eisenack, 1958) Loeblich and Loeblich, 1966. (0-0-83)

Endoscrinium campanula (Gocht, 1959) Vozzhennikova, 1967 ssp. nichan Below, 1981. (107-0-0)

Epelidosphaeridia spinosa (Cookson and Hughes, 1964) Davey, 1969; Plate 3, Fig. 13. (158-0-0)

Exochosphaeridium bifidum (Clarke and Verdier, 1967) Clarke, Davey, Sarjeant, and Verdier, 1968; Plate 3, Fig. 14. (15-50-0)

Exochosphaeridium phragmites Davey, Downie, Sarjeant, and William, 1966. (63-56-29) 
Eyrea nebulosa Cookson and Eisenack, 1958; Plate 3, Fig. 15. (13165-51)

Florentinia berran Below (1982). (0-84-59)

Florentinia laciniata ssp. laciniata Davey and Verdier, 1973; Plate 4, Fig. 1. (159-0-73)

Florentinia laciniata Davey and Verdier, 1973 ssp. seghiris Below (in press). (66-0-0)

Florentinia mantellii (Davey and Williams, 1966) Davey and Verdier, 1973; Plate 4, Fig. 2. (53-25-39)

Florentinia radiculata (Davey and Williams, 1966) Davey and Verdier, 1973, emend. Davey and Verdier, 1976; Plate 4, Fig. 3. (20-6-17)

Florentinia resex Davey and Verdier, 1976; Plate 4, Fig. 4. (146-85-42)

Florentinia stellata (Maier, 1959) Below (1982); Plate 4, Fig. 5. (15417-57)

Fromea amphora Cookson and Eisenack, 1958; Plate 4, Fig. 6. (7560-0)

Gonyaulacysta cassidata (Eisenack and Cookson, 1960) Sarjeant, 1966. (149-0-80)

Gonyaulacysta cretacea (Neale and Sarjeant, 1962) Sarjeant, 1969; Plate 4, Fig. 7. (41-22-49)

Gonyaulacysta helicoidea (Eisenack and Cookson, 1960) Sarjeant, 1966; Plate 4, Fig. 8. (22-26-12)

Hapsocysta dictyota Davey, 1979; Plate 4, Fig. 9. (0-31-52)

Hapsocysta peridyctia (Eisenack and Cookson, 1960) Davey 1979. (95-58-0)

Heterosphaeridium heteracanthum (Deflandre and Cookson, 1955) Eisenack and Kjellström, 1971. (16-0-2)

Hexagonifera cf. chlamydata Cookson and Eisenack, 1962; Plate 4, Fig. 10. (68-59-78)

Histiocysta outananensis Below, 1981. (120-0-0)

Hystrichodinium compactum Alberti, 1961. (113-0-0)

Hystrichodinium pulchrum Deflandre, 1935. (104-71-3)

Hystrichosphaeridium arundum Eisenack and Cookson, 1960; Plate 4, Fig. 11. (138-3-0)

Hystrichosphaeridium cf. arundum Eisenack and Cookson, 1960; Plate 4, Fig. 12. (0-74-0)*

Hystrichosphaeridium atlasense Below (1982); Plate 4, Fig. 13. (0-770)

Hystrichosphaeridium bowerbankii Davey and Williams, 1966; Plate 5, Fig. 1. (160-0-5)

Hystrichosphaerina schindewolfii Alberti, 1961. (122-0-0)

Kiokansium corollum (Hasenboehler, in press); Plate 5, Fig. 2, 3, 4. (139-38-22)

Kiokansium hydra (Duxbury, 1979) Below (1982); Plate 5, Fig. 5. (14$0-0)$

Kiokansium polypes (Cookson and Eisenack, 1964) Below (in press); Plate 5, Fig. 5. (74-86-0)

Kleithriasphaeridium eoinodes (Eisenack, 1958) Davey, 1974; Plate 5, Fig. 7. (32-0-0)

Kleithraisphaeridium? sarmentum (Davey, 1979) Below (1982); Plate 5, Fig. 8. (128-0-0)

Litosphaeridium conispinum Davey and Verdier, 1973; Plate 5, Fig. 9. (134-4-6)

Litosphaeridium siphoniphorum (Cookson and Eisenack, 1958) Davey and Williams, 1966; Plate 5, Figs. 10, 11 (136-78-43)

Maghrebinia chleuh Below, 1981; Plate 6, Fig. 1. (147-2-31)

Maghrebinia perforata (Clarke and Verdier, 1967) Below, 1981 ssp. mirabilis n.ssp.; Plate 6, Fig. 2. (140-32-9)*

Maghrebinia perforata (Clarke and Verdier, 1967) emend. Below, 1981 ssp. perforata; Plate 6, Fig. 3. (155-27-58)

Meiourogonyaulax cf. bulloidea (Cookson and Eisenack, 1960) Sarjeant, 1969; Plate 6, Fig. 4. (67-0-0)

Meiourogonyaulax stoveri Millioud, 1969. (36-0-0)

Muderongia perforata Alberti, 1961; Plate 6, Figs. 5, 6. (8-87-0)

Nematosphaeropsis? singularis Davey, 1979. (126-0-0)

Occisucysta coummia Below, 1981. (0-39-62)

Occisucysta hinzii n.sp.; Plate 6, Figs. 7, 8. (99-0-0)*

Occisucysta mazaganensis n.sp.; Plate 6, Fig. 9; Plate 7, Fig. 1. (14333-0)*

Occisucysta sousensis Below, 1981; Plate 7, Fig. 2 (37-72-0)

Occisucysta tentoria Duxbury, 1977. (94-0-0)

Occisucysta tenuiceras (Eisenack, 1958) Below, 1981. (94-0-0)

Occisucysta cf. tenuiceras (Eisenack, 1958) Below, 1981. (123-0-0)

Odontochitina cribropoda Deflandre and Cookson, 1955. (0-88-0)

Odontochitina operculata (O. Wetzel, 1933) Deflandre and Cookson, 1955; Plate 7, Fig. 3. (54-7-18)
Oligosphaeridium albertense Pocock, 1962. (112-43-0)

Oligosphaeridium asterigerum (Gocht, 1959) Davey and Williams 1969; Plate 7, Fig. 4. (28-34-86)

Oligosphaeridium complex (White, 1842) Davey and Williams, 1966; Plate 7, Fig. 5. (3-9-19)

Oligosphaeridium dividuum Williams, 1978; Plate 7, Fig. 6. (84-0-84)

Oligosphaeridium djenn Below (in press). (27-0-0)

Oligosphaeridium indicum (Jain, 1977) Below (1982); (124-0-89)

Oligosphaeridium irregulare (Pocock, 1962) Davey and Williams, 1969;

Oligosphaeridium poculum Jain, 1977; Plate 7, Fig. 8. (47-51-30)

Oligosphaeridium pulcherrimum (Deflandre and Cookson, 1955) Davey and Williams, 1966; Plate 7, Fig. 9. (133-76-60)

Oligosphaeridium totum Brideaux, 1971 ssp. totum. (45-42-91)

Oligosphaeridium totum Brideaux 1971 ssp. minor (Brideaux, 1971) Lentin and Williams, 1973; Plate 7. Fig. 10. (1-40-81)

Oligosphaeridium verrucosum Davey, 1979; Plate 7, Figs. 11, 12, 13. (80-0-0)*

Oodnadattia alata (Cookson and Eisenack, 1962) Below, 1981; Plate 8, Figs. 1, 2. (152-1-20)

Oodnadattia tuberculata Eisenack and Cookson, emend, Below, 1981; Plate 8, Figs. 3, 4. (141-62-11)

Operculodinium? hirsutum (Ehrenberg, 1838) Lentin and Williams, 1973. (71-0-0)

Ovoidinium diversum? Davey, 1979; Plate 8, Fig. 5 (0-90-0)

Ovoidinium implanum Davey, 1979; Plate 8, Fig. 6. (0-0-79)

Ovoidinium scabrosum (Cookson and Hughes, 1964) Davey, 1970; Plate 8, Fig. 7, 8. (69-68-76)

Ovoidinium verrucosum (Cookson and Hughes, 1964) Davey, 1970; Plate 8, Figs. 9, 10. (156-0-50)

Palaeohystrichophora infusorioides Deflandre, 1935; Plate 8, Fig. 11. (144-0-0)

Palaeoperidinium cretaceum Pocock, 1962; Plate 8, Fig. 12. (105-5267)

Pervosphaeridium pseudohystrichodinium (Deflandre, 1937) Yun, 1981; Plate 8, Fig. 13. (0-36-21)

Pervosphaeridium truncatum (Davey, 1969) Below (1982). Plate 8, Fig. 14. (23-8-13)

Phoberocysta neocomica Gocht, 1957. (97-0-0)

Polysphaeridium duma Below (1982). (33-0-0)

Polysphaeridium? flexuosum (Davey, Downie, Sarjeant, and Williams) Below (in press). (39-0-0)

Polysphaeridium sp. sensu Below (1982); Plate 8, Fig. 15. (116-75-0)

Polysphaeridium warrenii Habib, 1975; Plate 9, Fig. 1. (64-37-90)

Prolixosphaeridium conulum Davey, 1969; Plate 9, Fig. 2. (86-19-71)

Prolixosphaeridium parvispinum (Deflandre, 1937) Davey and Williams, 1969 ssp. deirense (Davey, Downie, Sarjeant, and Williams, 1966) Below (1982); Plate 9, Fig. 3. (93-0-0)

Prolixosphaeridium parvispinum (Deflandre, 1937) Davey and Williams, 1969 ssp. parvispinum; Plate 9, Fig. 4. (42-66-14)

Protoellipsodinium seghire Below, 1981 ssp. seghire. (85-0-0)

Protoellipsodinium spinosum Davey and Verdier, 1971. (129-0-0)

Protoellipsodinium touile Below, 1981 ssp. touile. (76-0-0)

Pseudoceratium gochtii Neale and Sarjeant, 1962. (101-0-0)

Pterodinium aliferum Eisenack, 1958. (77-0-0)

Pterodinium agadirense Below, 1981. (88-0-0)

Pterodinium bab Below, 1981. (110-0-0)

Pterodinium cingulatum (O. Wetzel, 1933) Below, 1981 ssp. cingulatum; Plate 9, Fig. 5 (65-53-46)

Pterodinium cornutum Cookson and Eisenack, 1962; Plate 9, Figs. 6, 7. $(46-81-41)$

Pterodinium mamounia Below, 1981. (108-0-0)

Rhynchodiniopsis aptiana Deflandre, 1935. (38-0-0)

Spiniferites ancoriferus Cookson and Eisenack, 1974, ssp. ancoriferus; Plate 9, Fig. 8. (55-28-23)

Spiniferites ancoriferus Cookson and Eisenack, 1974 ssp. ghiran Below (1982). (137-0-0)

Spiniferites cornutus (Gerlach, 1961) Sarjeant, 1970; Plate 9, Fig. 9. (119-0-87)

Spiniferites dentatus (Gocht, 1959) Lentin and Williams, 1973, emend. Duxbury, 1977. (73-0-0)

Spiniferites hyperacanthus (Deflandre and Cookson, 1955) Cookson and Eisenack, 1974; Plate 9, Fig. 10. (29-0-37)

Spiniferites lenzii Below (1982); Plate 9, Fig. 11. (56-73-34)

Spiniferites magnoserratus (Cookson and Eisenack, 1962) Stover and Evitt, 1978. (30-0-0) 
Spiniferites multibrevis (Davey and Williams, 1966) ssp. ghiran Below (1982); Plate 9, Fig. 12. (57-41-75)

Spiniferites multibrevis (Davey and Williams, 1966) Below (1982) ssp. multibrevis; Plate 9, Fig. 13. (6-78-45)

Spiniferites multibrevis (Davey and Williams, 1966) Below (1982) ssp. seghiris Below (1982); Plate 9, Fig. 14. (24-11-24)

Spiniferites ramosus (Ehrenberg, 1838) Loeblich and Loeblich, 1966 ssp. ramosus. (2-89-55)

Spiniferites ramosus (Ehrenberg, 1838) Loeblich and Loeblich, 1966 ssp. reticulatus (Davey and Williams, 1966) Lentin and Williams, 1973. (82-0-74)

Spiniferites cf. wetzelii (Deflandre, 1937) Sarjeant, 1970; Plate 9, Fig. 15. $(89-46-0)^{*}$

Subtilisphaera deformans (Davey and Verdier, 1973) Stover and Evitt, 1978; Plate 10, Fig. 1. (102-0-0)

Subtilisphaera cheit Below, 1982. (132-10-35)

Subtilisphaera scabrata Jain and Millepied, 1973. (79-29-27)

Subtilisphara senegalensis Jain and Millepied, 1973. (10-0-4)

Surculosphaeridium trunculum Davey, 1979. (90-12-77)

Systematophora? sp. MAZ; Plate 10, Fig. 2. (91-0-63)*

Systematophora complicata Neale and Sarjeant, 1962. (125-0-0)

Systematophora cretacea Davey, 1979; Plate 10, Figs. 3, 4. (117-0-0)

Systematophora silyba Davey, 1979. (61-14-0)

Tanyosphaeridium boletum Davey, 1974; Plate 10, Fig. 5. (4-0-53)

Tanyosphaeridium regulare Davey and Williams, 1966. (50-61-66)

Trabeculodinium quinquetrum Duxbury, 1980; Plate 10, Fig. 6. (015-28)

Trichodinium castanea (Deflandre, 1935) Clarke and Verdier, 1967; Plate 10, Fig. 7. (72-13-25)

Wallodinium luna (Cookson and Eisenack, 1960) Lentin and Williams, 1973; Plate 20, Fig. 8. (127-0-0)

Xenascus ceratioides (Deflandre, 1937) Lentin and Williams, 1973; Plate 10, Figs. 9-12. (151-0-47)

Xenascus plotei Below, 1981. (145-0-44)

\section{Description of Selected Dinoflagellate Cyst Taxa}

Class DINOPHYCEAE Fritsch, 1929

Order PERIDINIALES Haeckel, 1894

Genus APTEA Eisenack 1958, emend. Davey and Verdier, 1974

Junior synonyms. Aptea Eisenack, 1958, emend. Dörhöfer and Davies, 1980; Doidyx Sarjeant, 1966.

Type species. Aptea polymorpha Eisenack, 1958.

Diagnosis. Eisenack, 1958, p. 393; Davey and Verdier, 1974, p. 640.

\section{Aptea almohadensis n.sp.}

(Plate 1, Figs. 5, 6, 7)

Derivatio nominis. After the dynasty of the Almohavids, kings of the Maghreb in the eleventh century.

Diagnosis. Proximate, lenticular cyst, shape subsphaeroidal to asymmetrical; with a left antapical bulge and occasionally with a right lateral bulge in the region of the postcingular paraplate girdle. Apex rounded or with a narrow bulge. Paratabulation presumably ceratiacean-not completely indicated: $1^{\prime}-4^{\prime}, 1^{\prime \prime}-6^{\prime \prime \prime}$ as, Xc, $\mathrm{X}^{\prime \prime \prime}, \mathrm{Xs}$, $\mathrm{X}^{\prime \prime}$ ', Archeopyle apical, with simple, free, asymmetrical operculum, type $\overline{4 A_{1^{\prime}-4^{\prime}}}$. Autophragma of varying thickness, very finely reticulated, rarely smooth. Cyst ornamentation very sparse and in most cases without rules of orientation. Ornaments as low, solid, flattened, interconnected ledges, isolated short spines with distally acuminated or blunted ends, or simple cones forming tubercles. Sometimes these ornaments are arranged to pandasutural lines.

Holotype. Slide II-6946: 49.6/100.1

Type locality. Leg 79, Sample 545-49-5, 49-52 cm.

Dimensions. Holotype length (without apical calotte) $58 \mu \mathrm{m}$, breadth $60 \mu \mathrm{m}$, maximal height of ornaments $2 \mu \mathrm{m}$; other specimens: length 50-60 $\mu \mathrm{m}$, breadth $60-75 \mu \mathrm{m}$, maximal height of ornaments $1-4 \mu \mathrm{m}$.

Description. The cyst shape is highly variable because of the development of an apical, right lateral and an asymmetrically arranged antapical bulge. Specimens with an asymmetrical shape caused by the presence of a left antapical bulge and therefore typical of the genus Aptea are present, as well as cysts with a subsphaeroidal or sphaeroidal outline typical of the genus Cyclonephelium. The additional development of a right lateral bulge shows the close connection of these specimens to individuals of the genus Pseudoceratium. Reconstruction of paratabulation is only indirectly possible for the epicyst by studying the archeopyle suture and breakages of opercula and archeopyle margin. There are four apical paraplates. 1' and 2' are compact and polygonal, whereas $3^{\prime}$ and $4^{\prime}$ are typically elongated and thus cause the very asymmetrical operculum shape. The precingular paraplate series is divided into six precingulars and the plate as. Paratabulation of the hypocyst is unknown. The sparse distribution of low ornaments such as spines or tubercles makes any consideration of penitabular alignment along parasutures impossible. Because of this pandasutural zones are also not developed. In few cases, ornamentation is absent.

Comparison. This new species is related to Aptea eisenackii (Davey, 1969) Davey and Verdier, 1974. The sparse cyst ornamentation characteristic of $A$. almohadensis is a result of the strong reduction of ornaments in A. eisenackii.

Occurrence. See Figure 1, No. 96: Sample $545-49-5,49-52 \mathrm{~cm}$ to Sample 545-47-2, 97-99 cm; middle to late Aptian.

\section{Genus DISSILIODINIUM Drugg, 1978}

Type species. Dissiliodinium globulum Drugg, 1978.

Diagnosis. Drugg, 1978, p. 45.

\section{Dissiliodinium globulum Drugg, 1978}

(Plate 3, Figs. 9, 10, 11)

Remarks. Research results of archeopyle type and epicystal paraplate patterns compiled by Below (1981) are verified by the rich DSDP material. Nevertheless, a few remarks about the existence of special apical structures that can be interpreted as reflections of preapical plates of motile dinoflagellate theca must be added. The structure, a small, smooth apical area, is somewhat raised against the surrounding cyst wall. In other cases, boundaries are marked as faint lines that result from a fusion of the small granulae of the cyst wall. This interesting structure, interpretated as reflections of $1 \mathrm{PR}$ and $2 \mathrm{PR}$, is illustrated in Plate 3, Fig. 10.

Occurrence. See Figure 1, No. 11: Sample $545-56-3,58-60 \mathrm{~cm}$ to Sample 545-41-4, 0-4 cm, Aptian; Figure 3, No. 49: Sample 547B-5-5, $100-103 \mathrm{~cm}$ to Sample 547B-4-3, 21-24 cm; late Albian.

\section{Genus HYSTRICHOSPHAERIDIUM Deflandre, 1937, emend. Davey and Williams, 1966}

Type species. Hystrichosphaeridium tubiferum (Ehrenberg, 1838) Deflandre, 1937, emend. Davey and Williams, 1966.

Diagnosis. Deflandre, 1937, p. 68; Davey and Williams, 1966b, p. 55.

Hystrichosphaeridium cf. arundum Eisenack and Cookson, 1960 (Plate 4, Fig. 12)

Remarks. The single specimen from the sample 547B-5-2, 47-50 cm is characterized by elongate, buccinate appendages that abruptly widen distally to funnels having twice the diameter of the process. In this process morphology, the cyst differs from the tubiferous appendages of a typical Hystrichosphaeridium arundum Eisenack and Cookson. The processes of $H$. cf. arundum with a length of 0.5 cyst diameter are significantly longer than the processes of $H$. arundum, with a length of 0.25 of a cyst diameter.

Occurrence. See Figure 3, No. 74: Sample 547B-5-2, 47-50 cm; late Albian.

\section{Genus MAGHREBINIA Below, 1981}

Type species. Maghrebinia perforata (Clarke and Verdier 1967) Below, 1981.

Diagnosis. Below, 1981, p. 22.

\section{Maghrebinia perforata (Clarke and Verdier, 1967) Below 1981 ssp. mirabilis n. ssp.}

(Plate 6, Fig. 2)

Derivatio nominis. Latin mirabilis, beautiful.

Diagnosis. Chorate, somewhat lenticular cyst with bitrapezoidal size. Divided into a small epicyst and a greater hypocyst by an equatorial planispiral intratabular membrane. Paraplates bordered by high, distally denticulated, perforated or unperforated membranes, which are often irregularly and deeply slit. An apical area with few intratabular processes as well as the antapical, four precingular, and three postcingular paraplates are bordered by these septa. Nevertheless, the 
paraplate scheme could be $3^{\prime}-? 4^{\prime}, 5^{\prime \prime}$, Oc, $4^{\prime \prime \prime}, 1^{\prime \prime} \prime^{\prime \prime}$ because the large ventral area between polar plates is undifferentiated. The right end of the paracingulum extends into this area. The cyst surface is microfrangate (see Below, 1981, p. 23). Endophragmal gonal membranal thickening is often perforated. Archeopyle type $\bar{A}$.

Holotype. The specimen shown as Maghrebinia perforata (Clarke and Verdier, 1967) Below, 1981 in Plate 1, Figs. 1a, 1b, 1c, in Below 1981; slide VIII-4744 1/8.

Type locality. Section Ida ou Tanane in the north of Agadir, Morocco, section-meter 152 .

Type level. basal Cenomanian.

Dimensions. Holotype: length $80 \mu \mathrm{m}$; paratypes: length $62-96 \mu \mathrm{m}$, breadth $60-90 \mu \mathrm{m}$.

Remarks. The subspecies Maghrebinia perforata (Clarke and Verdier, 1967) Below, 1981 ssp. mirabilis n.ssp. differs from $M$. perforata (Clarke and Verdier, 1967) Below, 1981 ssp. perforata by its coarse and deep, irregular splitting of the high parasutural membranes. Septures of the letter subspecies are lower, are nearly constant in height, and are finely distally denticulated.

Two types of parasutural septa variations are now known: (1) the successive reduction of membrane height from $M$. perforata ssp. mirabilis to $M$. perforata ssp. perforata; (2) the second type is the interruption of membranes by deep splits and consequently the total absence of membranes between gonal thickenings, as occurs in the range of variation between $M$. perforata ssp. mirabilis and M. chleuh Below, 1981.

Occurrence. See Figure 1, No. 140: Sample 545-39-4, 94-97 cm to Sample 545-31-1, 130-133 cm, late Albian, basal and early Cenomanian; Figure 3, No. 32: Sample 549B-5-6, 50-53 cm to Sample 549B-2-2, 0-2 cm, late Albian; Figure 4, No. 9, Sample 549A-73-1, 148-150 cm to Sample $547 \mathrm{~A}-48-2,75-77 \mathrm{~cm}$, late Albian to basal Cenomanian.

\section{Genus OCCISUCYSTA Gitmez, 1970}

Type species. Occisucysta balios Gitmez, 1970.

Junior synonym. Diacanthum Habib, 1972.

Diagnosis. Gitmez 1970, p. 267.

\section{Occisucysta hinzii n.sp.}

(Plate 6, Figs. 7, 8; text, Fig. 6)

Derivatio nominis. In honor of Dr. Karl Hinz, Co-Chief Scientist of Leg 79.

Diagnosis. Large, proximate, two-layered, cornucavate, oval cyst with broad, pyramidal apical horn. Periphragma irregularly thickened to alveolate or forming a reticulum with muri and soli of variable width and shape. Very sparsely granulated. Endophragma thin, finely perforated. Paratabulation goniaulacacean ?PR, $4^{\prime}, 6^{\prime}$ ', Xc, as, ra, Is, rs, pv, $6^{\prime \prime}, 11^{\prime \prime \prime}$. Parasutures marked by low, thick ridges that can expand to low septa. The hypocyst is distorted against the epicystal plate series so that $3^{\prime \prime \prime} / 4^{\prime \prime \prime}$ parasuture is mid-dorsal. Intratabular pseudosutures occasionally present. Archeopyle $2 \mathrm{P}_{2}{ }^{\prime \prime}-3{ }^{\prime \prime}$.

Holotype. Slide IV 6938: 41.4/101.

Type locality. DSDP Leg 79, 545-45-4, 40-43 cm, Mazagan Plateau, off Northwest Africa.

Type level. late Aptian.

Dimensions. Holotype: length $78 \mu \mathrm{m}$, breadth $67 \mu \mathrm{m}$, length of endocyst $60 \mu \mathrm{m}$, height of septa up to $3 \mu \mathrm{m}$; other specimens: length $72-104 \mu \mathrm{m}$, length of endocyst $60-86 \mu \mathrm{m}$, width $60-84 \mu \mathrm{m}$, height of septa up to $4 \mu \mathrm{m}$.

Description. The large, two-layered cyst has a basically oval ambitus with an obvious, broad-based, hollow, equilateral pyramidal apical horn, which is positioned slightly off the anterior cyst pole and displaced in ventral direction (Plate 6, Fig. 8). The two cyst wall layers are closely attached, except at the apex where the outer layer forms the cornucavate apical protuberance. The periphragma is irregularly thickened and so gives rises to uneven, broad and high muri around soli of variable size and form (Fig. 6). Under light microscopy, the cyst wall appears alveolate. A few specimens show special thickenings of the muri to small intraparatabular pseudosutures, as described for Occisucysta brixii Below (1982a), or thickenings of intrabular areas as shown for Occisucysta evittii (Dodekova, 1969) Gitmez, 1970 by Below (1982a). General reduction of periphragmal structures is possible. Occasional specimens show nodes and tubercles as relicts of muri on a smooth or finely reticulated periphragma. The endophragma is smooth to finely reticulated. The cyst wall has low, thick parasutural ridges or-on a few

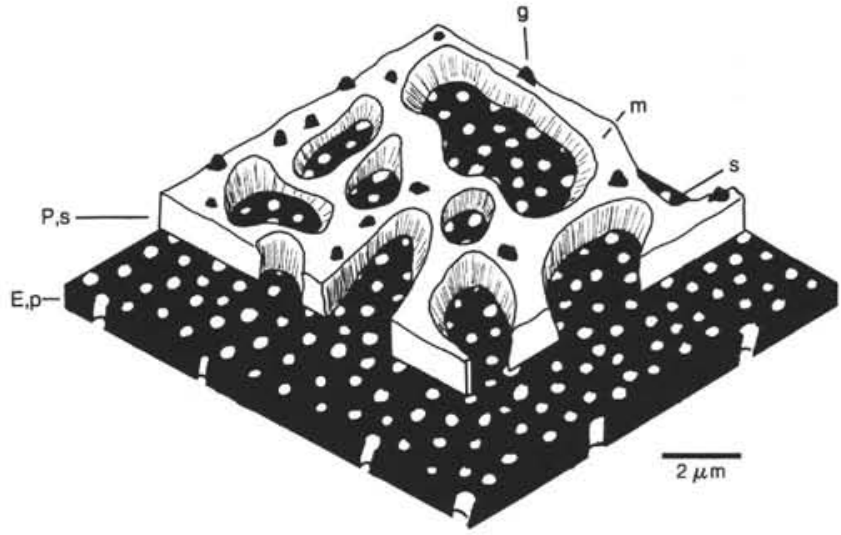

Figure 6. Occisucysta hinzii n.sp. detail of cystwall; E,p = perforated endophragma; $\mathrm{P}, \mathrm{s}=$ solid periphragma; $\mathrm{g}=$ granulae; $\mathrm{m}=$ muri; $\mathrm{s}$ = solum.

specimens-narrow, perforated parasutural septa that are best developed around the antapex. The paratabulation is typically goniaulacacean. Preapical paraplates cannot be observed with absolute assurance, but there are faint lines on the apical horn that imply the existence of a top preapical $1 P R$ and a second $2 P R$ on the dorsal side of the horn. Four apical paraplates can be distinguished, a small, long $1^{\prime}$, pentagonal $2^{\prime}$ and $3^{\prime}$ and the rhombic $4^{\prime}$ that fills the angle between $5^{\prime \prime}$ and $6{ }^{\prime \prime}$. The precingular series are trapezoidal or pentagonal and of equal size, except for the smaller $6^{\prime \prime}$ '. The equatorially situated paracingulum is offset by its width at the parasulcus with its first and last paraplate bent posteriorly. The postcingular series begins with a small rectangular $1^{\prime \prime \prime}$. This is poorly separated from the parasulcus by a parasutural rib, but differs by its alveolate texture from the smooth $1 s$. The postcingular series continues with the equilaterally triangular $2^{\prime \prime \prime}$ and the trapezoidal $3^{\prime \prime \prime}$ to $6^{\prime \prime \prime}$. The pv paraplate is very elongated and poorly defined against pr, ps, and ls, because of the absence of parasutural ridges. In the parasulcus it is possible to distinguish the elongated smooth ls, a long rs and an arrowshaped ps that is bent into a small antapical $1{ }^{\prime \prime} \prime \prime$. Paraplate series of epicyst and hypocyst are distorted as in Cribroperidinium (Gocht, 1979; Below, 1981), so that the $3^{\prime \prime \prime} / 4^{\prime \prime \prime}$ boundary is mid-dorsal. The archeopyle-type is $2 \mathrm{P}_{2^{\prime \prime}-3^{\prime \prime}}$, but in some specimens paraplate $1^{\prime \prime}$ and/ or $4^{\prime \prime}$ are lost also.

Comparison. The irregularly thickened cyst wall with various shapes of muri and soli is unique among species of the genus Occisucysta.

Occurrence. see Figure 1, No. 99: Sample 545-49-5, 49-52 cm to Sample 545-44-2, 78-82 cm; middle to late Aptian.

Occisucysta mazaganensis n.sp.

(Plate 6, Fig. 9; Plate 7, Fig. 1; text, Fig. 7)

Derivatio nominis. Mazagan, town in Morocco. DSDP Leg 79 Sites are situated near submarine Mazagan Plateau.

Diagnosis. Large, proximate, spheroidal, two-layered, acavate or cornucavate cyst with a low apical bulge. Endophragma smooth, periphragma reticulated, bearing solid, irregularly interconnected spines that are strung together on parasutures. Paratabulation goniaulacacean ?XPR, $4^{\prime}, 6^{\prime \prime}, \mathrm{Xc}$, as, rs, 1s, ps, pv, $6^{\prime \prime \prime}, 1^{\prime \prime}{ }^{\prime \prime}$, with torsion of hypocyst against epicyst so that the 3 ' $^{\prime \prime} / 4^{\prime \prime}$ ' paraplate boundary is mid-dorsal. One or two additional, isolated, solid spines per paraplate. Archeopyle type $2 \mathrm{P}_{2^{\prime \prime}-3}{ }^{\prime \prime}$.

Holotype. Slide III-6879: 40.6/107.7.

Type locality. DSDP Leg 79, 547B-5-5, 100-103 cm; Mazagan Plateau, off Northwest Africa.

Type level. late Albian.

Dimensions. Holotype: length $86 \mu \mathrm{m}$, breadth $72 \mu \mathrm{m}$, length of spines $6 \mu \mathrm{m}$ to $10 \mu \mathrm{m}$; other specimens: length $78-95 \mu \mathrm{m}$, breadth 68-81 $\mu \mathrm{m}$, length of spines 2-12 $\mu \mathrm{m}$.

Description. The large, two-layered cyst has an overall oval to subspheroidal ambitus. It tapers apically, forming an apical horn or a low, apical bulge. The smooth endophragma and the reticulated peri- 


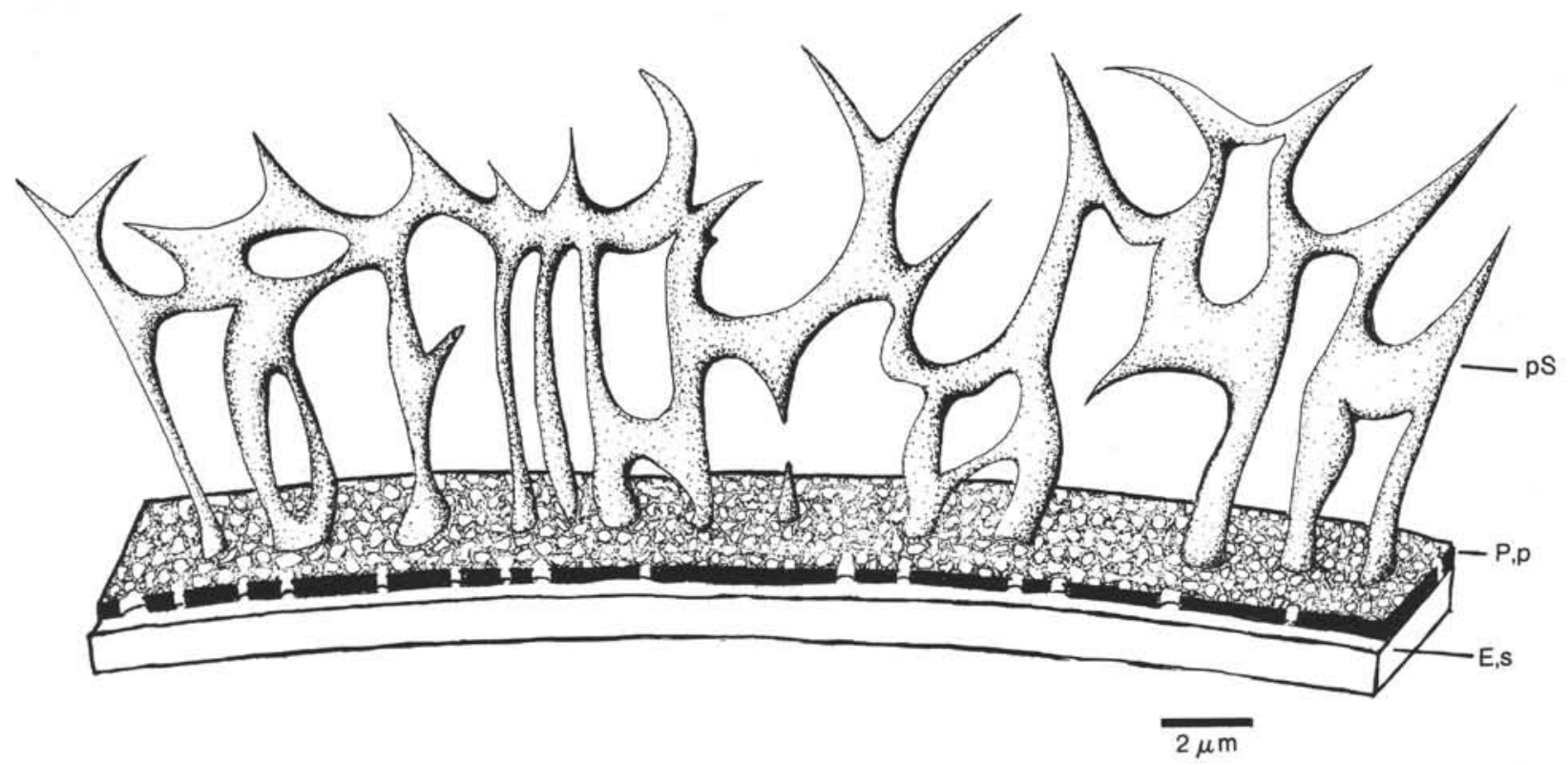

Figure 7. Occisucysta mazaganensis $\mathrm{n} . \mathrm{sp}$., detail of cystwall; $\mathrm{E}, \mathrm{s}=$ solid endophragma; $\mathrm{P}, \mathrm{p}=$ perforated periphragma; $\mathrm{pS}=$ parasutural spine row.

phragma are attached. Only in a few cases do they form a cornucavate pericoel in the apical region. The cyst wall gives rise to solid acuminate spines of varying height and width, which are arranged on parasutures. Spines are irregularly connected at different heights (Fig. 7). Generally, there are one or two solid, acuminate intratabular spines in the center of most paraplates. A goniaulacacean paratabulation is defined: ?XPR, $4^{\prime}, 6^{\prime \prime}, \mathrm{Xc}$, as, rs, ls, ps, pv, $6^{\prime \prime}{ }^{\prime}, 1^{\prime \prime \prime}{ }^{\prime \prime}$. The preapical plates are difficult to distinguish because the apical horn builds a complicated trestle, formed by the junctions of the parasutural spine-rows between apical paraplates. Nevertheless, the crownlike morphology of the apical horn tip implies the existence of such preapical paraplates. The apical series is comprised of a narrow, long $1^{\prime}$, pentagonal 2 ' and $3^{\prime}$ and a rhombic 4'. Paraplate 4' fills the angle between $5^{\prime \prime}$ and 6', as is typical for the species of the genus Occisucysta. The paraplates of the precingular series are trapezoidal or pentagonal and equally large, except for the smaller pentagonal $6^{\prime \prime}$. The equatorially situated paracingulum is offset by its width at the parasulcus. In contrast to other paraplates, the paracingulum bottom is built up of a very coarse periphragmal net. The postcingular series begins with a small rectangular 1" "and continues with the equilateral triangular 2'" and trapezoidal $3^{\prime \prime \prime}$ to $6^{\prime \prime \prime}$. The pv plate is elongate and polygonal. In the parasulcus, it is possible to observe the anterior/posteriorly elongated rs and ls and an arched ps. The trapezoidal $1^{\prime \prime \prime}$ ' is indented by this ps paraplate. Epicyst and hypocyst series are distorted so that the $3^{\prime \prime \prime} / 4^{\prime \prime \prime}$ boundary is mid-dorsal. Archeopyle type $2 \mathrm{P}_{2}{ }^{\prime \prime}-3^{\prime \prime}$.

Comparison. The irregularly connected rows of parasutural spines, which look like a crown of thorns, are typical for this species, which resembles only Occisucysta paucispina (Eisenack and Cookson, 1960) Below, 1981. This species has few parasutural spines which are not connected or are only basally interconnected.

Occurrence. See Figure 1, No. 143: Sample 545-39-1, 93-96 cm, late Albian; Figure 3, No. 33: Sample 547B-5-6, 50-53 cm to Sample 547B-2-2, 0-2 cm, late Albian.

\section{Genus OLIGOSPHAERIDIUM Davey and Williams, 1966}

Type species. Oligosphaeridium complex (White, 1842) Davey and Williams 1966.

Diagnosis. Davey and Williams, 1966b, p. 70.

\section{Oligosphaeridium verrucosum Davey, 1979} (Plate 7, Figs. 11, 12, 13)

Remarks. Oligosphaeridium verrucosum, a very large species, tends to show a greater degree of variability in cyst wall ornamentation than other species of the genus Oligosphaeridium. Within the same population one can observe specimens with either dense or sparse distribution of large granulae; or individuals with a very dense but fine granulation; or specimens with a scabrate or smooth cyst wall.

Occurrence. See Figure 1, No. 80: Sample 545-52-2, 123-126 cm to Sample 545-47-6, 72-75 cm; middle to late Aptian.

Genus SPINIFERITES Mantell, 1850, emend. Sarjeant, 1970

Type species. Spiniferites ramosus (Ehrenberg, 1838) Loeblich and Loeblich, 1966.

Diagnosis. Mantell, 1850, p. 191: Sarjeant, 1970, p. 75.

\section{Spiniferites cf. wetzelii (Deflandre, 1937) Sarjeant, 1970 (Plate 9, Fig. 15)}

Remarks. This species is characterized by high parasutural septa between the gonal processes. These processes are only slightly higher than the parasutural membranes and are distally bifurcated or trifurcated. In contrast to the typical Spiniferites wetzelii with distally smooth septa, the membranes of the species discussed here have broad but bifurcate appendages.

Occurrence. See Figure 1, No. 89: Sample 545-51-1, 47-50 cm, middle Aptian; Figure 3, No. 46: Sample 547B-5-5, 100-103 cm to Sample 547B-5-1, 0-3 cm, late Albian.

\section{Genus SYSTEMATOPHORA Klement, 1960}

Type species. Systematophora areolata Klement, 1960. Diagnosis. Klement, 1960, p. 61.

\section{Systematophora? sp. MAZ \\ (Plate 10, Fig. 2: text, Fig. 8)}

Description. Spheroidal, two-layered chorate cyst. Endophragma smooth, periphragma finely fibrous, especially where forming processes. Processes of one individual are all of equal length-corresponding to half the cyst body diameter but of somewhat unequal diameter. The processes are hollow and are either tubiform or distally somewhat widened. The process wall is made up of very fine fibers which are irregularly connected to a fine-meshed net. The distal process margins are deeply split. A few thin, simple, solid appendages are present. The arrangement of processes is unknown and reconstruction of paratabulation is therefore impossible. Archeopyle unknown.

Remarks. There are too few well preserved and favorably oriented specimens to formally erect a new species. Nevertheless, this striking cyst is a typical component of some Aptian and Cenomanian dinoflagellate cyst assemblages. 


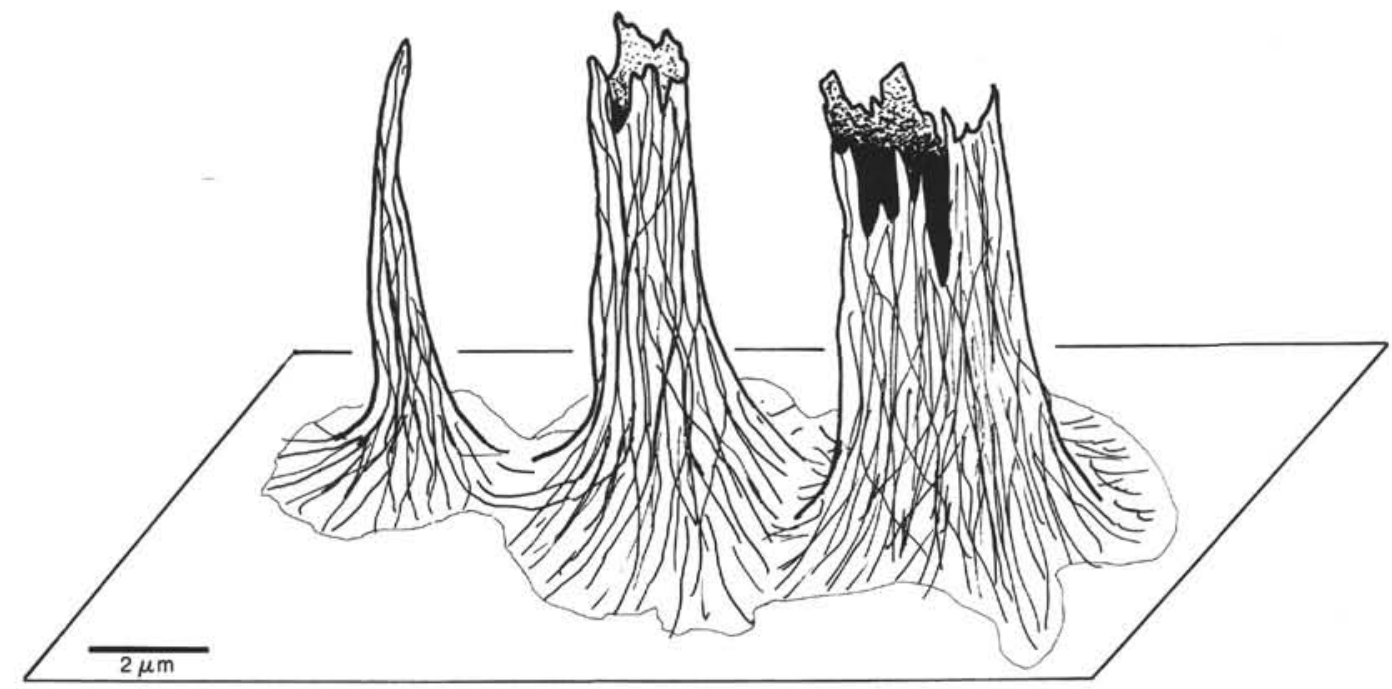

Figure 8. Systematophora? $s p$. MAZ, fibrous processes of variable morphology.

Occurrence: See Figure 1, No. 91: Sample $545-50-6,56-58 \mathrm{~cm}$ to Sample 545-33-1, 90-94 cm, middle and late Aptian, basal Cenomanian; Figure 4, No. 63: Sample 547-63-2, 0-2 cm, basal Cenomanian.

\section{ACKNOWLEDGMENTS}

I wish to acknowledge Prof. H. K. Erben and Prof. K. J. Müller, directors of the Institut für Paläontologie, Rheinische Friedrich-Wilhelms Universität Bonn, who made working facilities and material available to me. Acids used in the palynological preparation were donated by BAYER AG, Leverkusen.

I would also express my thanks to Dr. $\mathrm{H}$. Gocht, Tübingen, and Dr. J. Jansonius, Calgary, for critically reading the manuscripts and to Mrs. B. Martin, Bonn, for revising the English.

Financial support was given by the Heinrich-Hörlein-Stiftung of the Fachgruppe Erdwissenschaften, Rheinische Feridrich-Wilhelms Universität Bonn.

\section{REFERENCES}

Alberti, G., 1961. Zur Kenntnis mesozoischer und alt-tertiarer Dinoflagellaten und Hystrichosphaerideen von Nord- und Mitteldeutschland sowie einigen anderen europäischen Gebieten. Palaeontographica, $A, 116: 1-58$.

Below, R., 1981. Dinoflagellaten-Zysten aus dem oberen Hauterive bis unteren Cenoman Süd-West-Marokkos. Palaeontographica, B, 176: 1-145.

, 1982a. Scolochorate Zysten der Gonyaulacaceae (Dinophyceae) aus der Unterkreide Marokkos. Palaeontographica, B, 182: $1-51$.

1982b. Dinoflagellate cysts from the Valanginian to lower Hauterivian of sections near Ait Hamouch/Morocco. Rev Espan. Micropaleontol, 14:23-52.

Brideaux, W. W., 1971. Palynology of the Lower Colorado Group, central Alberta, Canada, I. Introductory remarks. Geology and microplankton studies. Palaeontographica, B, 135:53-114.

Brideaux, W. W., and McIntyre, D. J., 1975. Miospores and microplankton from Aptian-Albian rocks along Horton River, District of Mackenzie. Geol. Surv. Can. Bull., 252:1-85.

Clarke, R. F. A., Davey, R. J., Sarjeant, W. A. S., and Verdier, J.-P., 1968. A note on the nomenclature of some Upper Cretaceous and Eocene dinoflagellate taxa. Taxon, 17:181-183.

Clarke, R. F. A., and Verdier, J.-P., 1967. An investigation of microplankton assemblages from the Chalk of the Isle of Wight, England. K. Nederl. Akad. Wetensch. Afd. Nat. Eerste Reeks, 24: $1-96$.

Cookson, I. C., and Eisenack, A., 1958. Microplankton from Australian and New Guinea Upper Mesozoic sediments. Proc. R. Soc. Victoria, 70:19-79.
1960. Upper Mesozoic microplankton from Australia and New Guinea. Palaeontology, 2:243-261.

1962. Additional microplankton from Australian Cretaceous sediments. Micropaleontology, 8:485-507.

1974. Mikroplankton aus Australischen Mesozoischen und Tertiären Sedimenten. Palaeontographica, B, 148:44-93.

Cookson, I. C., and Hughes, N. F., 1964. Microplankton from the Cambridge Greensand (mid-Cretaceous). Palaeontology, 7:37-59.

Davey, R. J., 1969. Non-calcareous microplankton from the Cenomanian of England, northern France and North America, Part I. Bull. Brit. Mus. Nat. Hist., Geol., 17:1-11.

, 1974. Dinoflagellate cysts from the Barremian of the Speeton clay, England. Symp. Stratig. Palynol. Birbal Sahni Inst. Palaeobot., Spec. Publ., 3:41-75.

1978. Marine Cretaceous palynology of Site 361 , DSDP Leg 40, off southwest Africa. In Bolli, H. M., Ryan, W. B. F., et al., Init. Repts. DSDP, 40: Washington (U.S. Govt. Printing Office), 883-913.

1979. Marine Apto-Albian palynomorphs from Holes 400A and 402A, IPOD Leg 48, northern Bay of Biscay. In Montadert, L., Roberts, D. G., et al., Init. Repts. DSDP, 48: Washington (U.S. Govt. Printing Office), 547-577.

Davey, R. J.,-Downie, C., Sarjeant, W. A. S., and Williams, G. L., 1966. Fossil dinoflagellate cysts attributed to Baltisphaeridium. Bull. Brit. Mus. Nat. Hist., Geol., Suppl., 3:157-175.

Davey, R. J., and Verdier, J. P., 1971. An investigation of microplankton assemblages from the Albian of the Paris Basin. Verh. K. Nederl. Akad. Wetensch. Afd. Nat., Eerste Reeks, 26:1-58.

1973. An investigation of microplankton assemblages from latest Albian (Vraconian) sediments. Rev. Esp. Micropaleontol., 5:173-212.

1974. Dinoflagellate cysts from the Aptian type sections at Gargas and La Bédoule, France. Palaeontology, 17:623-653.

1976. A review of certain non-tabulate Cretaceous hystrichospherid dinocysts. Rev. Palaeobot. Palynol., 22:307-335.

Davey, R. J., and Williams, R. J., 1966a. The genera Hystrichosphaera and Achomosphaera. Bull. Brit. Mus. Nat. Hist., Geol., Suppl., $3: 28-52$.

1966b. The genus Hystrichosphaeridium and its allies. Bull. Brit. Mus. Nat. Hist., Geol., Suppl., 3:53-106.

1969. Generic reallocations. Bull. Brit. Mus. Nat. Hist., Geol., Appendix to Suppl. 3:4-7.

Deflandre, G., 1935. Considérations biologiques sur les microorganisms dorigine planctonique conservés dans les silex de la craie. Bull. Biol. France Belg., 69:213-244.

1936. Microfossiles des silex crétacés. Première partie. Généralités Flagellés. Ann. paleontol., 25:151-191. 
1937. Microfossiles des silex crétacés. Deuxième partie. Flagellés incertae sedis Hystrichosphaeridés, Sarcodinés, Organismes divers. Ann. paléontol., 26:51-103.

Deflandre, G., and Cookson, I. C., 1955. Fossil microplankton from Australian Late Mesozoic and Tertiary sediments. Aust. J. Mar. Freshwater Res., 6:242-313.

Deflandre, G., and Courteville, H., 1939. Note préliminaire sur les microfossiles des silex crétacés du Cambrésis. Bull. Soc. fran. Microscop., 8:95-106.

Dörhöfer, G., and Davies, E. H., 1980. Evolution of Archeopyle and Tabulation in Rhaetogonyaulacinean Dinoflagellate Cysts. R. Ont. Mus. Life Sci. Misc. Publ.

Downie, C., and Sarjeant, W. A. S., 1965. Bibliography and Index to Fossil Dinoflagellates and Acritarchs. Geol. Soc. Am. Mem. 94.

Drugg, W. S., 1978. Some Jurassic dinoflagellate cysts from England, France and Germany. Palaeontographica, B, 168:61-79.

Duxbury, S., 1977. A palynostratigraphy of the Berriasian to Barremian of the Speeton Clay of Speeton, England. Palaeontographica, $B, 160: 17-67$.

1979. Three new genera of dinoflagellate cysts from the Speeton Clay (Early Cretaceous) of Speeton, England. Micropaleontology, 25:198-205.

, 1980. Barremian phytoplankton from Speeton, east Yorkshire. Palaeontographica, $B, 173: 107-146$.

Ehrenberg, C. G., 1838. Über das Massenverhältniss der jetzt lebenden Kiesel-Infusorien und über ein neues Infusorien-Conglomerat als Polirschiefer von Jastraba in Ungarn. Abh. Preuss. Akad. Wiss., 1836, pp. 109-135.

Eisenack, A., 1958. Mikroplankton aus dem norddeutschen Apt. $N$. Jb. Geol. Pal. Abh., 106:383-422.

Eisenack, A., and Cookson, I. C., 1960. Microplankton from Australian Lower Cretaceous sediments. Proc. $R$. Soc. Victoria, 72:1-11.

Eisenack, A., and Kjellström, G., 1971. Katalog der Fossilen Dinoflagellaten, Hystrichosphaeren und Verwandten Mikrofossilien. Band II, Dinoflagellaten: Stuttgart (E. Schweizerbart'sche Verlagsbuchhandlung).

Evitt, W. R., 1963. A discussion and proposals concerning fossil dinoflagellates, hystrichosphaeres, and acritarchs, I. Proc. Nat. Acad. Sci., Washington, 49:158-164.

Gerlach, E., 1961. Mikrofossilien aus dem Oligozän und Miozän Nordwestdeutschlands, unter besonderer Berücksichtigung der Hystrichosphaeren und Dinoflagellaten. N. Jb. Geol. Pal., Abh., 112: 143-228.

Gitmez, G. U., 1970. Dinoflagellate cysts and acritarchs from the basal Kimmeridgian (Upper Jurassic) of England, Scotland, and France. Bull. Brit. Mus. Nat. Hist. Geol., 18:231-331.

Gocht, H. 1957. Mikroplankton aus dem nordwestdeutschen Neokom (Teil I). Pal. Z., 31:163-185.

1959. Mikroplankton aus dem nordwestdeutschen Neokom (Teil II). Pal. Z., 33:50-89.

Habib, D., 1972. Dinoflagellate stratigraphy Leg 11, Deep Sea Drilling Project. In Hollister, C. D., Ewing, J. I., et al., Init. Repts. $D S D P, 11$ : Washington (U.S. Govt. Printing Office), 367-425.

1976. Neocomian dinoflagellate zonation in the western North Atlantic. Micropaleontology, 21:373-392.

Hasenboehler, B., in press. Trois espèces nouvelles de Dinoflagéllés dans l'Albien et le Cenomanien de l'Estrémadura (Portugal). Z. Rev. Micropaleontol.

Jain, K. P., 1977. Additional dinoflagellates and acritarchs from Grey Shale Member of Dalmiapuram Formation, south India. Palaeobotanist, 24:170-194.

Jain, K. P., and Millepied, P., 1973. Cretaceous microplankton from Senegal Basin, N.W. Africa. 1. Some new genera, species and combinations of dinoflagellates. Palaeobotanist, 20:22-32.

Klement, K. W., 1960. Dinoflagellaten und Hystrichospaerideen aus dem unteren und mittleren Malm Südwestdeutschlands. Palaeontographica, A, 114:1-104.

Lentin, J. K., and Williams, G. L., 1973. Fossil Dinoflagellates: Index to Genera and Species. Geol. Surv. Can. Paper 73-42.
1976. A Monograph of Fossil Peridinoid Dinoflagellate Cysts. Bedord Inst. Oceanogr. Rept. BI-R-75-16. 1977 (1981). Fossil Dinoflagellates: Index to Genera and Species. 1977 Ed. Bedford. Inst. Oceanogr. Rept. BI-R-77-8 (1981 Ed., BI-R-81-12).

Lentin, J. K., and Williams, G. L., 1981. Fossil Dinoflagellates: Index to Genera and Species (1981 Ed.). Bedford Inst. Oceanogr. Rept. BI-R-81-12.

Loeblich, A. R., Jr., and Loeblich, A. R., III, 1966. Index to the Genera, Subgenera, and Sections of the Pyrrhophyta. Stud. Trop. Oceanogr., Miami, 3.

Maier, D., 1959. Planktonuntersuchungen in tertiären und quartären marinen Sedimenten. Ein Beitrag zur Systematik, Stratigraphie, und Ökologie der Coccolithophorideen, Dinoflagellaten, und Hystrichosphaerideen vom Oligozän bis zum Pleistozän. $N$. Jb. Geol. Pal., Abh., 107:278-340.

Mantell, G. A., 1850. A Pictorial Atlas of Fossil Remains Consisting of Coloured Illustrations Selected from Parkinson's "Organic Remains of a Former World", and Artis's "Antediluvian Phytology": London, (Henry G. Bohn).

Manum, S. and Cookson, I. C., 1964. Cretaceous microplankton in a sample from Graham Island, Arctic Canada, collected during the second Fram - Expedition (1898-1902). With notes on microplankton from the Hazzel Formation, Ellef Ringnes Island. Schrift. Norske Videnskaps-Akademi Oslo, I. Mat.-Naturv. Klasse, Ny Series, 17: $1-35$.

Millioud, M. E., 1969. Dinoflagellates and acritarchs from some western European Lower Cretaceous type localities. Proc. First Int. Conf. Planktonic Microfossils, Geneva, 1967, 2:420-434.

Neale, J. W., and Sarjeant, W. A. S., 1962. Microplankton from the Speeton Clay of Yorkshire. Geol. Mag., 99:439-458.

Norvick, M. S., 1976. Mid-Cretaceous microplankton from Bathurst Island. Aust. Bur. Miner. Res., Geol. Geophys. Bull. 151:21-113.

Pocock, S. A. J., 1962. Microfloral analysis and age determination of strata at the Jurassic-Cretaceous boundary in the western Canada plains. Palaeontographica, $B, 111: 1-95$.

Sarjeant, W. A. S., 1966a. Dinoflagellate cysts with Gonyaulax-type tabulation. Bull. Brit. Mus. Nat. Hist., Geol., Suppl., 3:107-156. 1966b. Further dinoflagellate cysts from the Speeton Clay. Bull. Brit. Mus. Nat. Hist., Geol., Suppl., 3:199-214. 1969. Taxonomic changes. Bull. Brit. Mus. Nat. Hist., Geol., Appendix to Suppl., 3:7-15.

1970. The genus Spiniferites Mantell, 1850 (Dinophyceae). Grana, 10:74-78.

Singh, C., 1964. Microflora of the Lower Cretaceous Mannville Group, east-central Alberta. Res. Counc. Alberta, Bull., 15:1-239.

Stover, L. E., and Evitt, W. R., 1978. Analysis of pre-Pleistocene organic-walled dinoflagellates. Stanford Univ. Publ., Geol. Sci., 15: $1-300$.

Wetzel, O., 1933. Die inorganischer Substanz erhaltenen Mikrofossilien des baltischen Kreide-Feuersteins mit einem sedimentpetrographischen und stratigraphischen Anhang. Palaeontographica, $A$, 77:141-188.

White, H. H., 1842. On fossil Xanthidia. Microsc., London, 11:35-40.

Williams, G. L., 1975. Dinoflagellate and spore stratigraphy of the Mesozoic-Cenozoic, offshore eastern Canada. Geol. Surv. Can., Paper 74-30, 2:107-161.

1978. Palynological biostratigraphy, Deep Sea Drilling Project, Sites 367 and 370, Leg 41. In Lancelot, Y., Seibold, E., et al., Init. Repts. DSDP, Suppl. to Vols. 38-41: Washington (U.S. Govt. Printing Office), 783-815.

Valensi, L., 1955. Sur quelques microorganismes des silex crétacés du Magdalénien de Saint-Amand (Cher). Bull. Soc. Géol. France, Ser. 6., 5:35-40.

Yun, H.-S., 1981. Dinoflagellaten aus der Oberkreide (Santon) von Westfalen. Palaeontographica, B, 177:1-89.

Date of Initial Receipt: November 23, 1982

Date of Acceptance: July 6, 1983 


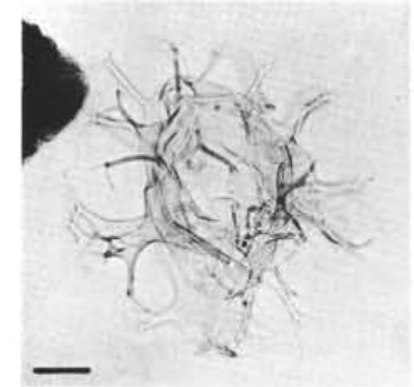

1

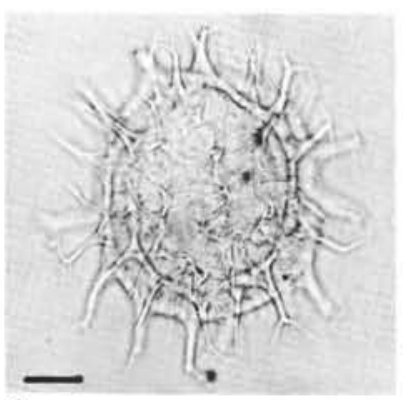

4

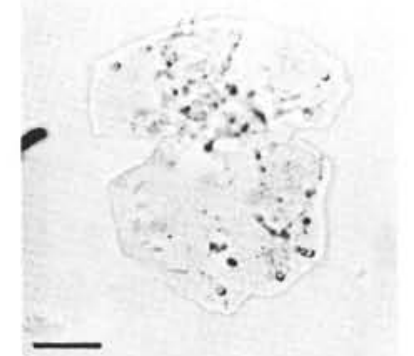

7

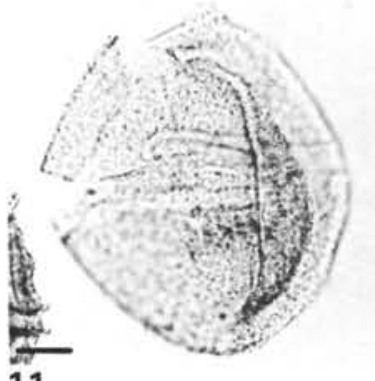

11

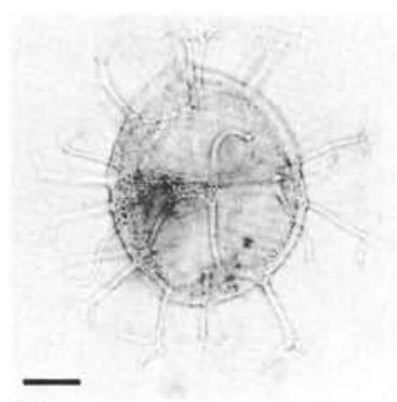

$2 A$

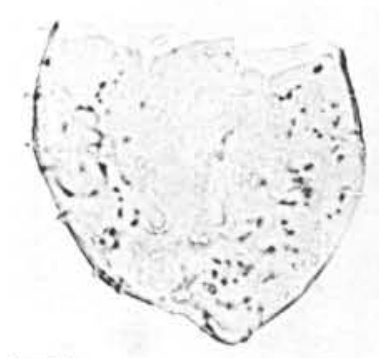

$5 A$

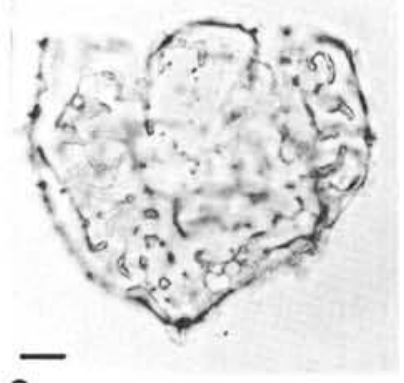

8

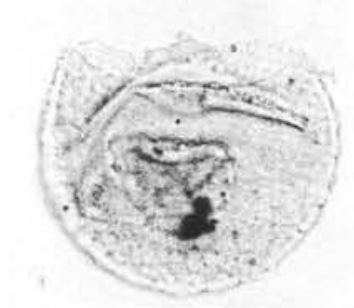

12

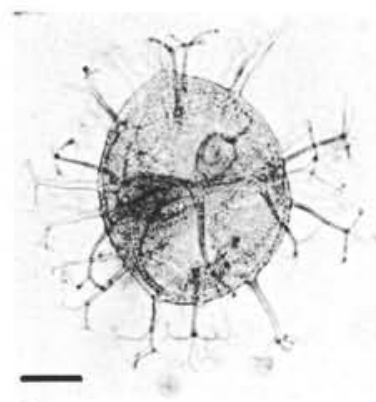

2B

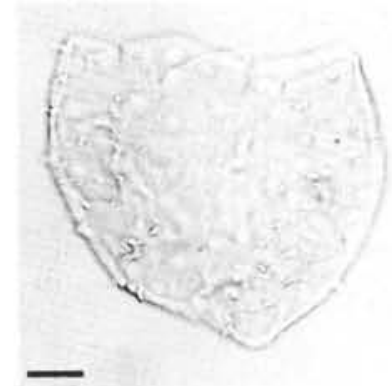

5B
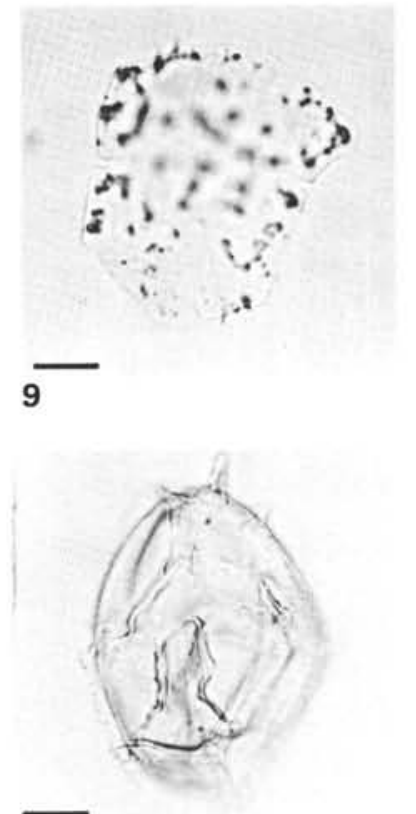

13
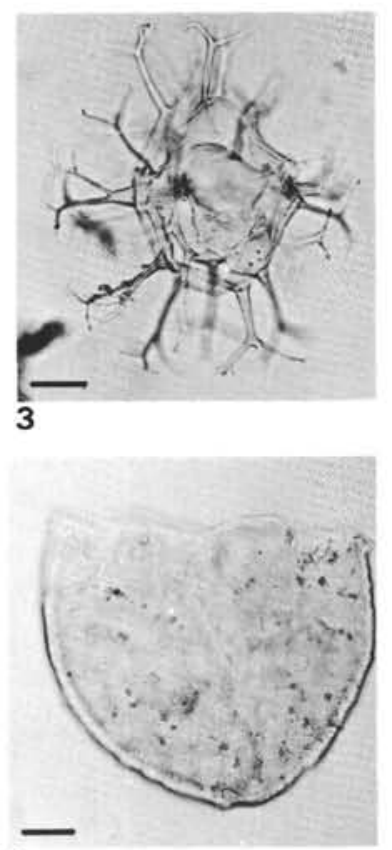

6
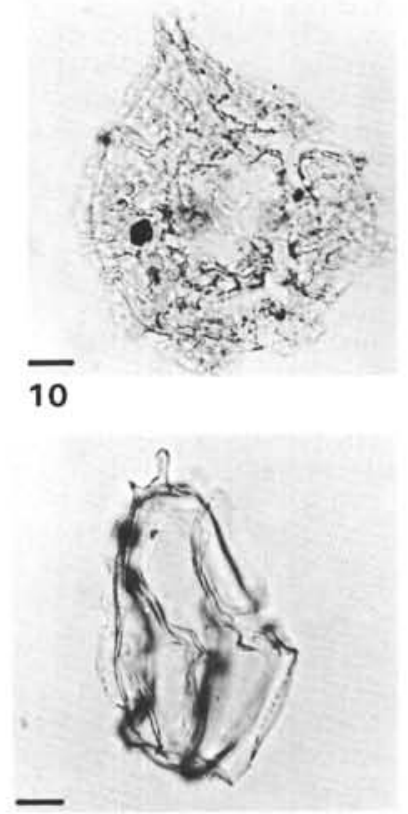

14

Plate 1. (Scale bar $=10 \mu \mathrm{m}$.) 1. Achomosphaera ramulifera, length $66 \mu \mathrm{m}$, oblique cingular view; slide II-6909: 22.1/98, Sample 547A-63-4, $46-48 \mathrm{~cm}$. 2. Achomosphaera sagena, length $70 \mu \mathrm{m}$, oblique cingular view with different focus; slide II-6889: $30.9 / 108.1$, Sample 547A-48-2, $75-77 \mathrm{~cm}$. 3. Achomosphaera triangulata, length $72 \mu \mathrm{m}$, oblique cingular view; slide II-6898: 45/105.4; Sample 547A-56-2, 48-51 cm. 4. Achomosphaera verdieri, length $56 \mu \mathrm{m}$, oblique cingular view; slide I-6954: 32.7/99.2; Sample 545-55-1, 60-62 cm. 5-7. Aptea almohadensis n.sp., (5) breadth $70 \mu \mathrm{m}$, holotype; dorso-ventral orientation, (A, circular focus; B, ventral focus), slide II-9646: 49.6/100.4, Sample 545-49-5, 49-52 cm; (6) breadth $75 \mu \mathrm{m}$; specimen with few and very low ornaments; slide III-9644: 29.2/99.3, Sample 545-48-6, 16-18 cm; (7) breadth of operculum $45 \mu \mathrm{m}$; operculum consists of four apical paraplates; slide II-6946: 40,8/103,3, Sample 545-49-5, 49-52 cm. 8-9. Aptea eisenackii, (8) breadth $77 \mu \mathrm{m}$, ventral focus, slide I-6951: 45/109.6, Sample 545-52-2, 123-126 cm; (9) breadth of operculum $45 \mu \mathrm{m}$, apical view; note splits along parasutures between the four apical paraplates, slide II-6944: 47.5/104.4, Sample 545-48-6, 16-18 cm. 10. Aptea polymorpha, length 96 $\mu \mathrm{m}$, dorsal focus, slide I-6955: 54.9/106.4, Sample 545-59-6, 71-73 cm. 11. Apteodinium maculatum, length $72 \mu \mathrm{m}$, oblique view, slide I-6938: $27 / 105.2$, Sample $545-45-4,40-43 \mathrm{~cm}$. 12. Batiacasphaera saidensis, breadth $60 \mu \mathrm{m}$, operculum inside the vesicle, ventral focus, slide I-6931: $40.3 / 113.5$, Sample 545-41-1, 47-49 cm. 13-14. Carpodinium granulatum, (13) length $60 \mu \mathrm{m}$, ventral focus, slide III-6946: 43.8/103.2, Sample 545-49-5, 49-52 cm; (14) length $78 \mu \mathrm{m}$, oblique cingular view, slide I-6942: 41.4/112.7, Sample 545-47-6, 72-75 cm. 


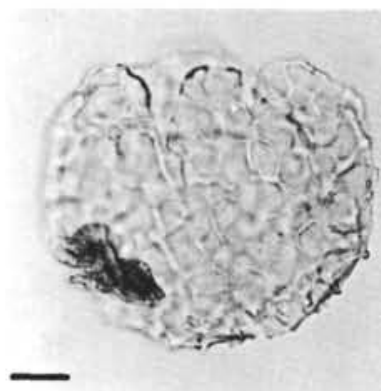

1

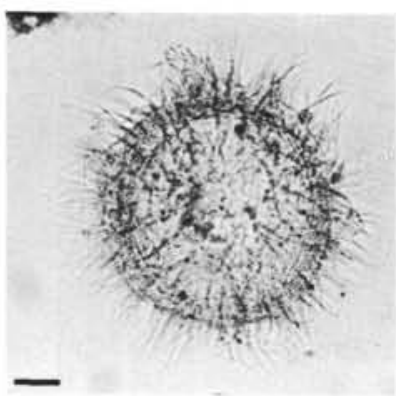

$\overline{4}$

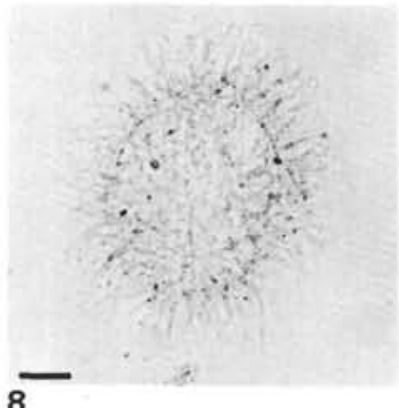

8

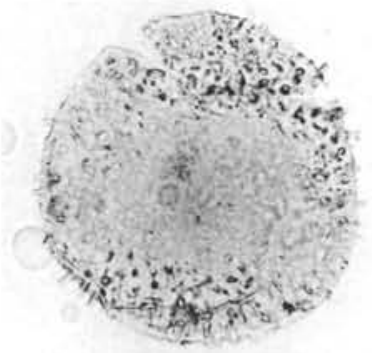

12
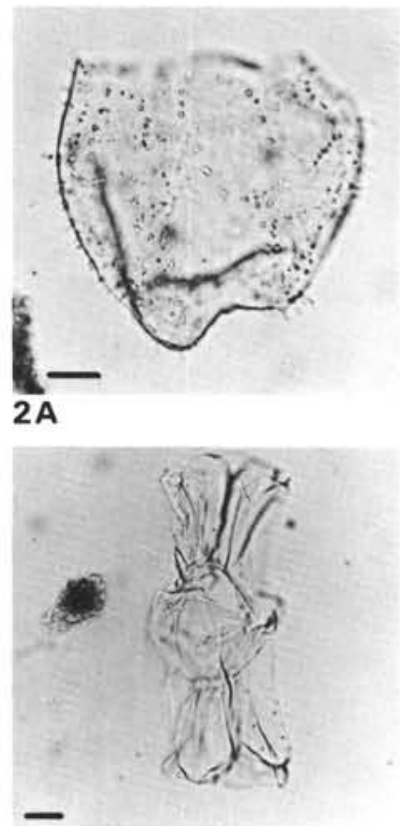

5

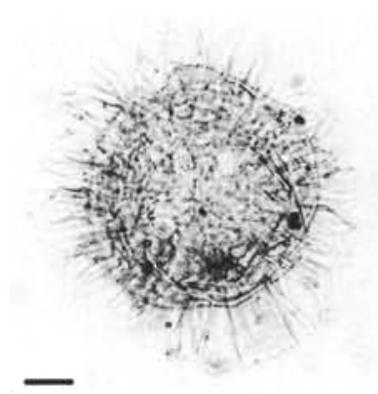

9

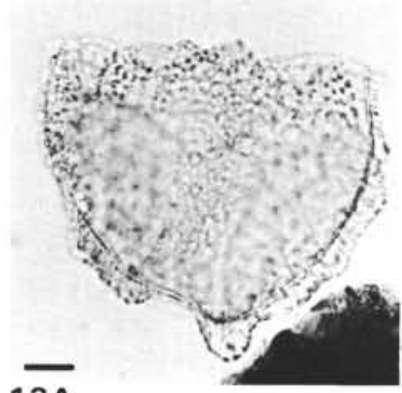

$13 \mathrm{~A}$

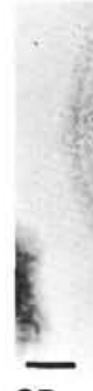

2B

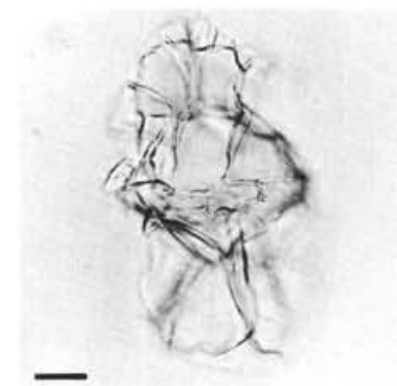

6

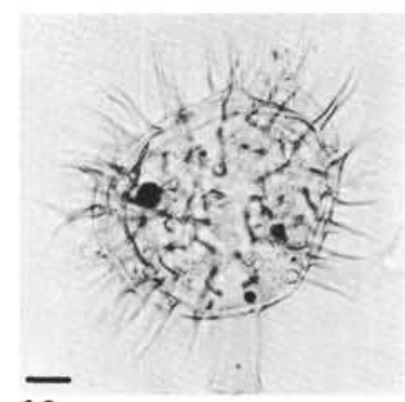

10

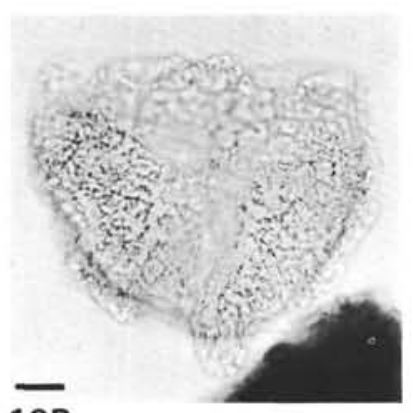

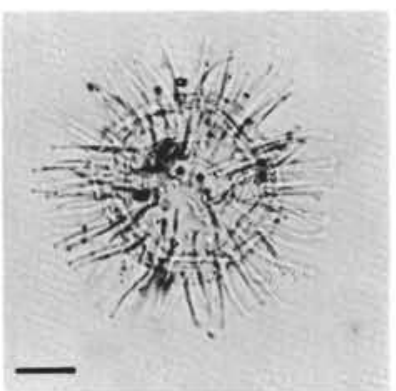

3

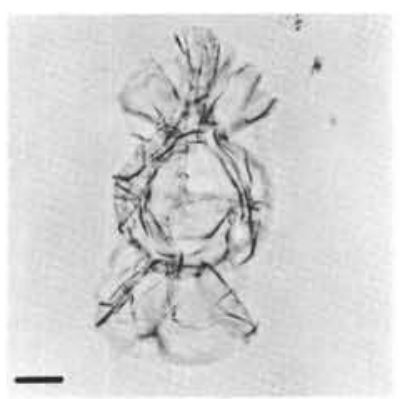

7

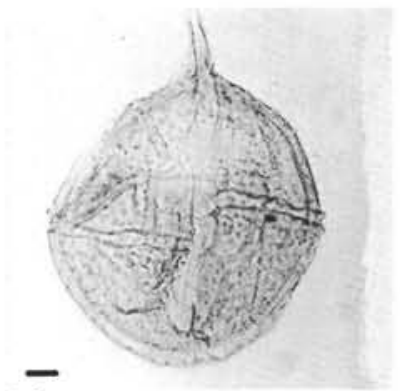

11

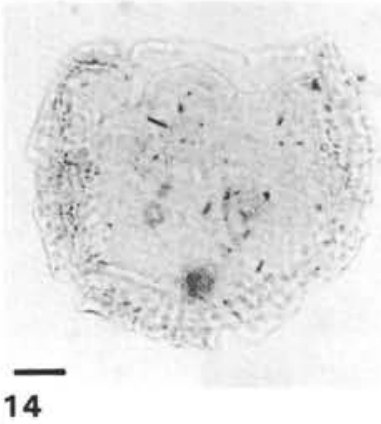

Plate 2. (Scale bar $=10 \mu \mathrm{m}$.) 1. Cassiculosphaeridia reticulata, breadth $65 \mu \mathrm{m}$, focused on reticulated surface ornamentation, slide I-6915: $41.9 /$ 112.2, Sample 547A-71-2, 83-85 cm. 2. Cerbia tabulata breadth $74 \mu \mathrm{m}$, specimen with low ornaments, (A) ventral focus, (B) dorsal focus; slide I-6937: 27.5/96.9; Sample 545-45-1, 59-62 cm. 3. Cleistosphaeridium clavulum, diameter $54 \mu \mathrm{m}$; slide III-6891: 37.5/105.7, Sample 547A-50-2, 130-133 cm. 4. Cleistosphaeridium multispinosum, diameter $77 \mu \mathrm{m}$, cingular view; slide II-6878: 47/106.2, Sample 547B-5-4, 147-150 cm. 5 . Codoniella campanula, length $96 \mu \mathrm{m}$, dorsal view, focused on precingular archeopyle, slide III-6893: 35.7/94.8, Sample 547A-51-4, 0-2 cm. 67. Codoniella psygma, (6) length $74 \mu \mathrm{m}$, dorsal focus, slide I-6937: 36.9/98.3, Sample 545-45-1, 59-62 cm, (7) length $84 \mu \mathrm{m}$, ventral focus, slide III-6930: $33.2 / 93,4$, Sample 545-40-6, 57-60 cm. 8. Cometodinium? whitei, diameter $76 \mu \mathrm{m}$, slide I-6952: 45.5/94, Sample 545-53-3, $90-94 \mathrm{~cm}$. 9. Coronifera oceanica, length $84 \mu \mathrm{m}$, cingular view, slide II-6895: 42.6/98, Sample 547A-53-1, 100-103 cm. 10. Coronifera tubulo$s a$, length $105 \mu \mathrm{m}$, dorsal precingular archeopyle showing to left top of figure, slide II-6938: 32.3/94.7, Sample 545-45-4, 40-43 cm. 11. Cribroperidinium orthoceras, length $120 \mu \mathrm{m}$, ventral focus, slide II-6946: 36.8/104, Sample 545-49-5, 49-52 cm. 12. Cyclonephelium brevispinatum, diameter $80 \mu \mathrm{m}$, ventral focus, slide III-6870: 31.4/111.1, Sample 547B-2-4, 116-120 cm. 13. Cyclonephelium chabaca, breadth $81 \mu \mathrm{m}$, dorso-ventral orientation, (A) cingular focus, (B) ventral focus; slide III-6919: 32.4/102.9, Sample 545-31-1, 130-133 cm. 14. Cyclonephelium compactum, breadth $78 \mu \mathrm{m}$, ventral focus, slide II-6878: 30.3/108.5, Sample 547B-5-4, 147-150 cm. 


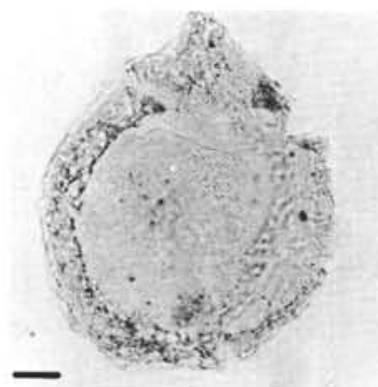

1

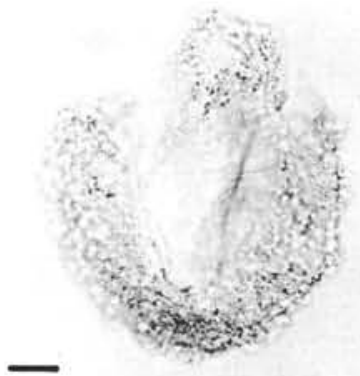

5

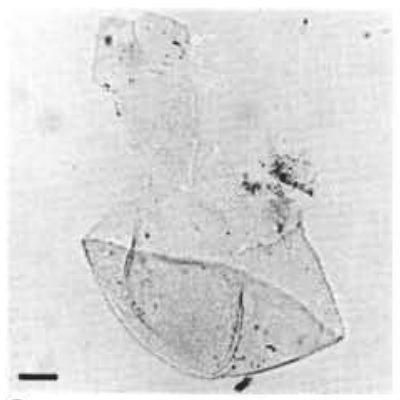

9

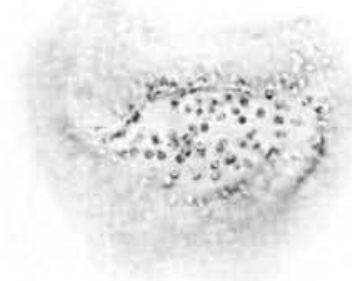

13A

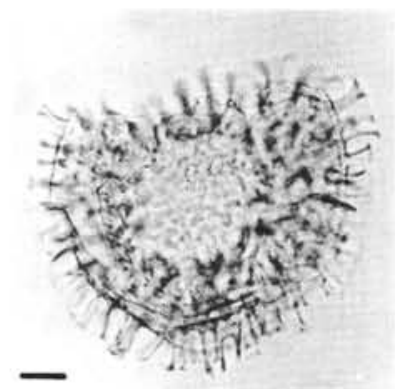

2

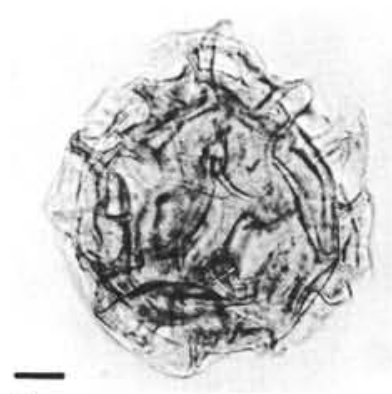

6

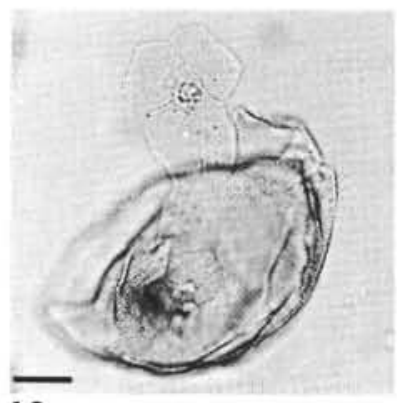

10

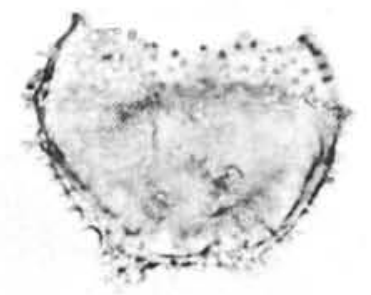

$13 B$

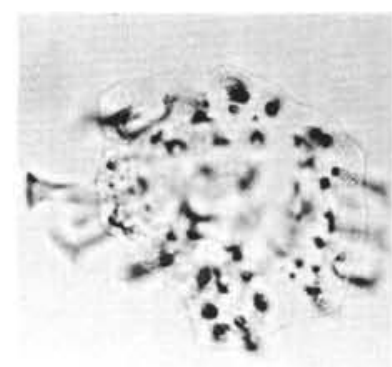

3

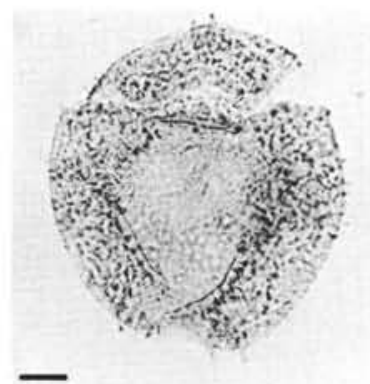

7

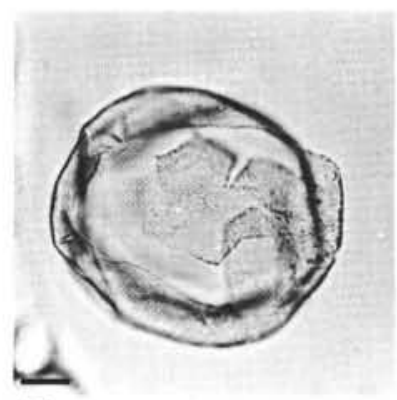

11

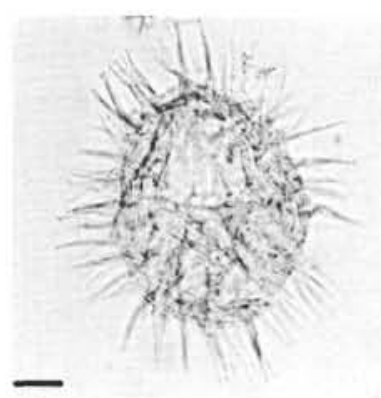

14

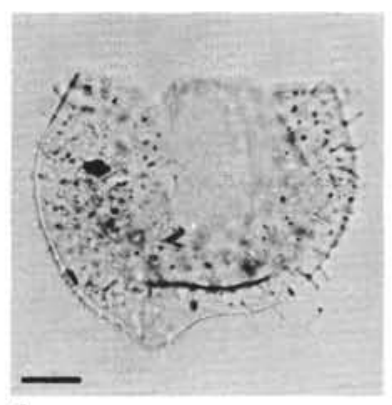

4

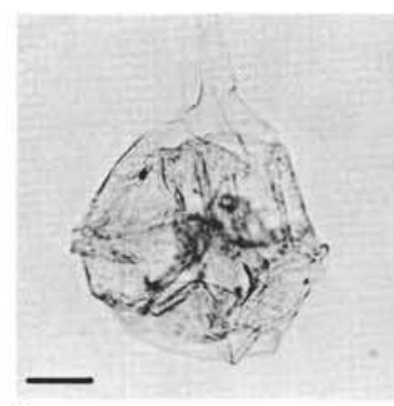

8

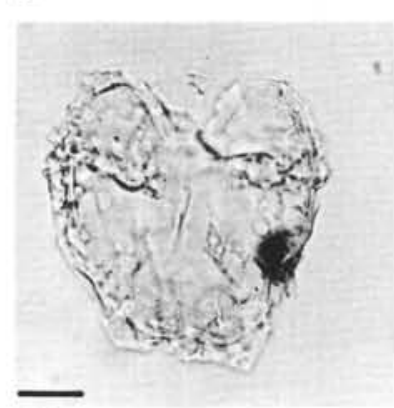

12

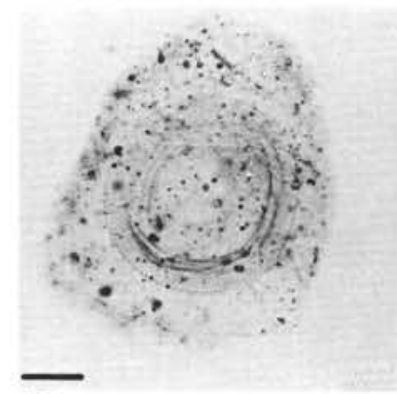

15

Plate 3. (Scale bar $=10 \mu \mathrm{m}$.) 1. Cyclonephelium compactum, length $90 \mu \mathrm{m}$, ventral focus, slide I-6878: $49.6 / 104.1$, Sample $547 \mathrm{~B}-5-4,147-150 \mathrm{~cm}$. 2. Cyclonephelium distinctum, (2) breadth $96 \mu \mathrm{m}$, cingular focus, slide II-6924: 42.3/101.1, Sample 545-36-1,44-47 cm. (3) breadth $78 \mu$ m, note operculum splits between the four apical paraplates, $1^{\prime}$ to the south, slide III-6919: 41.6/99.3, Sample 545-31-1, 130-133 cm. 4. Cyclonephelium hystrix, breadth $66 \mu \mathrm{m}$, dorsal focus; slide II-6938: 32.2/110.1, Sample 545-45-4, $40-43 \mathrm{~cm}$. 5. Cyclonephelium maugaad, breadth $70 \mu \mathrm{m}$, ventral focus, slide III-6945: 49.7/108.6, Sample 545-49-1, 34-37 cm. 6. Cyclonephelium cf. membraniphorum, diameter 72 $\mu \mathrm{m}$, cingular focus, slide II-6869: 27.6/108.1, Sample 547B-2-2, 0-2 cm. 7. Cyclonephelium paucimarginatum diameter $78 \mu \mathrm{m}$, cingular view, slide III-6905: 27/106, Sample 547A-61-2, 0-2 cm. 8. Dingodinium albertii, length $57 \mu \mathrm{m}$, slide I-6941: 37.8/93.5, Sample 545-47-2, 97-99 cm. 9-11. Dissiliodinium globulum, (a) length $102 \mu \mathrm{m}$, note apical paraplates, slide II-6938: 31.6/113.4, Sample 545-45-4, 40-43 cm; (10) breadth $66 \mu \mathrm{m}$, note four apical paraplates and preapical structures, slide I-6942: 40.7/111.7, Sample 545-47-6, 72-75 cm; (11) diameter 60 $\mu \mathrm{m}$, apical focus, slide I-6942: 30.7/108.2, Sample 545-47-6, 72-75 cm. 12. Ellipsoidictyum imperfectum length $54 \mu \mathrm{m}$, ventral focus, slide II-6942: 45/111,9, Sample 545-47-6, 72-75 cm. 13. Epelidosphaeridia spinosa, breadth $48 \mu \mathrm{m}$, (A) surface focus, (B) cingular focus, slide I-6919: $32.5 /$ 101.6; Sample 545-31-1, 130-133 cm. 14. Exochosphaeridium bifidum, length $90 \mu \mathrm{m}$, dorso-ventral orientation, operculum of precingular archeopyle somewhat distorted, cingular focus, slide II-6944: 47/104.1; Sample 545-48-6, 16-18 cm. 15. Eyrea nebulosa, diameter of central body $38 \mu \mathrm{m}$, note small apical bulge to the north, slide II-6897: 29/111.4, Sample 547A-55-2, 69-71 cm. 


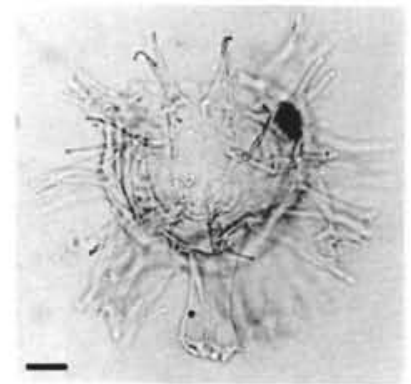

$1 \mathrm{~A}$

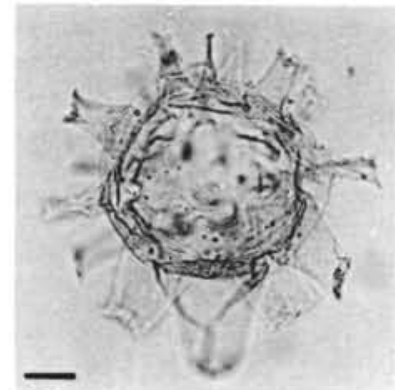

2B

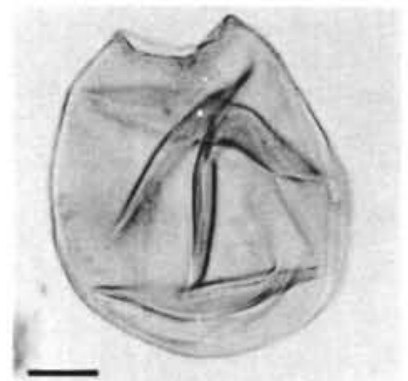

6

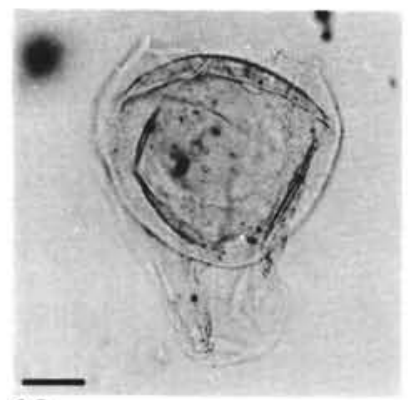

10

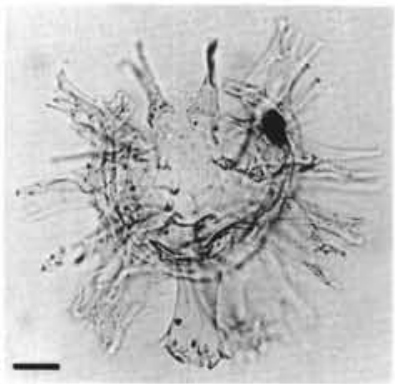

$1 \mathrm{~B}$

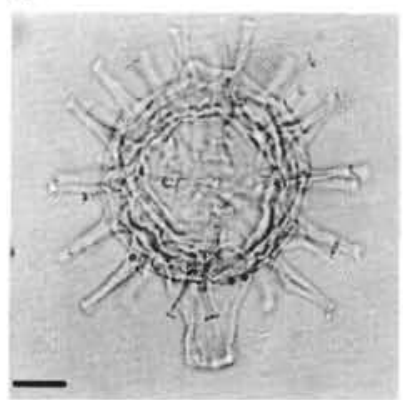

3

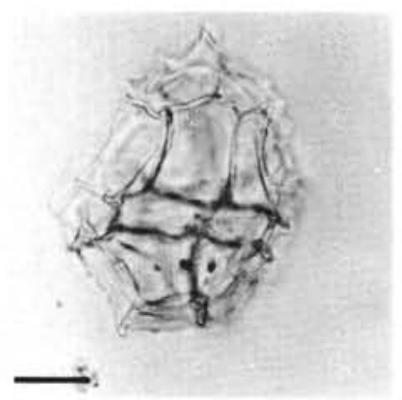

7

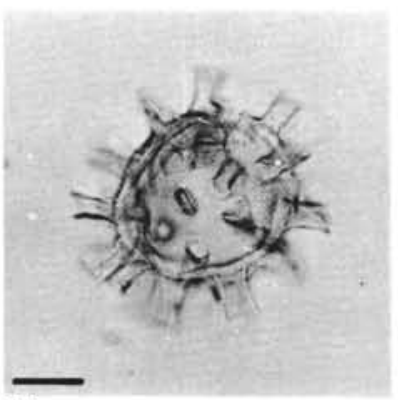

11

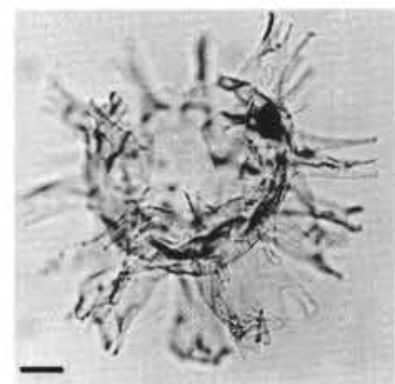

$1 \mathrm{C}$

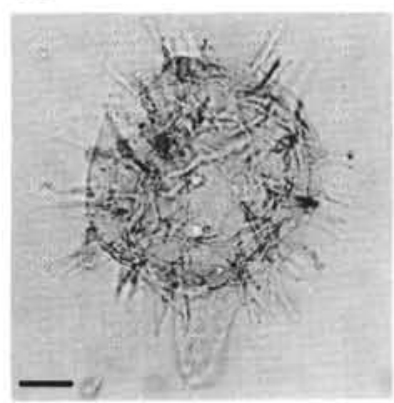

4

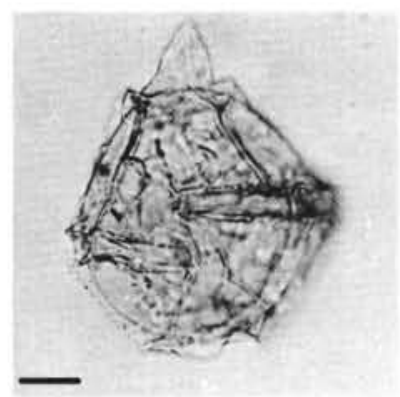

8

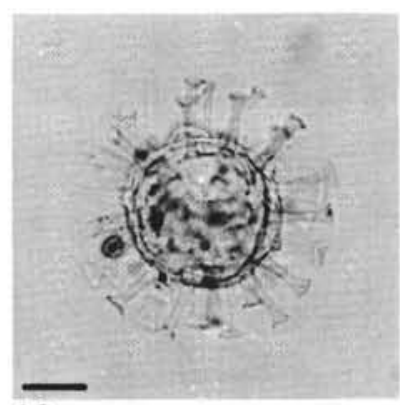

12

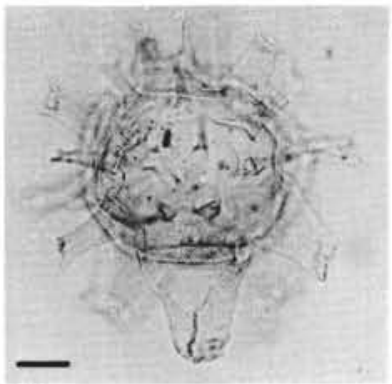

2A

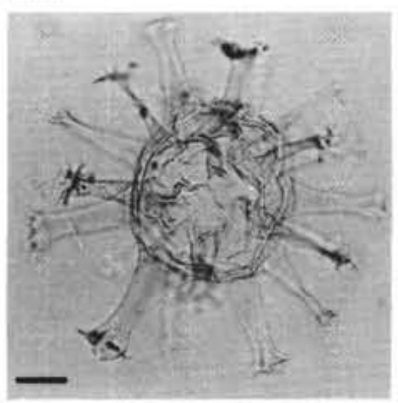

5

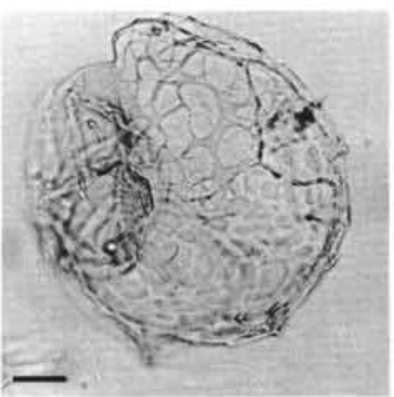

9

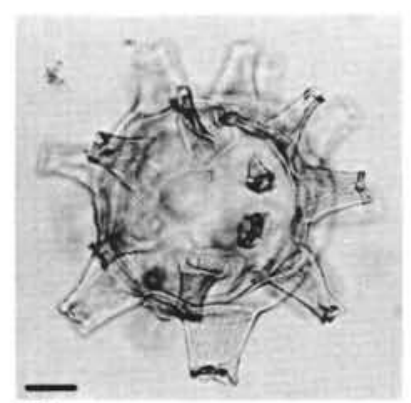

13

Plate 4. (Scale bar $=10 \mu \mathrm{m}$.) 1. Florentinia laciniata ssp. laciniata, length $95 \mu \mathrm{m}$, dorso-ventral orientation, (A) ventral focus, (B) cingular focus, (C) dorsal focus demonstrating the combination archeopyle, formed by loss of apical paraplates and the third precingular paraplate, slide II-6901: 32.4/94.8, Sample 547A-59-2, 0-2 cm. 2. Florentinia mantellii, length $78 \mu \mathrm{m}$, (A, B) two different foci, slide III-6896: 47.8/94.6, Sample 547A$54-1,60-62 \mathrm{~cm}$. 3. Florentinia radiculata, length $72 \mu \mathrm{m}$, oblique cingular view, slide II-6870: 46.2/106.4, Sample $547 \mathrm{~B}-2-4,116-120 \mathrm{~cm}$. 4. Florentinia resex, length $84 \mu \mathrm{m}$, oblique cingular view, slide II-6914: 44/103.7, Sample 547A-70-2, 90-93 cm. 5. Florentinia stellata, length 84 $\mu \mathrm{m}$, oblique cingular view, slide II-6906: 38.3/95.6, Sample 547A-61-4, 113-115 cm. 6. Fromea amphora, length $58 \mu \mathrm{m}$, slide II-6946: $44.1 /$ 98.6, Sample 545-49-5, 49-52 cm. 7. Gonyaulacysta cretacea, length $48 \mu \mathrm{m}$, oblique cingular view, dorsal to the left, slide III-6944: 32.9/99.6, Sample 545-48-6, 16-18 cm. 8. Gonyaulacysta helicoidea, length $58 \mu \mathrm{m}$, ventral focus, slide 6879: 26.1/111.3, Sample 547B-5-5, $100-103 \mathrm{~cm}$. 9. Hapsocysta dictyota, diameter $66 \mu \mathrm{m}$, oblique cingular focus, dorsal to the left, slide II-6909: 18.7/98.2, Sample 547A-63-4, 46-48 cm. 10. Hexagonifera cf. chlamydata, length $58 \mu \mathrm{m}$, oblique cingular view, slide I-6878: 42.8/104, Sample 547B-5-4, 147-150 cm. 11. Hystrichosphaeridium arundum, diameter $36 \mu \mathrm{m}$, oblique view, slide II-6872: 30.3/105.1, Sample 547B-5-1, 0-3 cm. 12. Hystrichosphaeridium cf. arundum, diameter $46 \mu \mathrm{m}$, note the long processes and compare with the typical $H$. arundum (Fig. 11), slide I-6874: 32.3/101.4, Sample 547B5-2, 47-50 cm. 13. Hystrichosphaeridium atlasense, diameter $75 \mu \mathrm{m}$, apical focus, slide III-6873: 45.9/109.8, Sample 547B-5-1, 102-105 cm. 


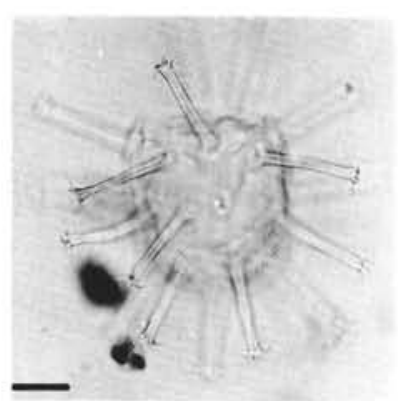

$1 \mathrm{~A}$

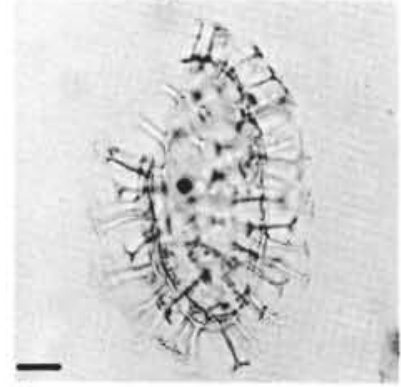

3

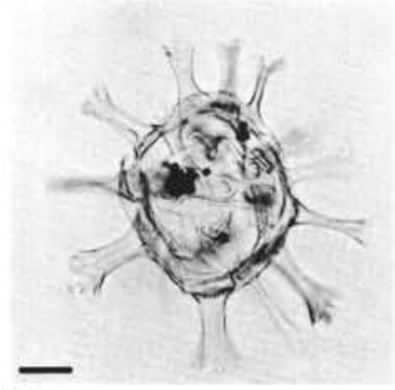

7

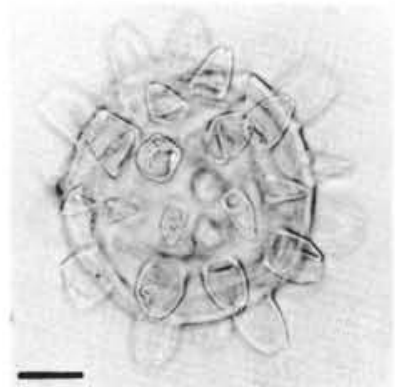

$9 B$

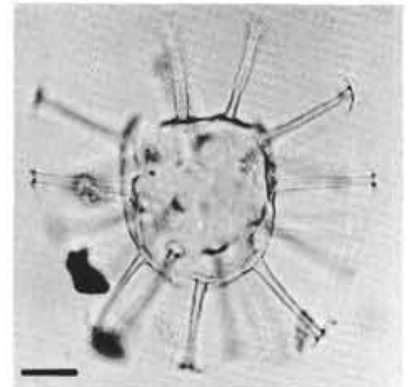

$1 B$

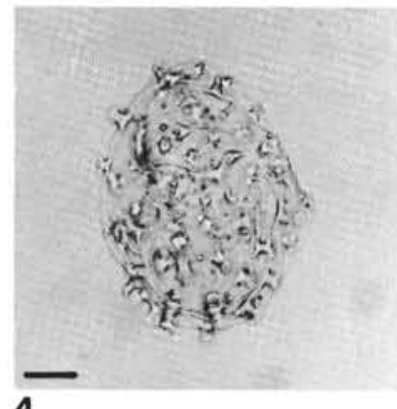

4

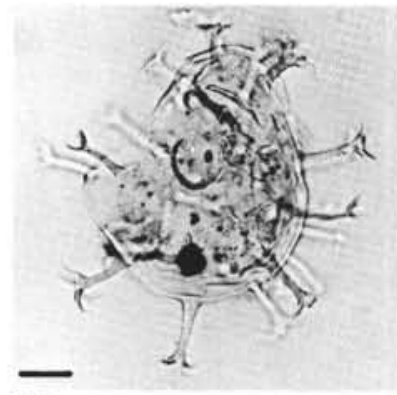

$8 A$

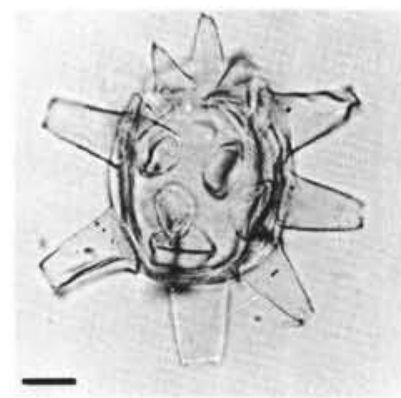

10

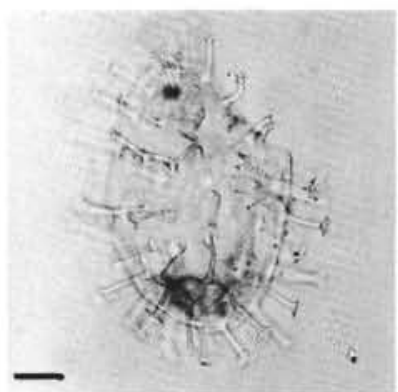

$2 A$

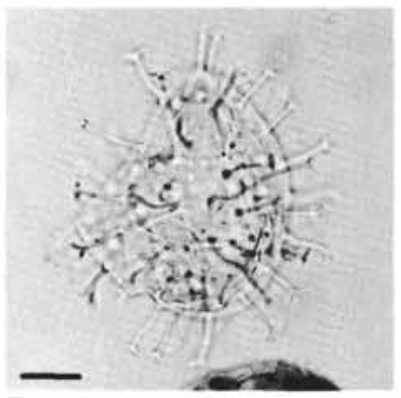

5

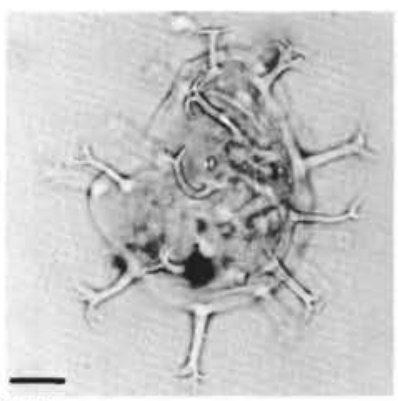

8B

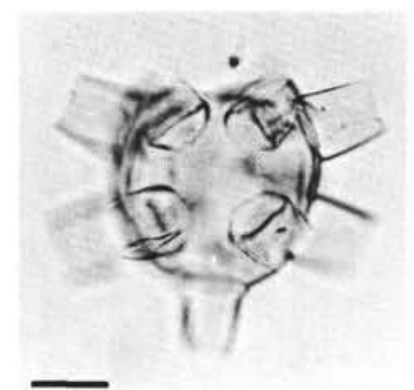

$11 \mathrm{~A}$

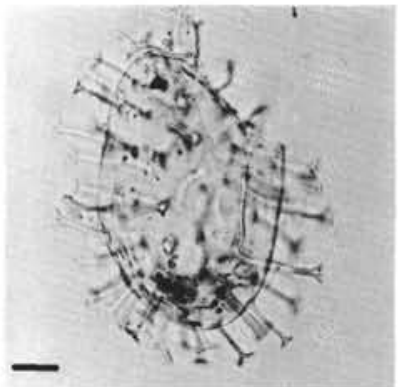

2B
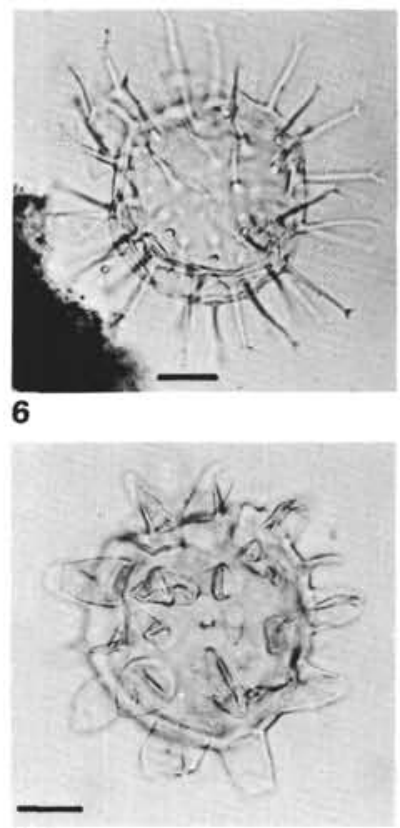

$9 A$

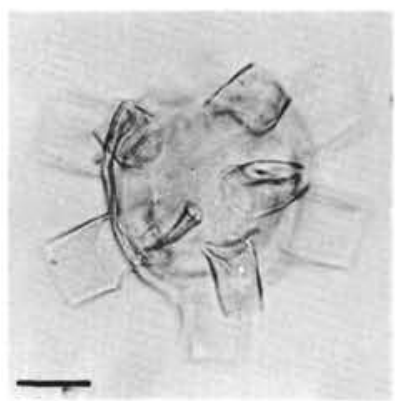

$11 \mathrm{~B}$

Plate 5. (Scale bar $=10 \mu \mathrm{m}$.) 1. Hystrichosphaeridium bowerbankii, length $72 \mu \mathrm{m}$, (A) ?dorsal focus, (B) oblique view, slide III-6919: 37.2/ 101.1, Sample 545-31-1, 130-133 cm. 2-4. Kiokansium corollum (2) length $88 \mu \mathrm{m}$, (A) oblique surface focus, (B) oblique cingular focus, archeopyle to the right, slide I-6922: 27.8/111.5, Sample 545-34-3, 44-46 cm; (3) length $86 \mu \mathrm{m}$, oblique cingular focus, archeopyle to the left, note extremely elongated form, slide II-6915: 43.8/105.7, Sample 547A-71-2, 83-85 cm; (4) length $60 \mu \mathrm{m}$, note the extreme reduction of appendages, slide II-6895: 43.5/99.4, Sample 547A-53-1 100-103 cm. 5. Kiokansium hydra, length $63 \mu \mathrm{m}$, oblique cingular view, archeopyle to the left, slide I-6946: $34.4 / 107.5$, Sample $545-49-5,49-52 \mathrm{~cm}$. 6. Kiokansium polypes, diameter $68 \mu \mathrm{m}$, oblique cingular focus, slide I-6941: $45.6 / 105.2$, Sample 545-47-2, 97-99 cm. 7. Kleithriasphaeridium eoinodes, length $75 \mu \mathrm{m}$, oblique cingular focus, archeopyle to the left, slide I-6939: 41.9/ 98.3, Sample 545-46-2, 63-66 cm. 8. Kleithriasphaeridium? sarmentum, length $74 \mu \mathrm{m}$, archeopyle to the left, (A) oblique cingular focus, (B) oblique surface focus, slide I-6936: 31.4/97.1, Sample 545-44-2, 78-82 cm. 9. Litosphaeridium conispinum, diameter $60 \mu \mathrm{m}$, (A) ventral focus, (B) dorsal focus, slide II-6880: 49.8/109.3, Sample 547B-5-6, 50-53 cm. 10-11. Litosphaeridium siphoniphorum, (10) length 68 $\mu \mathrm{m}$, ventral focus, slide II-6923: 48.9/96.7, Sample 545-34-3, 44-46 cm; (11) diameter $50 \mu \mathrm{m}$; (A) dorsal focus; B, ventral focus), slide III-6893: 33.7/111.3, Sample 547A-51-4, 0-2 cm. 


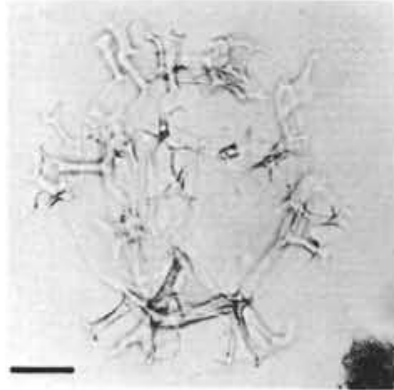

1

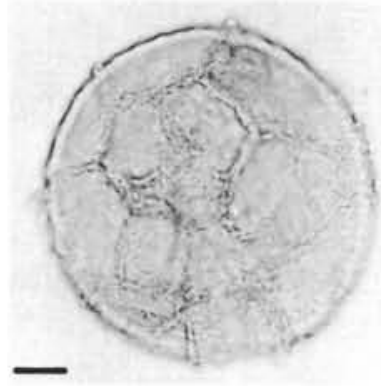

4A

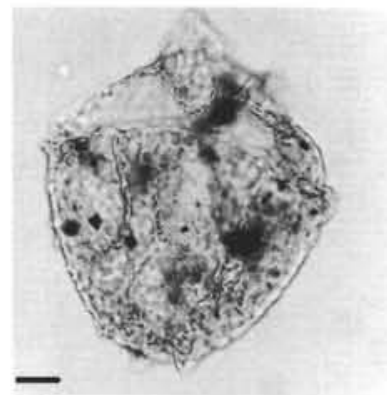

7A

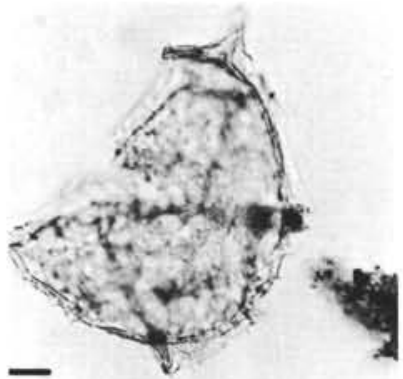

8B

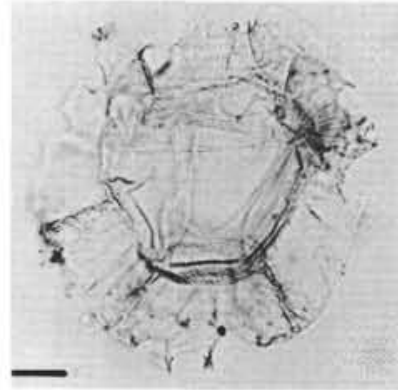

2

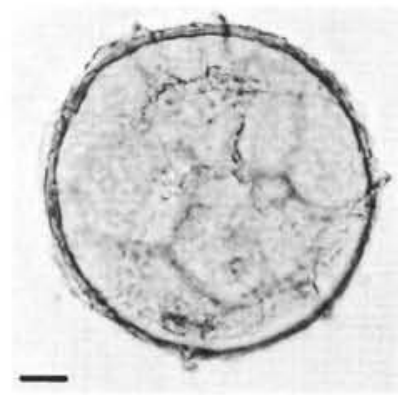

$4 B$

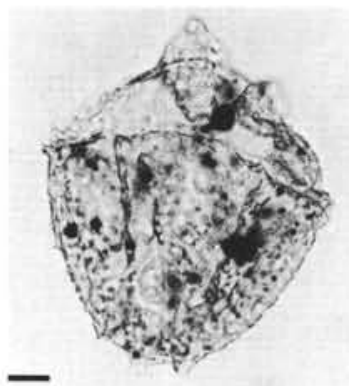

7B

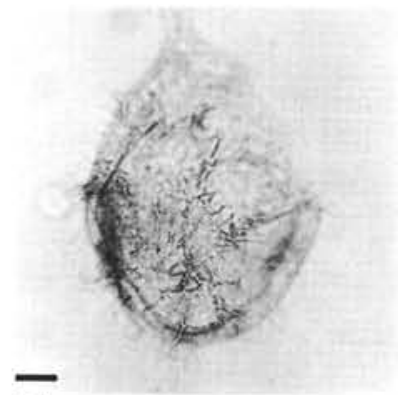

9A

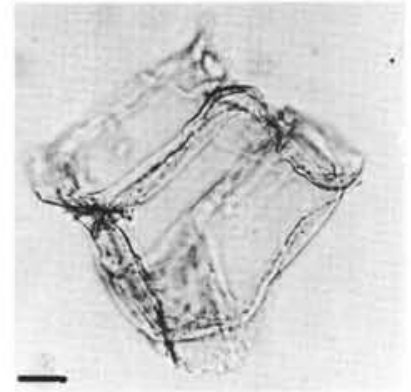

3A

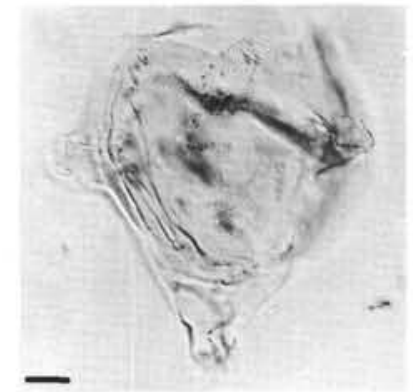

5
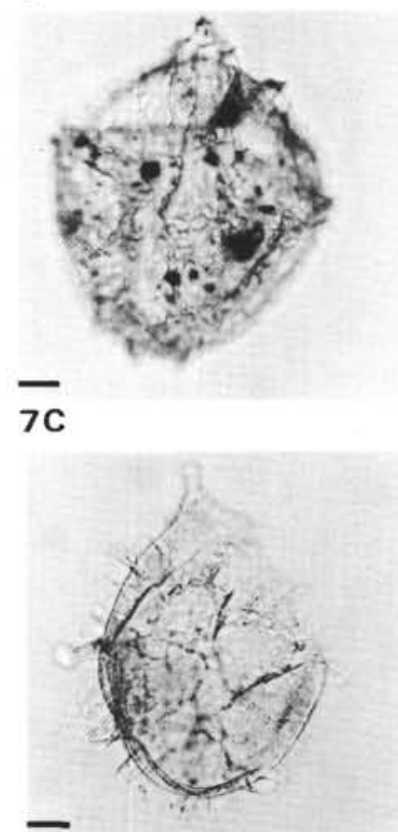

$9 \mathrm{~B}$

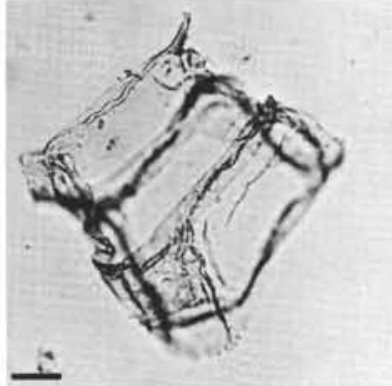

3B

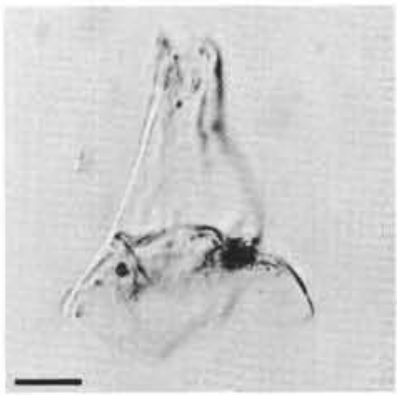

6

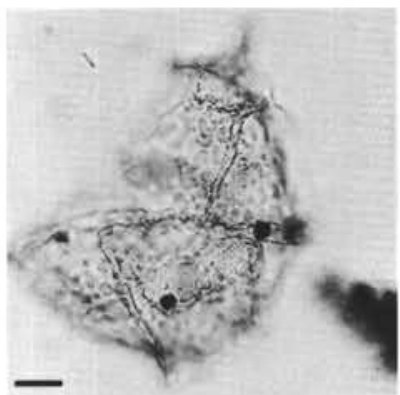

8A

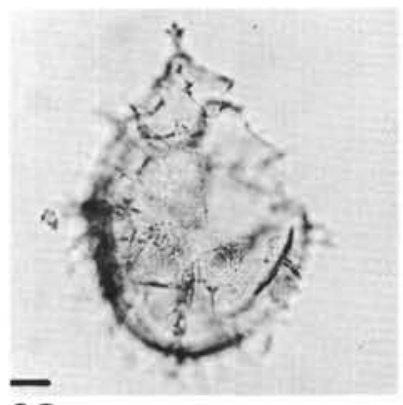

9C

Plate 6. (Scale bar $=10 \mu \mathrm{m}$.) 1. Maghrebinia chleuh, length $72 \mu \mathrm{m}$, oblique cingular view, slide II-6901: 51.3/106.3, Sample 547A-59-2, 0-2 cm. 2 . Maghrebinia perforata ssp. mirabilis n.ssp., length $78 \mu \mathrm{m}$, slide III-6919: 30.6/108.7, Sample 545-31-1, 130-133 cm; 3. Maghrebinia perforata ssp. perforata, length $78 \mu \mathrm{m}$, (A, dorsal focus; B, ventral focus), slide III-6889: 35.7/97.5, Sample 547A-48-2, 75-77 cm. 4. Meiourogonyaulax cf. bulloidea, diameter $72 \mu \mathrm{m}$, (A) apical focus, (B) antapical focus, slide IV-6938: 41.4/101, Sample 545-45-4, 40-43 cm. 5-6. Muderongia perforata, (5) length $84 \mu \mathrm{m}$, dorsal focus, slide III-6936: 31.6/111.2, Sample 545-44-2, 78-82 cm; (6) breadth of operculum, $40 \mu \mathrm{m}$, slide III-6947: 39/106.5, Sample 545-50-1, 147-150 cm. 7-8. Occisucysta hinzii n.sp., length $96 \mu \mathrm{m}$, holotype (A, dorsal focus; B, cingular focus, C, ventral focus); slide IV-6938: 41.4/101, Sample 545-45-4, 40-43 cm; (8) length $102 \mu \mathrm{m}$, (A oblique view, note surface structure; B, oblique cingular focus, note apical horn in somewhat excentrical positions) slide I-6937: 48.4/105.6, Sample 545-45-1, 59-62 cm. 9. Occisucysta mazaganensis n.sp., length $96 \mu \mathrm{m}$, (A) ventral focus, (B) cingular focus, (C) oblique dorsal focus, slide I-6879: 31.2/106,8, Sample 547B-5-5, $100-103 \mathrm{~cm}$. 


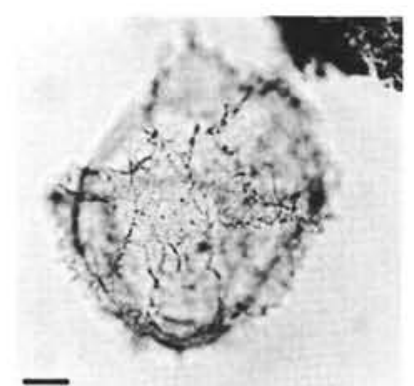

$1 \mathrm{~A}$

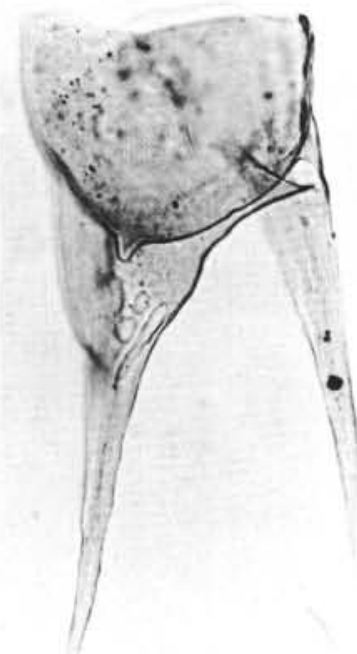

3

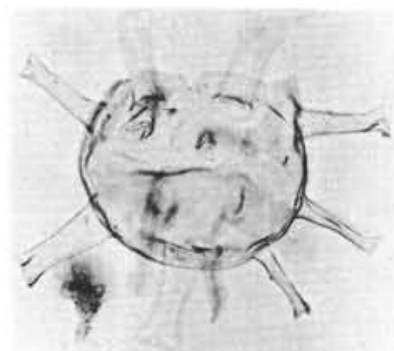

10

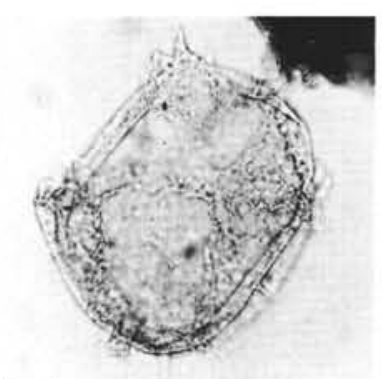

$1 \mathrm{~B}$

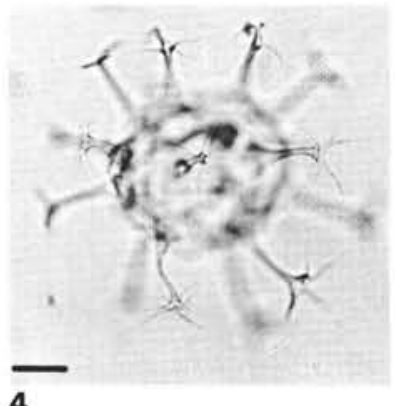

4

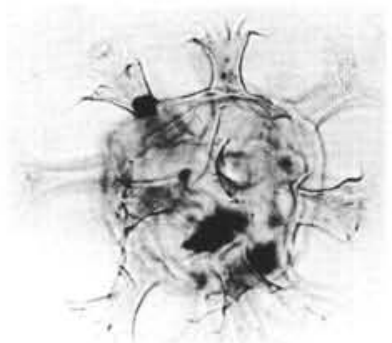

7

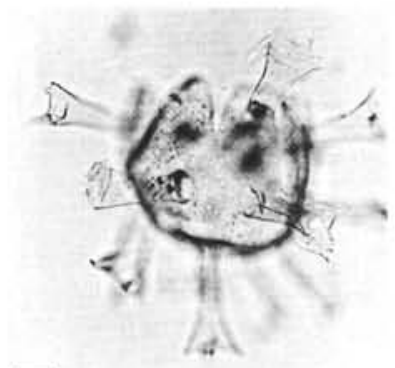

11

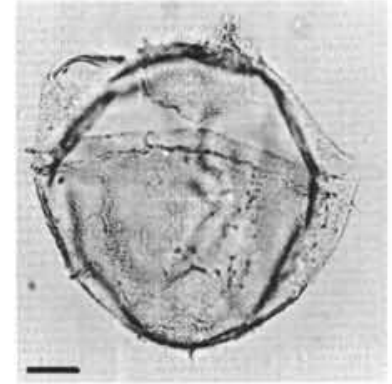

$2 A$

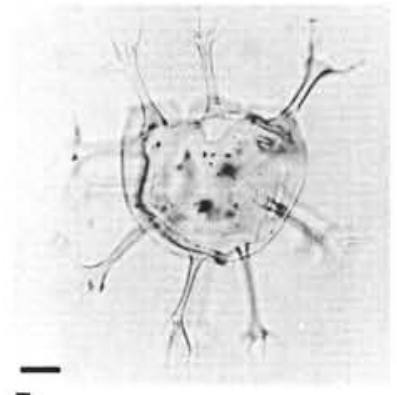

5

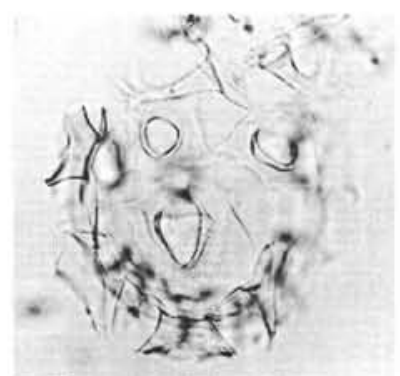

8

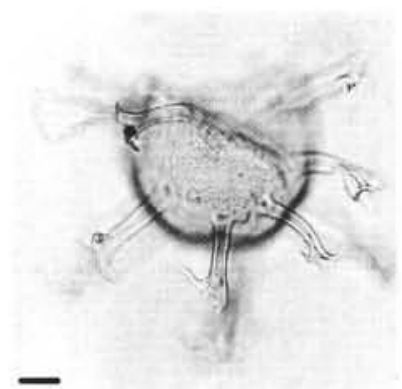

12

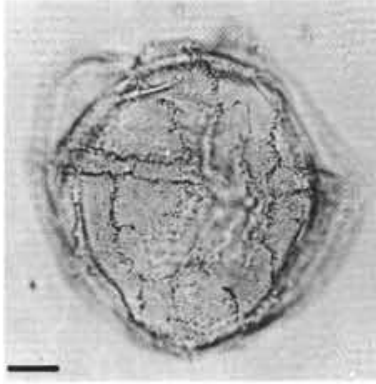

2B

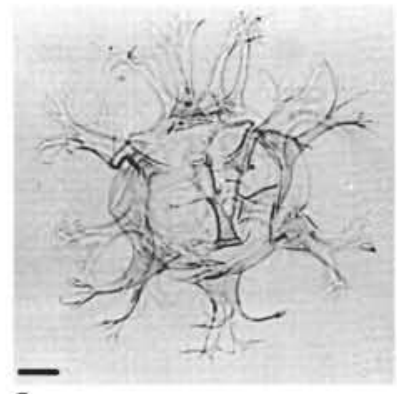

6

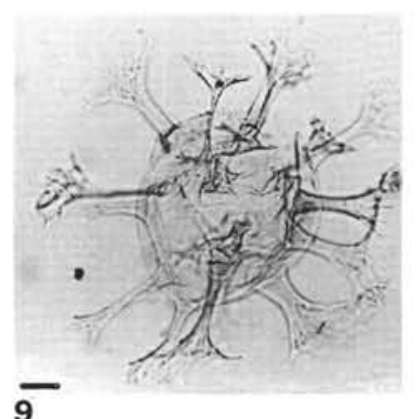

9

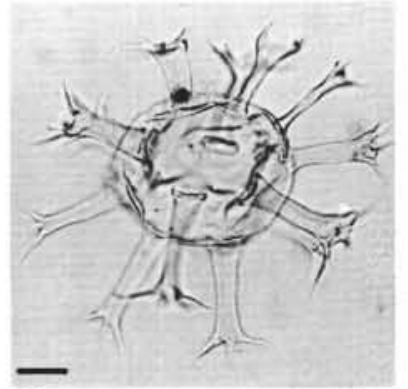

13

Plate 7. (Scale bar $=10 \mu \mathrm{m}$.) 1. Occisucysta mazaganensis n.sp., length $84 \mu \mathrm{m}$, holotype, (A) ventral focus, (B) dorsal focus, slide III-6879: 40.7/ 107.7, Sample 547B-5-5, 100-103 cm. 2. Occisucysta sousensis, length $72 \mu \mathrm{m}$, (A) dorsal focus, (B) ventral focus, slide II-6930: 43.1/99.8, Sample 545-40-6, 57-60 cm. 3. Odontochitina operculata, length $265 \mu \mathrm{m}$, dorsal focus, slide II-6905: 36.6/110, Sample 547A-61-2, 0-2 cm. 4 . Oligosphaeridium asterigerum, diameter $72 \mu \mathrm{m}$, focused on distal termination of processes, slide III-6873: 41/110.8, Sample 547B-5-1, $102-105 \mathrm{~cm}$. 5. Oligosphaeridium complex, diameter $90 \mu \mathrm{m}$, ventral focus, slide I-6954: $41.3 / 107.3$, Sample $545-55-1,60-62 \mathrm{~cm}$. 6. Oligosphaeridium dividuum, diameter $108 \mu \mathrm{m}$, slide II-6897: 35.7/112.5, Sample 547A-55-2, 69-71 cm.7. Oligosphaeridium cf. albertense, slide III6939: 36/102.7, Sample 545-46-2, 63-66 cm. 8. Oligosphaeridium poculum, diameter $70 \mu \mathrm{m}$, dorsal focus, slide III-6921: 41.1/110.7, Sample 545-33-1, 90-94 cm. 9. Oligosphaeridium pulcherrimum, diameter $108 \mu \mathrm{m}$, slide II-6909: 24.4/100.8, Sample 547A-63-4, 46-48 cm. 10. Oligosphaeridium totum ssp. minor, diameter $102 \mu \mathrm{m}$, cingular focus, slide II-6948: 32.5/105.2, Sample 545-50-6, 56-58 cm; 11-13. Oligosphaeridium verrucosum, (11) diameter $114 \mu \mathrm{m}$, note coarse granulae, slide I-6945: 30.2/105, Sample 545-49-1, 34-37 cm; (12) diameter $114 \mu \mathrm{m}$, note dense granulation, slide III-6950: 42/100.2, Sample 545-51-6, 66-69 cm; (13) diameter $86 \mu \mathrm{m}$, note the smooth surface, slide I-6944: $39 / 107.8$, Sample 545-48-6, 16-18 cm. 


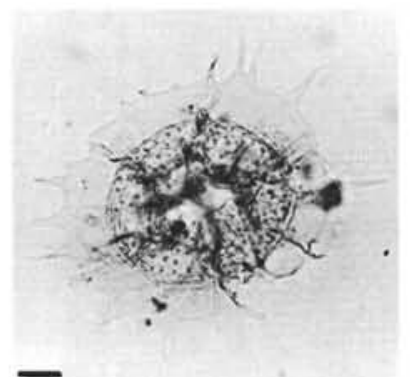

1

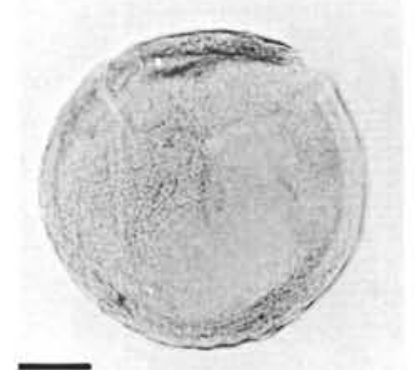

5

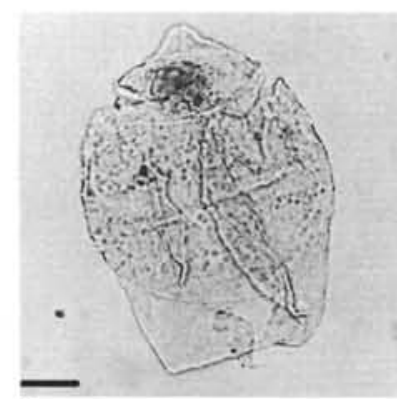

9

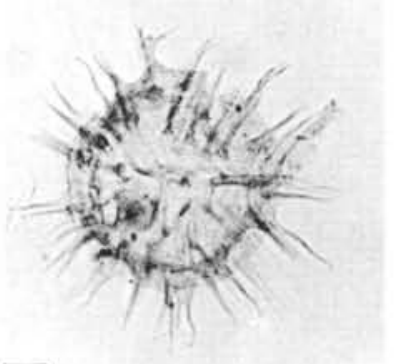

$13 \mathrm{~A}$

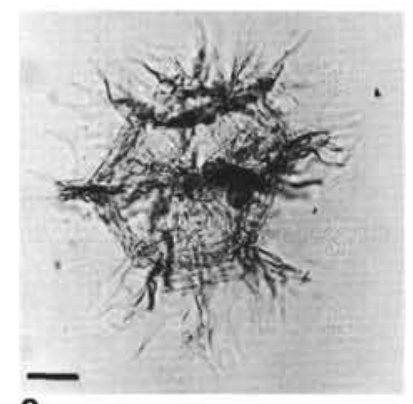

2

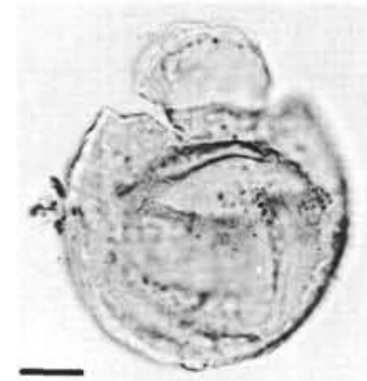

6

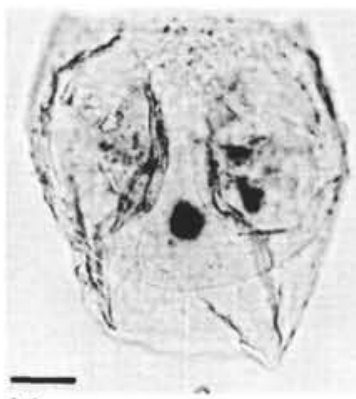

10

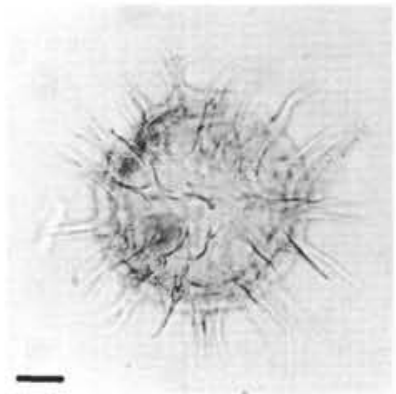

$13 B$

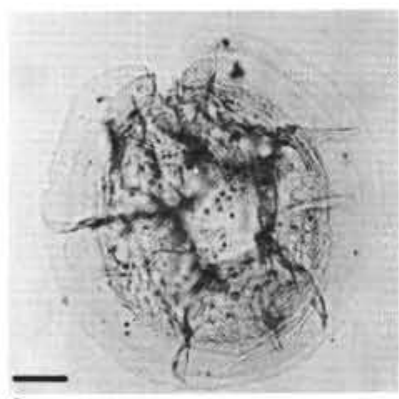

3
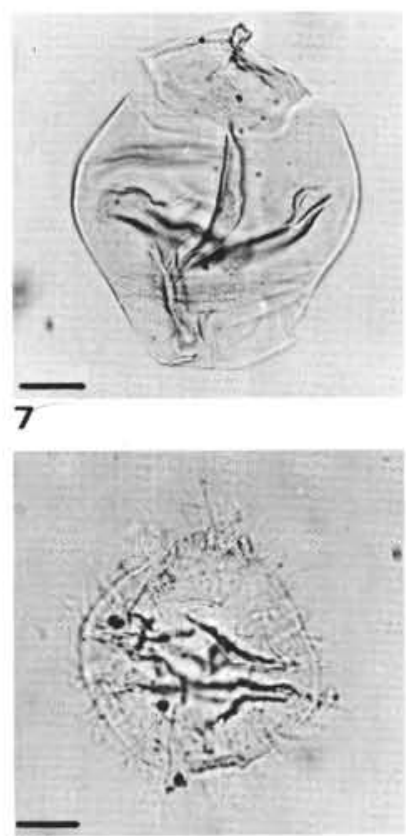

11

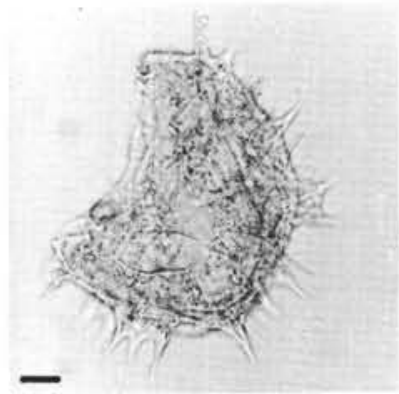

14

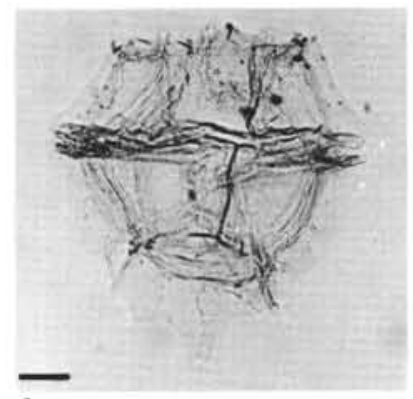

4
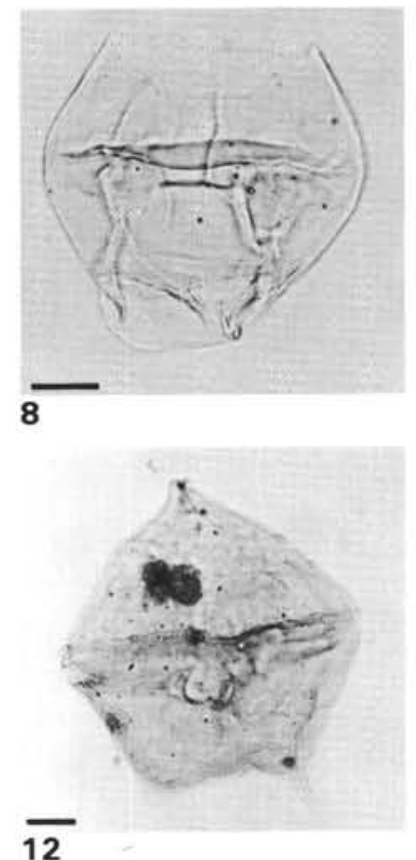

12

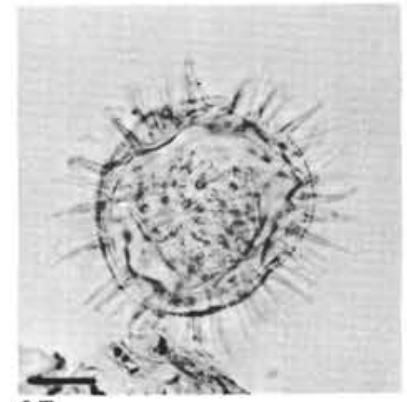

15

Plate 8. (Scale bar $=10 \mu \mathrm{m}$.) 1-2. Oodnadattia alata, (1) diameter $96 \mu \mathrm{m}$, apical view, slide I-6919: 38.2/109, Sample 545-31-1, 130-133 cm; (2) length $84 \mu \mathrm{m}$, dorsal focus, slide I-6919: 29.6/103.4, Sample 545-31-1, 130-133 cm. 3-4. Oodnadattia tuberculata, (3) diameter $72 \mu \mathrm{m}$, antapical view, slide I-6893: 36/106.4, Sample 547A-51-4, 0-2 cm; (4) diameter $78 \mu \mathrm{m}$, dorsal focus, slide II-6909: 23,4/106.4, Sample 547A-59-4, $148-150 \mathrm{~cm}$. 5. Ovoidinium diversum?, diameter $48 \mu \mathrm{m}$, cingular focus, slide III-6869: $43.5 / 101.5$, Sample $547 \mathrm{~B}-2-2,0-2 \mathrm{~cm}$. 6. Ovoidinium implanum?, diameter $48 \mu \mathrm{m}$, slide I-6896: 45.9/109.9, Sample 547A-54-1, 60-62 cm. 7. Ovoidinium scabrosum, (7) breadth $48 \mu \mathrm{m}$, dorsal focus, slide III-6896: $38.8 / 102$, Sample 547-54-1, 60-62 cm. (8) breadth $48 \mu \mathrm{m}$, dorsal focus, slide III-6897: 25.6/104.4, Sample 547A-55-2, 69-71 cm. 9-10. Ovoidinium verrucosum, (9) length $66 \mu \mathrm{m}$, slide III-6895: 30.4/97.8, sample 547A-53-1, 100-103 cm; (10) breadth $51 \mu \mathrm{m}$, slide I-6922: $28.5 / 99$, Sample 545-34-3, 44-46 cm. 11. Palaeohystrichophora infusorioides, length $60 \mu \mathrm{m}$, slide I-6926: 37/108.3, Sample 545-38-1, 120-123 cm. 12. Palaeoperidinium cf. cretaceum, length $78 \mu \mathrm{m}$, slide II-6897: 30.3/100.7, Sample 547A-55-2, 69-71 cm. 13. Pervosphaeridium pseudohystrichodinium, diameter $85 \mu \mathrm{m}$, oblique orientation, (A) cingular focus, (B) surface focus, archeopyle to the right, operculum in situ, slide I-6912: 48.9/96.9, sample 547A-68-1, 101-105 cm. 14. Pervosphaeridium truncatum, length $97 \mu \mathrm{m}$, oblique cingular focus, archeopyle to the left, slide II-6919: 49.8/105.5, Sample 545-31-1, 130-133 cm. 15. Polysphaeridium sp. sensu Below (1982b), diameter $54 \mu \mathrm{m}$, slide II-6937: $45.4 / 101.3$, Sample 545-45-1, 59-62 cm. 

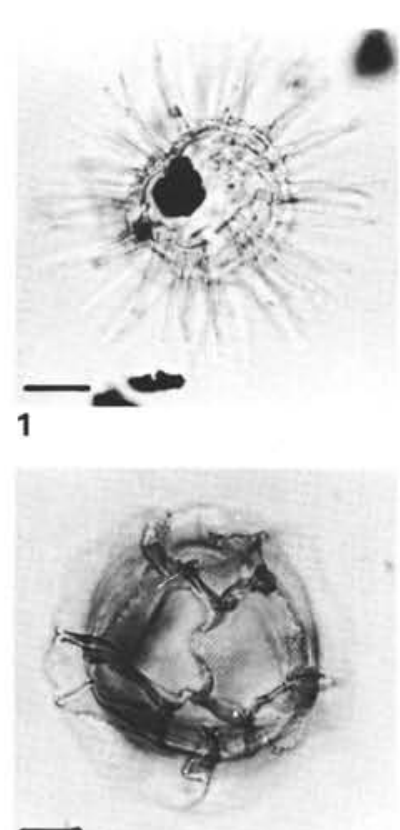

$5 A$

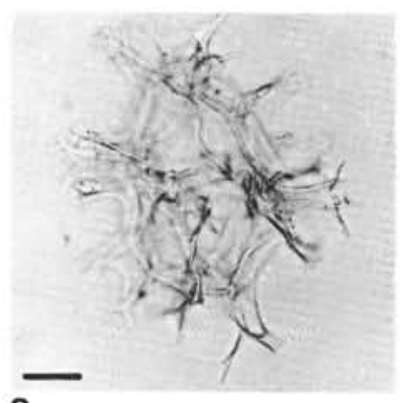

8

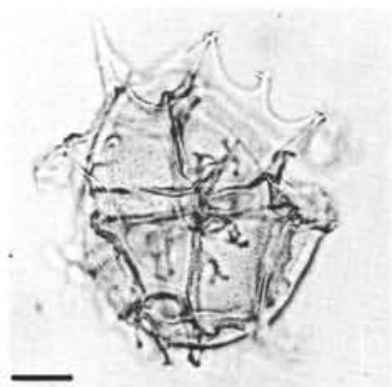

12

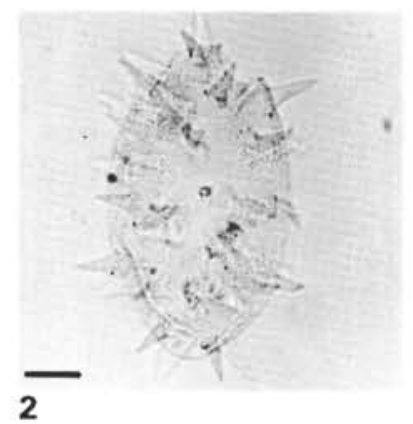

2

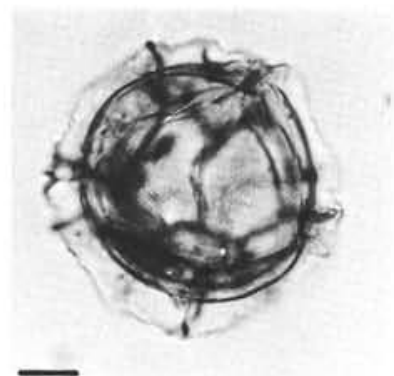

5B

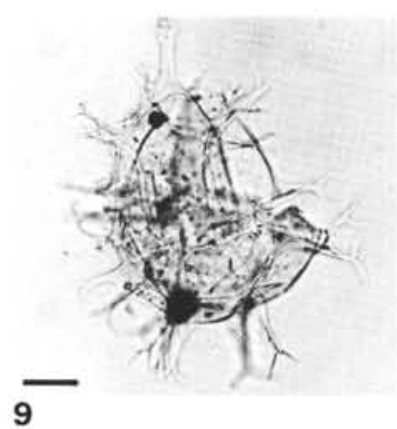

9

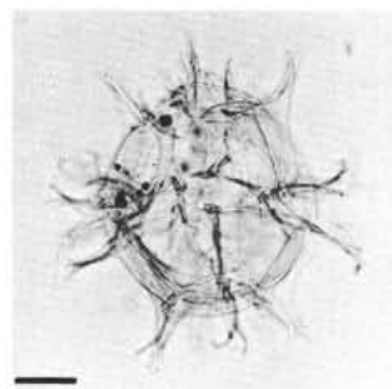

13

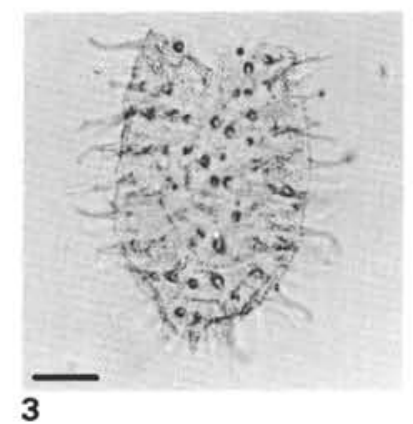

3

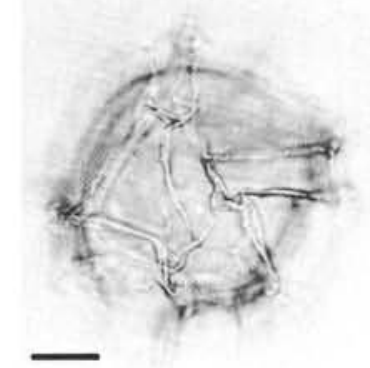

6

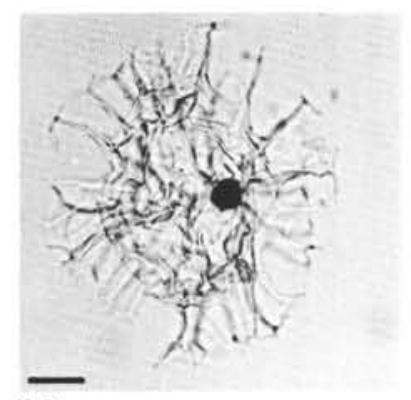

10

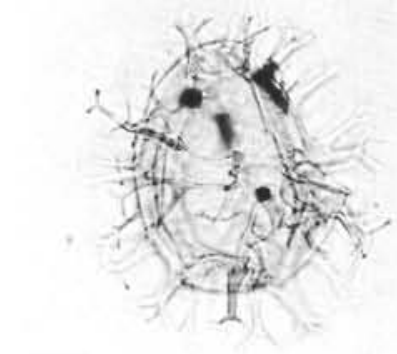

14
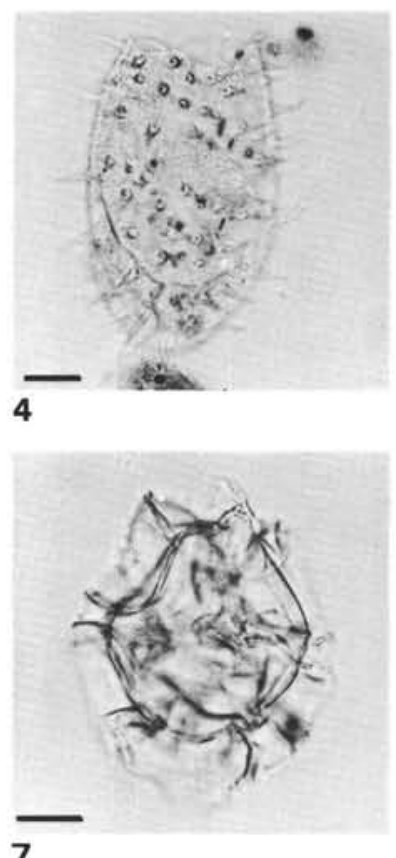

7

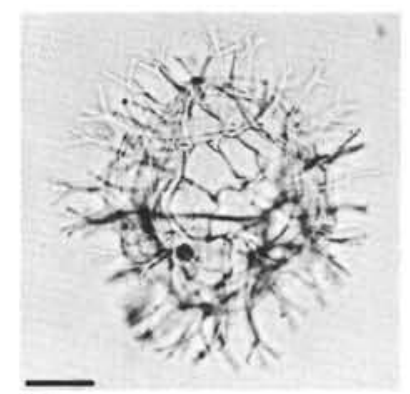

11

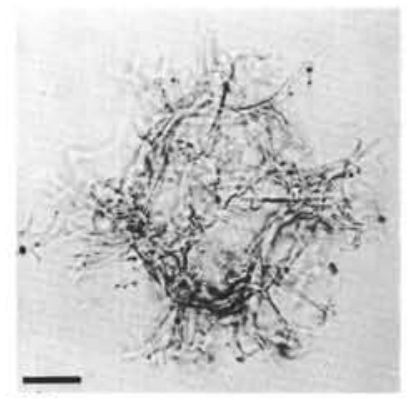

15

Plate 9. (Scale bar $=10 \mu \mathrm{m}$.) 1. Polysphaeridium warrenii, diameter $56 \mu \mathrm{m}$, slide I-6937: 34/109.7, Sample 545-45-1, 59-62 $\mathrm{cm}$. 2 . Prolixosphaeridium conulum, length $74 \mu \mathrm{m}$, slide II-6897: 46/97.6, Sample 547A-55-2, 69-71 cm. 3. Prolixosphaeridium parvispinum. ssp. deirense length $60 \mu \mathrm{m}$, slide III-6939: 38.2/92.4, Sample 545-46-2, 63-66 cm. 4. Prolixosphaeridium parvispinum ssp. parvispinum ssp. length $71 \mu \mathrm{m}$, slide II-6936: 49.5/103.2, Sample 545-44-2, 78-82 cm. 5. Pterodinium cingulatum ssp. cingulatum, diameter $54 \mu \mathrm{m}$, (A) dorsal focus, (B) cingular focus, slide III-6914: 33.6/102.4, Sample 547A-70-2, 90-93 cm. 6. Pterodinium cornutum, (6) diameter $48 \mu \mathrm{m}$, ventral focus, slide I-6939: 38.1/107.2, Sample 545-46-2, 63-66 cm; (7) length $58 \mu \mathrm{m}$, cingular focus, slide III-6948: 33.4/101.8, Sample 545-50-6, 56-58 cm. 8. Spiniferites ancoriferus ssp. ancoriferus, length $78 \mu \mathrm{m}$, slide II-6923: 31.7/99, Sample 545-35-1, 97-99 cm. 9. Spiniferites cornutus, length $90 \mu \mathrm{m}$, oblique cingular focus, archeopyle to the right, slide II-6937: $24.4 / 108$, Sample $545-45-1,59-62 \mathrm{~cm}$. 10. Spiniferites hyperacanthus, length $65 \mu \mathrm{m}$, slide I-6950: 46.4/102.2, Sample 545-51-6, 66-69 cm. 11. Spiniferites lenzii, length $56 \mu \mathrm{m}$, slide II-6901: 43/97.2, Sample 547A59-2, 0-2 cm. 12. Spiniferites multibrevis ssp. ghiran, length $60 \mu \mathrm{m}$, oblique cingular focus, archeopyle to the right, slide I-6944: 44.3/101.6, Sample 545-48-6, 16-18 cm. 13. Spiniferites multibrevis, ssp. multibrevis, length $63 \mu \mathrm{m}$, slide III-6889: 44/96, Sample 547A-48-2, 75-77 cm. 14. Spiniferites multibrevis, ssp. seghiris, length $66 \mu \mathrm{m}$, oblique cingular view, archeopyle to the right, slide I-6905: 35.5/95.5, Sample 547A-61-2, 0-2 cm. 15. Spiniferites cf. wetzelii, length $68 \mu \mathrm{m}$, ventral focus, slide I-6872: 27.3/95.8, Sample 547B-5-1, 0-3 cm. 

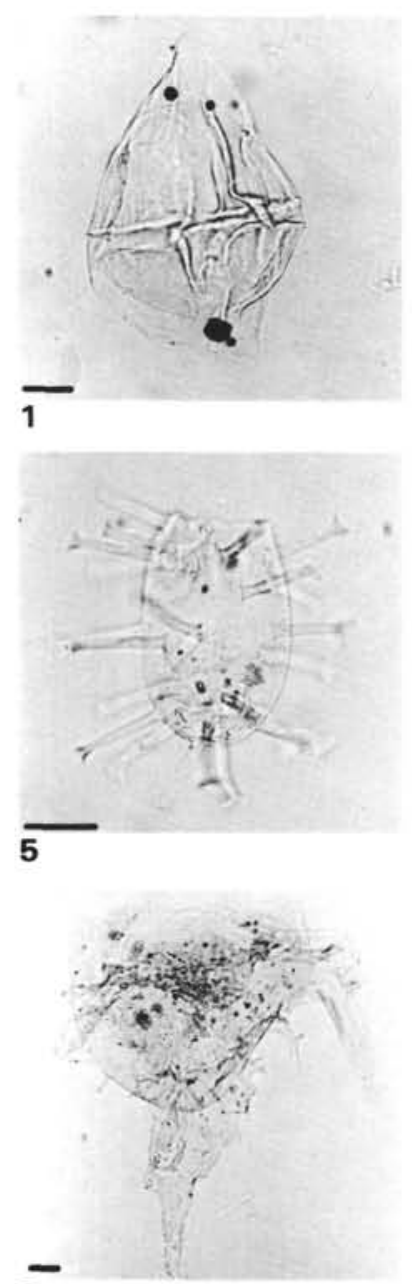

9

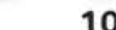

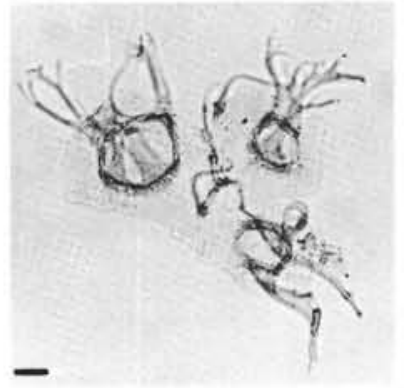

3
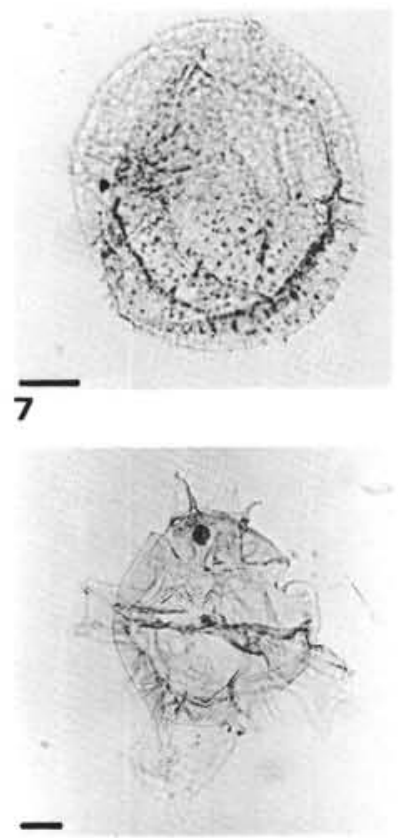

11

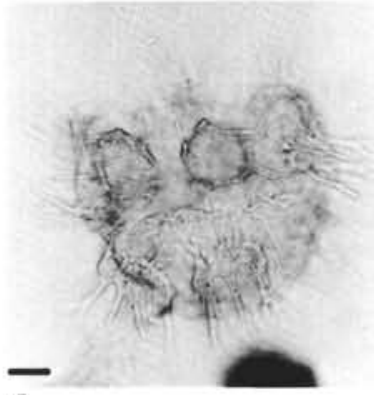

4
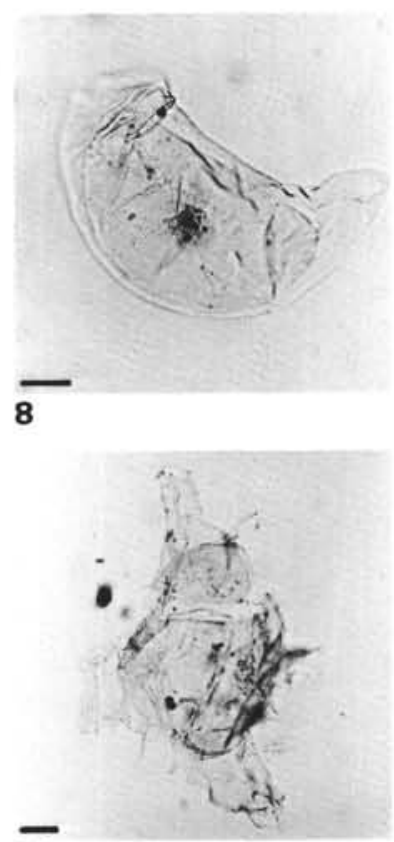

12 Systematophora? sp. MAZ, diameter $72 \mu \mathrm{m}$, note fibrous processes, slide I-6946: 48.3/113.2, Sample 545-49-5, 49-52 cm. 3-4. Systematophora cretacea (3) max. breadth of operculum $84 \mu \mathrm{m}$, operculum with three apical paraplates attached, one paraplate lost, slide III-6938: 32.7/98, Sample 545-45-4, 40-43 cm; (4) breadth $102 \mu \mathrm{m}$, dorsal focus, slide I-6938: 33.1/110.3, Sample 545-45-4, 40-43 cm. 5. Tanyosphaeridium boletum, length $48 \mu \mathrm{m}$, slide II-6922: 31.8/108, Sample 545-34-3, 44-46 cm. 6. Trabeculodinium quinquetrum, length $60 \mu \mathrm{m}$, slide I-6917: $32.8 / 97.5$, Sample 547A-72-4, 147-150 cm. 7. Trichodinium castanea, diameter $60 \mu \mathrm{m}$, slide III-6915: 37.2/100.1, Sample 547A-71-2, 83-85 cm. 8. Wallodinium luna, length $70 \mu \mathrm{m}$, slide I-6937: 26.1/101, Sample 545-45-1, 59-62 cm. 9-12. Xenascus ceratioides, length $114 \mu \mathrm{m}$, slide II-6905: 50/111.8, Sample 547A-63-4, 46-48 cm; (10) length $74 \mu \mathrm{m}$, slide II-6882: 46.8/102.3, Sample 547A-21-4, 110-113 cm; (11) length $96 \mu \mathrm{m}$, slide II-6904: 33.7/100, Sample 547A-60-4, 138-140 cm; (12) length $110 \mu \mathrm{m}$, slide II-6903: 36.5/104, Sample 547A-60-2, 0-2 cm; note high morphological variability of $X$. ceratioides shown in Figs. 9-12. 